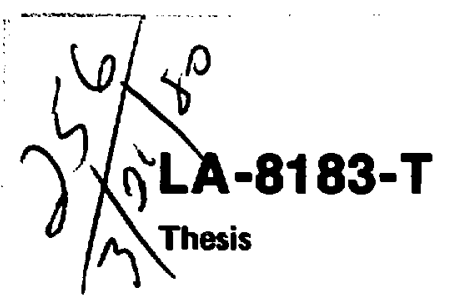

Radium-226 in Vegetation and Substrates at Inactive Uranium Mill Sites

\section{MASTER}

$\frac{\pi}{\text { 는 }}$

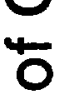

章

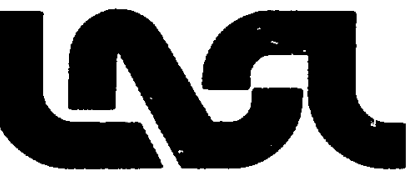

LOS ALAMOS SCIENTIFIC LABORATORY

Post Office Box 1663 Los Alamos. New Mexico 87545 


\title{
Radium-226 in Vegetation and Substrates at Inactive Uranium Mill Sites
}

\author{
Mary Lynn Marple
}




\section{CONTENTS}

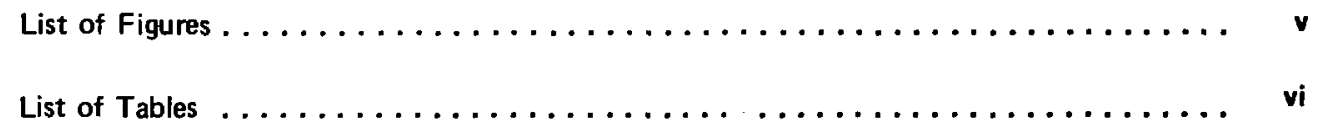

Abstract $\quad \ldots \ldots \ldots \ldots \ldots \ldots \ldots \ldots \ldots \ldots \ldots \ldots \ldots \ldots \ldots \ldots \ldots$ viii

Introduction $\quad \ldots \ldots \ldots \ldots \ldots \ldots \ldots \ldots \ldots \ldots \ldots \ldots \ldots \ldots \ldots \ldots \ldots \ldots$

Materials and Methods $\ldots \ldots \ldots \ldots \ldots \ldots \ldots \ldots \ldots \ldots \ldots \ldots \ldots \ldots \ldots$

Results and Discussion $\ldots \ldots \ldots \ldots \ldots \ldots \ldots \ldots \ldots \ldots \ldots \ldots \ldots$

Evaluation of Cleaning Methods $\ldots \ldots \ldots \ldots \ldots \ldots \ldots \ldots \ldots \ldots \ldots \ldots$

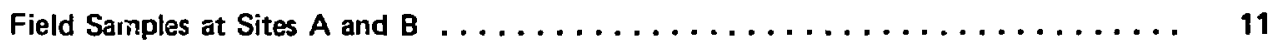

Survey of Inactive Uranium Mill Sites in the Four Corners Region .......... 24

Greenhouse Experiment $\ldots \ldots \ldots \ldots \ldots \ldots \ldots \ldots \ldots \ldots \ldots \ldots \ldots \ldots \ldots$

Summary and Conclusions $\quad \ldots \ldots \ldots \ldots \ldots \ldots \ldots \ldots \ldots \ldots \ldots \ldots \ldots \ldots \ldots \ldots$

Acknowledgments $\ldots \ldots \ldots \ldots \ldots \ldots \ldots \ldots \ldots \ldots \ldots \ldots \ldots \ldots \ldots \ldots \ldots$

Selected Bibliography $\ldots \ldots \ldots \ldots \ldots \ldots \ldots \ldots \ldots \ldots \ldots \ldots \ldots \ldots \ldots \ldots .41$

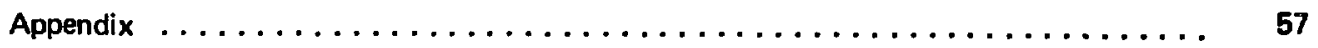




\section{LIST OF FIGURES}

Figure

Page

1. Map (made from aerial photographs) of the tailings pile at site $\mathbf{A}$

2. Radium-226 activity in aboveground shoots of three species from two substrates, tailings pond (346 $\mathrm{pCi} / \mathrm{g})$ and tailings sand $(160 \mathrm{pCi} / \mathrm{g})$,

at site A during two growing seasons

3. Radium-226 activity at three substrate depths from different locations at sites $A$ and $B$

4. Radium:calcium ratio in plant shoots as a power function of that ratio in the substrate

5. Summary of mean radium-226 activity in different plant species wherever they occurred on covered and uncovered tailings piles at several inactive uranium mill sites in the Four Corners Region $\ldots \ldots \ldots \ldots \ldots \ldots 28$

6. Diagram of tailings and control treatments from greenhouse experiment ... 30

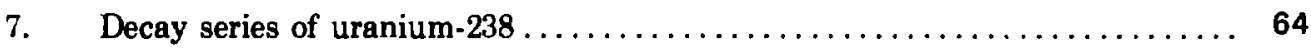




\section{LIST OF TABLES}

Table

1. Radium-226 activity, aluminum concentration, and titanium concentration in substrates from different locations at site $\mathrm{A}$ and adjacent rangeland .....

2. Radium-226 activity, aluminum concentration, and titanium concentration in plant samples cleaned by three different methods

3. Comparison of total radium-226 activity of plant sample with activity within plant parts for air-cleaned samples

4. Radium-226 activity of aboveground shoots of Sitanion hystrix and associated substrates from tailings pile at Site $\mathrm{A}$ and adjacent rangeland during two growing seasons

5. Radium-226 activity of aboveground shoots of four species and associated substrates from site $B$ and an adjacent area during $1977 \ldots \ldots \ldots \ldots \ldots$

6. Radium-226 activity of aboveground shoots of Kochia scoparia and associated tailings from different locations at Site B

7. Radium-226 activity in aboveground shoots of several plant species and associated substrates (both extractable and total)

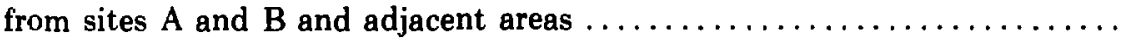

8. Radium-226 activity in different parts of several plant species from

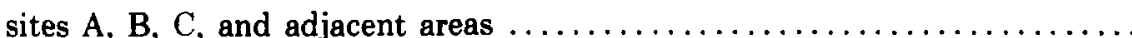

9. Radium-226 activity, calcium concentration, and radium:caclium ratio in aboveground shoots and associated substrates (both total and extractable) from sites $\mathrm{A}$ and $\mathrm{B}$ and adjacent rangeland $\ldots \ldots \ldots \ldots \ldots \ldots \ldots \ldots$

10. Radium-226 activity, calcium concentration, and radium:calcium ratio in aboveground shoots and associated substrates (bulk and fines)

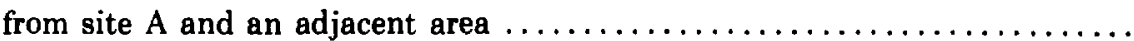

11. Mean radium-226 activity in aboveground shoots from several plant species, tailings (both total and extractable), and soil overburdens (where present) from inactive uranium mill sites in the Four Corners Region ..............

12. Radium-226 activity in aboveground shoots of nir.a plant species from inactive uranium mill sites in the Four Corners Region ................

13. Radium-226 activity of substrates from greenhouse experiment $\ldots \ldots \ldots \ldots$ 
14. Comparison of extractable radium-226 activity as calculated from extracts made by different methods on tailings from site $A$ used in greenhouse experiment . 31

15. Aboveground biomass and radium-226 activity of Sporobolus airoides and Atriplex canescens grown in control soils and tailings in greenhouse experiment 33

16. Radium-226 activity, calcium concentration, and radium:calcium ratio in soils (both total and leachable) and aboveground shoots from greenhouse experiment 34

17. Comparison of aboveground biomass and radium-226 activity of Atriplex canescens in three treatmerts from the greenhouse experiment $\ldots \ldots \ldots \ldots \ldots 35$

18. Comparison of mean radium-226 activity in aboveground shoots and associated substrates from field sites and greenhouse experiment 


\title{
RADIUM-226 IN VEGETATION AND SUBSTRATES AT INACTIVE URANIUM MILL SITES
}

by

Mary Lynn Marple

\begin{abstract}
The uptake and translocation of contaminants from uranium mill lailings piles and ot her similar wastes (such as uranium mine spoils and phosphate mine tailings) could be an important transport mechanism of these contaminants into the environment. Radium-226 is of particular concern due to its long half-life and its ability to be accumulated in bone. This work is the study of the content of radium-226 in plants growing on inactive uranium mill :ailings sites in the Four Corners Region of the southwestern United States and in planls: grown under greenhouse conditions with minimal surficial contamination.

Field plant samples and associated substrates were analyzed from two carbonate tailings sites in the (irants Mineral Belt of New Mexico. Radium activities in air-cleaned samples ranged $1 \mathrm{rom} ; 10: 368 \mathrm{p(ci/g}$ (dry weight) depending on species and location: activities in plants growing on local soils averaged $1.0 \mathrm{pCi} / \mathrm{g}$. The tailings and local soils contain 14()$-i f(1)$ $p\left({ }^{\circ} \mathrm{i} / \mathrm{g}\right.$ and $2.1 \mathrm{p}(\mathrm{i} / \mathrm{g}$. respectively. An evaluation of cleaning methuds on selected samples shuwed that from 17 to $79 \%$ of the radium activity measured in air-cleaned samples was due to surficial contamination. which varied with species and location. A survey of 18 inactive uranium mill sites in the Four Corners Region was performed. Radium activity in plant tissus . irom nine species ranged from 2 to $210 \mathrm{pCi} / \mathrm{g}$ on bare tailings and from 0.3 to $3010 \mathrm{pC} \mathrm{Ci} / \mathrm{g} \mathrm{on}$ covered tailings. The radium content in most of the soil overburdens on the covered lailings: piles was 10 to $17 \mathrm{pCi} / \mathrm{g}$.

An experiment was performed to measure radium-226 uptake hy two species grow'll on tailings covered with a shallow $(5 \mathrm{~cm})$ soil layer. A grass, Sporobolus airoides (alkali sacat on! and a shrub. Atriplex canescers (four-wing salthush), were studied. The tailings were a mixture of sands and slimes from a carbonate pile. The tailings treat ments were plants grown in a soil cover over tailings; the controls were plants grown only in soil. Three soil types. dune sand. (lay loam, and loam, were used. The radium activity of the plant tissue from the tail. ings treatment compared to that of the appropriate control was 1 to 19 times greater for the yrass and +1027 times greater for the shrub.
\end{abstract}




\section{INTRODUCTION}

Radium:226 has been the focus of many studies since its discovery and isolation from pitchblende by Marie Curie. First, attention focused on its effects on the processes of cells and its medical uses (Silberstein 1950). Some early studies focused on the effects of radium on plant yield and on its uptake (Lepape and Trannoy 1934a and 1934b; Drobkov 1937; Baranov 1939). Later the role of radium in the natural environment and its contribution to the natural radiation dose to man were investigated. Diverse studies of natural raaium levels in soils, land plants, and foods reported soil activities of 0.5 to $1.5 \mathrm{pCi} / \mathrm{g}$ in most locations and food contents of $0.01 \mathrm{pCi} / \mathrm{g}$ dry weight or less (Bowen 1966; Brooks 1972). Numerous investigations in the Soviet Union described the natural radiation environment in both normal and enhanced radium regions and its influence on living organisms (Aleksakhin 1971). A historical literature review of studies on the biological effects of radium, its role in the natural radiation environment, and its content in soils, plants, and foods is presented in the Appendix. Increases in radiation in the environment from energy sources and from the use of artificial products, such as phosphate fertilizers, have been termed "technologically enhanced natural radiation" (Gesell and Prichard 1975) and have been the focus of many recent studies. Elevated radium contents (by a factor of 10 or more) have been reported for coal ash (Eisenbud and Petrow 1964) and for soils and tailings from areas of phosphate mining (Roessler et al. 1980). This study will address the uptake and translocation of radium-2'26 by plants at inactive uranium mill sites in the southwestern United States.

Under contract to the Atomic Energy Commission, several companies developed uranium mills in the western United States during the 1940s and 1950s. At first, much experimentation was performed with milling processes for the extraction and concentration of uranium as a semi-refined product, yellowcake. Basically three processes, acid leach, alkaline (carbonate) leach, and upgrading were used. The ore was first crushed and ground to less than $0.9 \mathrm{~mm}$ ( $-28 \mathrm{mesh}$ ) for most acid leach processes and to less than $0.1 \mathrm{~mm}$ ( $-200 \mathrm{mesh})$ for typical alkaline leach and upgrading processes. In an acid process, the ground ore was leached with sulfuric acid; in an alkaline procéss, the ore was leached with sodium carbonate and bicarbonate. Only 1 to $3 \%$ of the radium-226 in the ores was dissolved in acid and carbonate leaching circuits, respectively. After leaching, liquid-solid separations were executed, with the solids becoming the tailings and being slurried to ponds. The pregnant leach solutions were concentrated and purified, and then uranium was precipitated from them. Some barren leach solutions were also discharged to the tailings pond. In an upgrader plant, a slime concentrate was produced from coarse sandstone ores for further processing in an acid or alkaline circuit. The concentrate was produced by size classification of the ground ore and by acid leaching of the coarse ore fraction with the slimes being separated from the slurry; the coarse sand fraction of the ore was disposed of in the tailings pile (Merritt 1971). Some uranium ores had sufficient vanadium contents to justify its extraction; vanadium was separated from the uranium after leaching.

Much attention has focused on radium as an environmental contaminant from uranium mills both in the Soviet Union (Bakhurov, Lutsenko, and Shashkina 1965) and the United States (Beverly 1968; Clark 1974). The possibility of radiation in plant and soil samples from a revegetated mill tailings pile was examined, but no evidence was found (U.S. Atomic Energy Commission 1963 and 1966). Radium contamination has also been studied downstream from a uranium mine; the roots and stems of plants growing close to the mine 
had 20 and 2 times the corresponding activity of those growing far from the mine (Parsont 1967). The radium content of foods from a uranium-producing area in India was also documented (Iyengar and Markose 1970); an impact up to $3 \mathrm{~km}$ from the site was observed (Kamath, Iyengar, and Bhat 1974). Radiation surveys were conducted at various uranium mill sites (Snelling 1970 and 1971) and particulates at three sites were compared (Breslin and Glauberman 1970). Radium released from a uranium mill in Australia was seen to remain in the surface soil (Watson 1975). Similar studies have been conducted for areas of elevated uranium concentrations (Hanson 1980).

In order to reduce the environmental impact of mill tailings piles, a program of revegetation of inactive piles was undertaken. Twenty-one inactive sites, of which six have not been stabilized, were studied (U.S. Atomic Energy Commission 1974). Many modifications were seen to be necessary to achieve successful vegetative establishment; these included the amelioration of $\mathrm{pH}$ and salinity and the addition of nutrients, particularly nitrogen, and moisture (Donovan, Felder, and Rogers 1976). The inhibition of growth, the uptake of heavy metals, and their subsequent release into the atmosphere (Gadgil 1969; Beauford, Barber, and Barringer 1977) were also concerns for revegetation programs. The entry of radium into food chains through plant uptake caused particular concern (Whicker 1978) since radium was evaluated to be one of the major hazards (with radon) from uranium mining and milling wastes (Schiager 1977). Although some environmental impact of tailings piles could be reduced by revegetation, the problems of radon emanation and contamination of food chains with radium, uranium, and trace elements were still concerns (Carter 1978). Emanation of radon-222 from leaf surfaces was greater than that from normal soils (Pearson and Jones 1966). The contamisicints present in mill tailings and other solid wastes could inhibit plant growth (Bittel, Fourcade, and Zettwoog 1978). In Canada, uranium tailings have been revegetated with grasses, legumes, and trees using additions of limestone and fertilizer (Murray and Moffett 1977; Moffett and Tellier 1978; Murray 1978), but the radium activity of the grasses was found to be 4 to $7 \mathrm{pCi} / \mathrm{g}$ compared to background levels of $0.2 \mathrm{pCi} / \mathrm{g}$ (Moffett and Tellier 1977; Moffett et al. 1978). Grasses growing on sludged tailings had activities of 10 to 55 $\mathrm{pCi} / \mathrm{g}$ (Schmidtke et al. 1978). Similar results were reported for tailings piles in the Four Corners Region (Kelley, Potter, and Marple 1978). Problems of uptake and contamination of plants by toxic elements growing on uranium spoil areas in New Mexico have been identified (Kelley 1979). Radium in the environment was also studied for decontamination of former radium-processing sites (Voelker 1978); the most limiting pathway was concluded to be radon-222 concentration in buildings but the food chain pathway was also considered (Healy and Rolgers 1978). Radium uptake by biota in an area of wind-dispersed tailings near a uranium mill has been studied; in flants, an acropetal gradient and a decrease in activity of one to two orders of magnitude bet.., een June and September were observed (Kotsch 1977). Similar studies in the same area showed radium activities of several plant species from 5 to $100 \mathrm{pCi} / \mathrm{g}$ dry weight in the vicinity of uranium mines and mill in Wyoming (Winsor and Stahlecker 1974; Winsor and Whicker 1975). Elevated alpha activities were reported in plants from a mine site (Kennington and Doerges 1978). As part of a generic environmental impact statement for uranium milling, radium and other nuclides were measured in flora and fauna near tailings piles; grass and tamarisk growing on tailings had activities more than 20 times control levels (Holtzman et al. 1979). The soil and plant activities from a natural area and from man-enhanced areas (due to the release of uranium ore processing products) in the Soviec Union were studiea; enhanced soil activities were 10 to 1000 times natural ones and plant radioactivity was as high $\approx s 19 \mathrm{pCi} / \mathrm{g}$ in comparison to a natural activity of less than 2 $\mathrm{pCi} / \mathrm{g}$ (Titaeva et al. 1980). Thus, the release of radium into the environment and its bioavailability has been documented in many areas of uranium production.

The uptake of radium by native and naturalized species growing on 21 inactive uranium 
mill tailings piles in the southwestern United States could be an important transport mechanism in the environment for this contaminant. Radium uptake by many species of plants has been described in other areas of enriched ura:ium and thorium. Radium is often technologically enhanced due to coal, phosphates, and other materials. The objectives of this study are to measure the uptake and translocation of radium to aboveground parts of plants growing in uranium mill tailings, to compare these results with plants grown in local soil, to compare radium uptake in different species and at different locations, and to apply the estimates of radium uptake to the assessment of plant uptake as a transport mechanism of radium in the environment.

The assimilation of radium will be measured by the determination of radium-226 activity in plant samples and associated substrates from two inactive uranium mill tailings piles and by the estimation of the contribution of surficial contamination by particulates to the radium activity of the plant samples. Local soils and plants growing in thein will serve as a baseline for comparison. Several native and naturalized species of different growth habits will be compared. A survey of inactive uranium mill sites will establish variations in uptake under different growth conditions and from different tailings materials. These field results will be compared with uptake by plants grown under controlled experimental conditions in a greenhouse. The results of radium uptake by diverse species will be applicable in estimating the bioavailability of radium from wastes from uranium mining and milling and from other energy technologies and the potential impact on the food chain in arid ecosystems. 


\section{MATERIALS AND METHODS}

Plants growing naturally on two inactive uranium mill sites in the Grants Mineral Belt, west of Albuquerque, New Mexico, were the source of field samples. This region has been the locrition of intensive uranium mining and milling activity for almost 30 years and over $50 \%$ of the known uranium reserves in the United States are in this region (Perkins 1979). The region is an arid grassland with approximately $25 \mathrm{~cm}$ of precipitation annually. At both sites, the mill used an alkaline (carbonate) leaching process. At Site $A$, tailings were deposited between 1958 and 1963 and were generated in the milling of a sandstone ore. The tailings pile covers an area of 37 hectares (Purtymun, Wienke, and Dreesen 1977). Nearby are areas of water-eroded and wind-blown tailings where plants were also collected. Figure 1 is a map made from aerial photographs of Site A. At Site B, the tailings were generated from both sandstone and limestone ores and were deposited between 1953 and 1959 (Merritt 1971). The tailings cover an area of 25 hectares, of which 18 hectares had already been covered with local soil (between 5 to $50 \mathrm{~cm}$ thick) a few years before the study began. Plant samples were collected from both the bare and the covered tailings. Control plants were collected from areas of local soil within two $\mathrm{km}$ of the tailings piles.

In order to compare the levels of radium-226 in these plants with those from other tailings piles, a survey of inactive uranium mill sites (Sites $C$ through $S$ ) in the Four Corners Region was performed. This region includes parts of Arizona, Colorado, New Mexico, and Utah and is an arid region with shrub and grassland vegetation. On most tailings piles in Colorado and Utah, revegetation had been attempted by seeding with native grasses, fertilizing, and irrigating after placing a shallow $(18 \mathrm{~cm}$ ) soil cover over the tailings (Beverly 1968 ). On three piles in Colorado and one in New Mexico, revegetation was attempted on bare tailings (Donovan, Felder, and Rogers 1976).

For the grasses and forbs, field plants were collected for radium analysis by clipping at the ground level. For the shrubs, the last year's growth was collected. These samples were aircleaned (using a compressed air flow for about two minutes) after drying in paper bags in a hood. Some samples of other plant parts were also analyzed. Aboveground parts, such as fruits and stems, were air-cleaned, but roots were washed in a sonic water bath for one hour using doubly distilled water. All samples were then oven-dried at $100^{\circ} \mathrm{C}$ for 48 hours and ashed at $450^{\circ} \mathrm{C}$ for 48 hours. The ashed samples were sealed in half-ounce seamless steel cans for radium-226 analysis. Samples of aboveground shoots from the greenhouse experiment were clipped at the top of the perlite mulch and were rinsed twice with distilled water in plastic bags. After blotting on paper towels, they were air-dried in paper bags for three to four days and ground in a Wiley mill with a 20 -mesh screen. The ground samples were sealed in half-ounce cans for analysis.

The field substrates (soil or tailings) in which the plants grew were collected from the top five centimeters at the base of the plant. At selected locations at Sites $A$ and $B$, the substrate was cored using a Giddings soil sampler (with a diameter of $3 \mathrm{~cm}$ ); the cores were divided ints the uppermost five $\mathrm{cm}$ and two subsequent $10 \mathrm{~cm}$ increments. Substrates used in the greenhouse experiment were also analyzed. All substrate samples were air-dried in a hood and sealed in two-ounce seamless steel cans. Also, on selected samples from Sites A and B and from the survey of inactive sites, the radium-226 activity in ammonium acetate ( $\mathrm{pH} \mathrm{5.2)} \mathrm{ex-}$ tracts was measured. A method based on Black (1965) was used for the extraction procedure (Kelley 1979) and $50 \mathrm{~m} \ell$ of the solution was sealed in a low-form Pyrex weighing bottle for 
analysis.

Gamma spectroscopy has been shown to be a quick and non-destructive method of analysis for measuring radium-226(Powers, Turnage, and Kanipe 1980).Dry vegetation and soil samples were encapsulated in steel cans for this method. The lids of the filled cans were sealed with plastic tape and sprayed with an acrylic sealant to prevent loss of radon-222 from the sample. After sealing, at least three weeks elapsed before counting to attain secular equilibrium between radium-226 and its gamma-emitting daughters. Kirchmann and Berino (1965) reported that after 22 days, the ratio of bismuth-214 to radium-226 in both roots and aboveground biomass of Pisum sativum was 0.98 . Canadian soil standards were encapsulated in steel cans as described above for use in calibration. Vegetation standards were prepared from NBS standard reference material diluted to the appropriate concentration. Either dried or ashed plant material with a low abundance of radium-226 were spiked with the standard solution. After drying, the plant materials were encapsulated in half-ounce steel cans. For liquid samples, a dilution of the NBS standard was sealed in a glass sample container. A gamma-ray spectrometer with four solid state $\mathrm{Ge}(\mathrm{Li})$ detectors which were mixed into a single channel analyzer for data acquisition was used to measure the $609-\mathrm{keV}$ gamma rays from bismuth-214, a decay product in the uranium-238 decay series (see Figure 7 in the Appendix). Each detector was allotted a separate portion of the analyzer memory,. The counting efficiency of these detectors ranged from 13 to $22 \%$ (relative to a $3 \times 3 \mathrm{NaI}(\mathrm{T} \ell$ ) detector as measured by IEEE standard test 325). Standards with known activities of radium-226 were counted to obtain an absolute counting efficiency for each detector. Counting times for the encapsulated samples were commensurate with the radium activity. The detection limit for a large sample ( $70 \mathrm{~g}$ of substrate) was approximately $35 \mathrm{pCi}$ of Ra-226 with a counting period of one hour or $9 \mathrm{pCi}$ for 16 hours. Low level substrate and vegetation samples were counted for 12 hoúrs; high level samples were counted until approximately 5000 counts had been recorded (from 15 minutes to 3 hours). An analytical uncertainty was calculated using counting statistics (approximately the reciprocal of the square root of total number of counts) and the variation in the efficiencies from the standards $(\sim 10 \%)$. The uncertainty was $10 \%$ for high level samples and $20 \%$ or more for low level samples (depending on the number of counts). The sample counting data were transferred via magnetic tape to a PDP-11 minicomputer where the area of the bismuth-214 peak was determined. The abundance of radium-226 was calculated using the ratio of measured activities between the sample and the appropriate standard.

An approximate t-test was used to test the equality of means of two samples whose variances are assumed to be unequal; a special case of the $t$-test was used for comparison of a single observation with the mean of a sample (Sokal and Rohlf 1969). Analysis of variance and a non-parametric test were used in testing the statistical significance of differences between treatments in the greenhouse experiment. Single classifications anovas with unequal sample sizes and with two groups with equal sample sizes were used (Sokal and Rohlf 1969). The Mann-Whitney U-test (also known as the Wilcoxon two-sample test) was employed in testing the hypothesis that two samples came from populations having the same distribution (Sokal and Rohlf 1969). 


\section{Evaluation of Cleaning Methods}

A study was undertaken to determine the effectiveness of cleaning methods for vegetative samples and to estimate the portion of the activity of radium-226 in a plant sample which is attributable to plant uptake as opposed to contamination due to the presence of substrate particles on the surface of the plant tissue. The plant samples were collected from Site $A$ and from a nearby area in October 1977. The samples were as follows: (1) leaves and fruits of a shrub, Atriplex canescens (four-wing saltbush) from tailings sand and from local soil; (2) a perennial grass, Sitanion hystrix (bottlebrush squirreltail), from a disturbed area off the southwest corner of the tailings piles (see Figure 1), where tailings slimss and loam soil formed the substrate; and (3) an annual forb, Kochia scoparia (summer-cypress), from the tailings pile at the west end of the intermittent pond (see Figure 1). A substrate sample was collected from the top $5 \mathrm{~cm}$ at the base of each plant. After a bulk sample had been set aside for analysis, the substrate samples were sieved using a sonic sifter to produce a dry fines fraction $(<53 \mu \mathrm{m})$. Since the fine particles often form aggregates upon wetting and drying (Schwendiman et al. 1979) and many aggregates remained after sonic sieving, the dry fines may not have been truly representative of the fine fraction. So, wet sieving using sodium hypophosphate (1N) as a dispersing agent was also done to produce the "wet fines" samples. The cleaning methods for the plant samples were as follows: (1) none; (2) air-cleaned:cleaning the plant sample heli between two brass sieves ( 20 mesh) with a compressed air stream for approximately two minutes; and (3) water-cleaned: cleaning the plant sample in a sonic water

Table 1. Radium-226 activity (pCi/g dry weight), aluminum concentration ${ }^{1}(\mathrm{mg} / \mathrm{g})$, and titanium concentration ${ }^{1}(\mathrm{ppm})$ in substrates ${ }^{2}$ from different locations at site $A$ and adjacent rangeland

\begin{tabular}{|c|c|c|c|c|c|}
\hline \multirow[b]{2}{*}{ Substrate } & \multicolumn{3}{|c|}{ Radium-226 Activity } & \multirow{2}{*}{$\begin{array}{c}\text { Aluminum } \\
\text { in Dry Fines }\end{array}$} & \multirow{2}{*}{$\begin{array}{c}\text { Titanium } \\
\text { in Dry Fines }\end{array}$} \\
\hline & Bulk & Wet Fines & Dry Fines & & \\
\hline Tailings and soil & $440 \pm 35$ & $440 \pm 44$ & $370 \pm 13$ & $90 \pm 9$ & $1060 \pm 106$ \\
\hline Tailings pond & $410 \pm 35$ & $850 \pm 78$ & $640 \pm 11$ & $34 \pm 3$ & $1280 \pm 50$ \\
\hline Tailings sand & $110 \pm 10$ & $550 \pm 18$ & $240 \pm 9$ & $35 \pm 4$ & $660 \pm 66$ \\
\hline Local soil & $2.6 \pm 0.3$ & $81 \pm 5$ & $26 \pm 3$ & $60 \pm 6$ & $1300 \pm 130$ \\
\hline
\end{tabular}

Results of one measurement \pm analytical uncertainty given.

Three size fractions of substrates: (1) bulk - all fractions; (2) wet fines - fraction $\langle 53 \mu \mathrm{m}$ produced by sieving after dispersal in sodium hypophosphate solution; and (3) dry fines - fraction $<53 \mu \mathrm{m}$ produced by sonically sieving dry samples. 


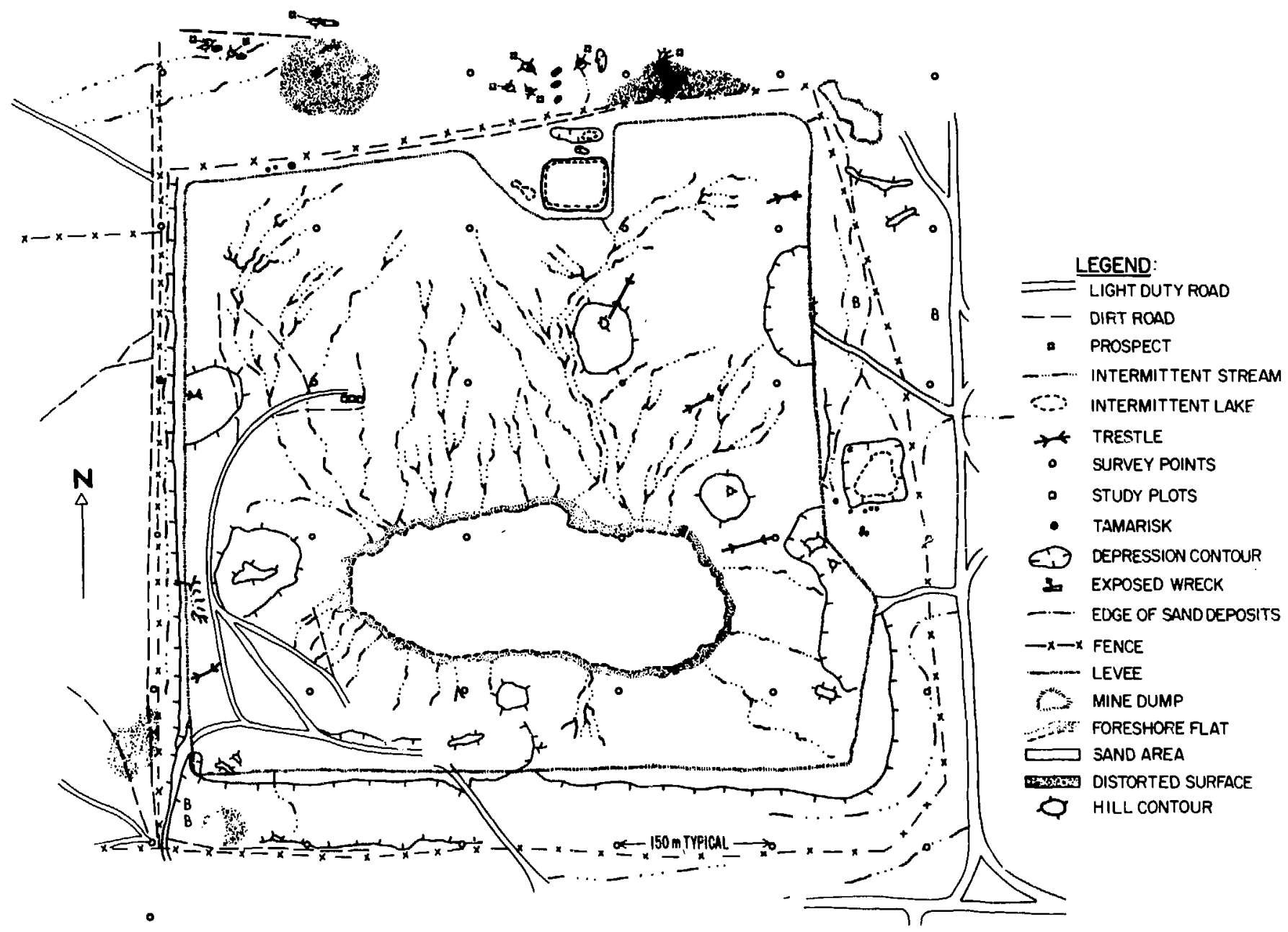

Figure 1. Map (made from aerial photographs) of the tailings pile at site A showing tailings pond (intermittent lake). 
bath for one hour, using doubly distilled water. Plant and substrate samples were analyzed for radium activity by the encapsulation technique described earlier, for aluminum by instrumental therrial neutron activation analysis, and for titanium by flame atomic absorption analysis. Aluminum and titanium were used as indicators cf contamination, so all aluminum or titanium measured in plant samples was assumed to be due to surficial contamination. Aluminum is absorbed only from acid substrates (Bowen 1966), so uptake of aluminum from these alkaline substrates ( $\mathrm{pH} 8$ to 9) should be quite negligible. Bowen (1966) reported that land plants contain very little titanium (1 ppm). If the plants did absorb either of these elements (Robinson and Edgington 1945), it would indicate that these estimates of surficial contamination are upper limits.

The results of substrate analyses are shown in Table 1 . These substrates had typical aluminum contents but low titanium contents (by a factor of four) compared to most soils (Bowen 1966). The wet fines had more radium than the dry fines by a factor of 1.2 to 5.0. T3e results of the analyses of the piant samples are shown in Table 2. The aluminum ancitanium concentrations in the dry fines were used in calculations of the mass of particulates on the plant surface based on the total aluminum and titanium concentrations in the plant samples because a previous study showed most particles in foliage contamination had diameters $<44 \mu \mathrm{m}$ (Romney et al. 1963). The mass of particulates was then used to calculate the percen. tage of radium activity on the surface of the plant tissue using the substrate activities given in Table 1 . The activity of radium truly within the plant tissue was calculated using aluminum and titanium separately and then means were calculated. The calculations were performed as follows: let $\mathrm{x}=\mathrm{Al}$ or $\mathrm{Ti}$

$$
\begin{aligned}
& p=\text { plant sample } \\
& W=\text { dry weight of plant sample } \\
& s=\text { substrate concentration in dry fines fraction } \\
& {[x]_{p}\left(\frac{g}{g}\right) \times W(g)=x_{p}(g)} \\
& \frac{x_{p}(g)}{[x]_{0}(g / g)}=g \text { of substrate on plant }
\end{aligned}
$$

$g$ of substrate on plant $\times[\mathrm{Ra}]_{\bullet}(\mathrm{pCi} / \mathrm{g})=\mathrm{Ra}(\mathrm{pCi})$ on surface

$[R a]_{p} \times W=R a(p C i)$ on surface and in tissue

Fraction of $R a$ in tissue $=\left(1-\frac{R a \text { on surface }}{R a \text { on surface and in tissue }}\right)$

True $R a=($ Fraction of $R a$ in tissue $) \times$ total radium

The contributions of surficial contamination to total radium activity of the plant samples ranged from 15 to $79 \%$. These estimates may be high due to the radium activities of the dry. fines used. Studies of particle creep and saltation at Site $A$ indicate that the particulates on the tailings piles collected up to $75 \mathrm{~cm}$ above the ground level had an average radium activity 
Table 2. Radium-226 activity' (pCi/s dry weight), aluminum concentration' (mr/ $/ \mathrm{g}$ ), and titanium concentration' ( $(\mathrm{ppm})$ in plant eamples cleaned by three different mothods

\begin{tabular}{|c|c|c|c|c|c|c|c|c|c|c|c|c|}
\hline \multirow[b]{2}{*}{ Specien } & \multirow[b]{2}{*}{ Parts } & \multirow[b]{2}{*}{ Subatrate } & \multirow{2}{*}{$\begin{array}{l}\text { Cleunins } \\
\text { Mothod } \\
\end{array}$} & \multirow{2}{*}{$\begin{array}{c}\text { Total } \\
\text { Re-226 } \\
\end{array}$} & \multirow[b]{2}{*}{ Aluminum } & \multirow[b]{2}{*}{ Titenium } & \multicolumn{3}{|c|}{ Percentage on Surface } & \multicolumn{3}{|c|}{ Ra-226 within Plent Parts } \\
\hline & & & & & & & Al & $\mathbf{T H}$ & Menn & $\mathbf{A l}$ & $\mathbf{T}$ & Mean \\
\hline $\begin{array}{l}\text { Sitanion } \\
\text { hyatrix }\end{array}$ & lenves & $\begin{array}{l}\text { tailings } \\
\text { and soil }\end{array}$ & $\begin{array}{l}\text { none } \\
\text { air } \\
\text { water }\end{array}$ & $\begin{array}{r}121 \pm 5 \\
110 \pm 4 \\
92 \pm 8\end{array}$ & $\begin{array}{l}2.0 \pm 0.2 \\
i .4 \pm 0.2 \\
1.4 \pm 0.1\end{array}$ & $\begin{array}{c}115 \pm 12 \\
86 \pm 9 \\
53 \pm 5\end{array}$ & $\begin{array}{r}10 \\
7 \\
9\end{array}$ & $\begin{array}{l}33 \\
27 \\
20\end{array}$ & $\begin{array}{l}21 \pm 16 \\
17 \pm 14 \\
15 \pm 8\end{array}$ & $\begin{array}{r}109 \\
102 \\
84\end{array}$ & $\begin{array}{l}81 \\
80 \\
74\end{array}$ & $\begin{array}{l}95 \pm 10 \\
91 \pm 6 \\
79 \pm 7\end{array}$ \\
\hline $\begin{array}{l}\text { Kochia } \\
\text { ecoparia }\end{array}$ & $\begin{array}{l}\text { leaves } \\
\text { and stems }\end{array}$ & $\begin{array}{l}\text { tailing } \\
\text { pond }\end{array}$ & $\begin{array}{l}\text { none } \\
\text { air } \\
\text { water }\end{array}$ & $\begin{array}{c}184 \pm 11 \\
112 \pm 23 \\
34 \pm 6\end{array}$ & $\begin{array}{c}7.4 \pm 0.4 \\
1.9 \pm 0.1 \\
0.6 \pm 0.1\end{array}$ & $\begin{array}{c}210 \pm 4 \\
86 \pm 8 \\
11 \pm 1\end{array}$ & $\begin{array}{l}66 \pm 1 \\
28 \pm 4 \\
29 \pm 1\end{array}$ & $\begin{array}{l}58 \pm 5 \\
40 \pm 12 \\
17 \pm 6\end{array}$ & $\begin{array}{l}62 \pm 6 \\
34 \pm 8 \\
23 \pm 8\end{array}$ & $\begin{array}{l}63 \pm 6 \\
80 \pm 20 \\
23 \pm 4\end{array}$ & $\begin{array}{l}78 \pm 13 \\
69 \pm 27 \\
28 \pm 7\end{array}$ & $\begin{array}{l}70 \pm 11 \\
74 \pm 8 \\
26 \pm 4\end{array}$ \\
\hline $\begin{array}{l}\text { Atriplex } \\
\text { canescens }\end{array}$ & leaver & $\begin{array}{l}\text { tailings } \\
\text { eand }\end{array}$ & $\begin{array}{l}\text { none } \\
\text { air } \\
\text { water }\end{array}$ & $\begin{array}{l}6.1 \pm 0.3 \\
4.9 \pm 0.5 \\
7.6 \pm 0.8\end{array}$ & $\begin{array}{l}0.5 \pm 0.1 \\
0.4 \pm 0.1 \\
0.2 . \pm 0.1\end{array}$ & $\begin{array}{r}24 \pm 2 \\
26 \pm 3 \\
7.7 \pm 2\end{array}$ & $\begin{array}{l}56 \\
56 \\
18\end{array}$ & $\begin{array}{r}100 \\
100 \\
37\end{array}$ & $\begin{array}{l}78 \pm 31 \\
78 \pm 31 \\
28 \pm 13\end{array}$ & $\begin{array}{l}2.7 \\
2.0 \\
6.2\end{array}$ & $\begin{array}{l}0.0 \\
0.0 \\
4.8\end{array}$ & $\begin{array}{l}1.4 \pm 1.9 \\
1.0 \pm 1.4 \\
5.5 \pm 1.0\end{array}$ \\
\hline $\begin{array}{l}\text { Atriplex } \\
\text { canescens }\end{array}$ & fruite & $\begin{array}{l}\text { tailings } \\
\text { and }\end{array}$ & $\begin{array}{l}\text { none } \\
\text { air } \\
\text { water }\end{array}$ & $\begin{array}{r}9.6 \pm 0.8 \\
10.6 \pm 0.8 \\
3.4 \pm 1.1\end{array}$ & $\begin{array}{l}0.8 \pm 0.1 \\
0.7 \pm 0.1 \\
0.4 \pm 0.1\end{array}$ & $\begin{array}{l}57 \pm 6 \\
56 \pm 6 \\
12 \pm 1\end{array}$ & $\begin{array}{l}57 \\
45 \\
14\end{array}$ & $\begin{array}{r}100 \\
100 \\
23\end{array}$ & $\begin{array}{l}79 \pm 30 \\
79 \pm 39 \\
19 \pm 6\end{array}$ & $\begin{array}{l}4.1 \\
5.8 \\
2.9\end{array}$ & $\begin{array}{l}0.0 \\
0.0 \\
2.6\end{array}$ & $\begin{array}{l}2.1 \pm 2.9 \\
2.9 \pm 4.1 \\
2.7 \pm 0.2\end{array}$ \\
\hline $\begin{array}{l}\text { Atriplex } \\
\text { caneecens }\end{array}$ & leaves & $\begin{array}{l}\text { local } \\
\text { soil }\end{array}$ & $\begin{array}{l}\text { none } \\
\text { air } \\
\text { water }\end{array}$ & $\begin{array}{r}0.80 \pm 0.4 \\
1.1 \pm 0.3 \\
0.77 \pm 0.3\end{array}$ & $\begin{array}{l}0.4 \pm 0.1 \\
0.3 \pm 0.1 \\
0.3 \pm 0.1\end{array}$ & $\begin{array}{l}22 \pm 2 \\
14 \pm 2 \\
32 \pm 3\end{array}$ & $\begin{array}{l}23 \\
13 \\
18\end{array}$ & $\begin{array}{l}59 \\
60 \\
35\end{array}$ & $\begin{array}{l}41 \pm 25 \\
37 \pm 33 \\
27 \pm 12\end{array}$ & $\begin{array}{l}0.61 \\
0.96 \\
0.63\end{array}$ & $\begin{array}{l}0.33 \\
0.71 \\
0.08\end{array}$ & $\begin{array}{l}0.6 \pm 0.2 \\
0.8 \pm 0.2 \\
0.4 \pm 0.4\end{array}$ \\
\hline $\begin{array}{l}\text { Atriplex } \\
\text { canescens }\end{array}$ & fruits & $\begin{array}{l}\text { locel } \\
\text { soil }\end{array}$ & $\begin{array}{l}\text { none } \\
\text { air } \\
\text { water }\end{array}$ & $\begin{array}{l}3.1 \pm 0.8 \\
1.2 \pm 0.1 \\
0.6 \pm 0.2\end{array}$ & $\begin{array}{l}0.9 \pm 0.1 \\
0.6 \pm 0.1 \\
0.6 \pm 0.1\end{array}$ & $\begin{array}{l}86 \pm 9 \\
54 \pm 5 \\
40 \pm 2\end{array}$ & $\begin{array}{l}14 \\
23 \\
50\end{array}$ & $\begin{array}{r}97 \\
90 \\
100\end{array}$ & $\begin{array}{l}56 \pm 59 \\
56 \pm 47 \\
75 \pm 36\end{array}$ & $\begin{array}{l}2.68 \\
0.92 \\
0.28\end{array}$ & $\begin{array}{l}1.25 \\
0.04 \\
0.00\end{array}$ & $\begin{array}{l}2.0 \pm 1.0 \\
0.5 \pm 0.6 \\
0.1 \pm 0.2\end{array}$ \\
\hline
\end{tabular}

'Results of one measurement \pm analytical uncertainty for Sitanion and Atriplex; mean of two measurements \pm one atandard deviation for Kochia. 
of $200 \mathrm{pCi} / \mathrm{g} ; 32 \%$ of the particulates were $<100 \mu \mathrm{m}$ in gize and contained $350 \mathrm{pCi} / \mathrm{g}$ of radium (Dreesen and Marple, unpublished data, 1978). In contrast, the average radium activity of the particulates near the southwestern corner of the tailings pile was $100 \mathrm{pCi} / \mathrm{g}$ with $10 \%$ fines $(<53 \mu \mathrm{m})$ (Dreesen and Marple, unpublished data, 1978). Because the activities in the dry fines were greater than those for the particulates desiribed above, these calculations could overestimate the percentage of radium activity on the surface by as much as $250 \%$.

Comparison of species in Table 2 showed variation between plant species in total radium activity and surficial contamination. For cultivated plants, surficial contamination increased with the presence of hairs and glands (Romney at al. 1963). The grass had higher radium content within the tissues, possibly due to higher bulk substrate concentration, and less surficial contamination compared to the frrb. Surficial contamination for the forb was probably greater due to its pilose leaves (Harrington 1964) and to its location, where the mass and activity of particulates moved by creep and saltation were larger, as described earlier. The shrub growing on tailings had lower total radium activity by a factor of ten than either the grass or the forb, probably because of the low bulk radium activity of the substrate. Its surficial contamination was large compared to the low level of the plant tissues due to the high activity of the dry fines at that location compared to the bulk activity and to scaly and glandular surface of the leaves (Harrington 1964). The control shrub hed intermediate levels of surface contamination and had less radium activity within the plant tissues by a factor of 1.3 to $5.8 \mathrm{com}$ pared to the shrub on the tailings sand.

The effectiveness of both air-cleaning and water-cleaning was quite variable. The average reduction in the aluminum and titanium concentrations in the samples were $34 \%$ and $53 \%$ for air-cleaning and water-cleaning respectively. The water-cleaning was more offective, es-

Table 3. Comparison of total radium-226 activity (pCi/g dry weight) of plant sample with activity within plant parts for air-cleaned samples

\begin{tabular}{|c|c|c|c|c|c|}
\hline \multirow[b]{2}{*}{ Species } & \multirow[b]{2}{*}{ Plant Parts } & \multirow[b]{2}{*}{ Substrate } & \multicolumn{2}{|c|}{ Activity } & \multirow[b]{2}{*}{ Percentage } \\
\hline & & & Total ${ }^{1}$ & Within' & \\
\hline Sitanion hystrix & leaves & tailings and soil & $110 \pm 4$ & $91 \pm 16$ & 83 \\
\hline Kochia scoparia & leaves and stems & tailings & $112 \pm 23$ & $74 \pm 8$ & 66 \\
\hline Atriplex canescens & leaves & tailings sand & $4.9 \pm 0.5$ & $1.0 \pm 1.4$ & 20 \\
\hline Atriplex canescens & fruits & tailings sand & $11 \pm 0.6$ & $2.9 \pm 4.1$ & 26 \\
\hline Atriplex canescens & leaves & local soil & $1.1 \pm 0.3$ & $0.8 \pm 0.2$ & 73 \\
\hline Atriplex canescens & fruits & local soil & $1.2 \pm 0.1$ & $0.5 \pm 0.6$ & 42 \\
\hline
\end{tabular}


pocially for the Atriplex samples from the tailings sand. Water-cleaning has the potential disadvantage of leaching elements from the plant tissue (Tukey et al. 1956). However, only $0.5 \%$ and $4 \%$ of calcium- 45 in squash leaves was lost by leaching for one-half and two hours respactively (Tukey, Wittwer, and Tukey 1958). Thus the leaching losses for radium, which has a chemical behavior similar to calcium, should be quite minimal. Similarly, less than $5 \%$ of the radium in Pisum sativum was usually soluble in water after leaching for 45 minutes at $90^{\circ} \mathrm{C}$ with agitation (Kirchmann, Roncucci, and Mousny 1965). Thus, these methods may be used to partially reduce surficial contamination of plant samples.

Plant samples analyzed in the intensive field study at Sites $A$ and $B$ and in the survey of inactive tailings sites were all air-cleaned. The total radium activity will be presented but the results for the air-cleaned samples from this comparison of cleaning methods may be used to predict what portion of the total radium activity measured in a plant sample reflects the content within the plant tissues. These estimates are shown in Table 3 . The proportion of the total activity measured which was within the tissues varies from 20 to $83 \%$, depending both on species and location. At tailings locations with low substrate activity and, consequently, low plant concentration of radium, the contribution of surficial contamination was greater than at locations of high substrate activity. The cleaned samples retained a noticeable amount of surficial contarnination attributed to the tenacious attachment of submicron particles. A sizeable fraction ( $>80 \%$ ) of submicron particles can be held on leaf surfaces under conditions of wind and sirnulated rainfall (Cataldo and Vaughan 1977). The percentage of total racium activity in plant samples from tailings substrates incorporated in the shoots were $83 \%$ for Sitanion, $66 \%$ for Kochia, and $20 \%$ for Atriplex. In contrast, this percentage for Atriplex from local soil was $73 \%$.

\section{Field Samples at Sites A and B}

In order to characterize levels of radium activity of plant samples growing naturally on uranium mill tailings, a survey of available species at Sites A and B was conducted. Plants were collected at Site A during 1977 and 1978. No revegetation or stabilization has been attempted at Site A. Vegetation is very sparse on the tailings piles and only a few species, mostly invading weedy species, are present. The following species were collected at the given locations from Site A: (1) the perennial grass Sitanion hystrix, which grew in a drainage channel near the southwest corner of the tailings pile (see Figure 1); (2) the annual forb Kochia scoparia, which grew at the west end of the intermittent pond on the tailings pile (see Figure 1); (3) the annual forb Salsola kali (Russian thistle), which grew both near the intermittent pond (with Kochia) and in tailings sand ( $1 \mathrm{~km}$ east of the tailings pile); and (4) the shrub Atriplex canescens which grew in the tailings sand with Salsola. Background samples of these species were collected $1.6 \mathrm{~km}$ south of the tailings pile in the surrounding blue grama-galleta grassland in which the soil is a clay loam.

The levels of radium activity in the grass and associated substrates from Site A are shown in Table 4. Levels are higher both in plants and substrates from the tailings piles as compared to local rangeland. However, the activity of the rangeland samples was greater than the worldwide background of $0.001 \mathrm{pCi} / \mathrm{g}$ (Bowen 1966). The radium activities of plant samples (Kochia, Salsola, and Atriplex) growing at the tailings pond and on tailings sand are shown in Figure 2. The substrate activities at these locations are $346 \pm 128 \mathrm{pCi} / \mathrm{g}(\mathrm{n}=5)$ and $160 \pm 30$ $\mathrm{pCi} / \mathrm{g}(\mathrm{n}=5)$ respectively; thus, the substrate at the pond had significantly higher $(\mathrm{P}<0.02)$ radium activity than the tailings sand and both had significantly greater $(\mathrm{P}<0.001$ by approximate t-test) radium content than local soil $(2.2 \pm 1.0 \mathrm{pCi} / \mathrm{g}, \mathrm{n}=9)$. Salsola growing on the tailings pond had significantly $(\mathrm{P}<0.01)$ greater mean activity $(285 \pm 65 \mathrm{pCi} / \mathrm{g}, \mathrm{n}=9)$ than the Kochia growing with it $(144 \pm 60 \mathrm{pCi} / \mathrm{g}, \mathrm{n}=6)$ and than the Salsola on the tailings sand $(73 \pm 31$ 
Table 4. Radium-226 activity ${ }^{1}$ (pCi/g dry weight) of aboveground shoots of Sitarion hyotrix and associated substrates from the tailings pile at Site $A$ and adjacent ranfoland during two growing seasons

\begin{tabular}{|c|c|c|c|c|}
\hline \multirow[b]{2}{*}{ Date } & \multicolumn{2}{|c|}{ Tailings Pile } & \multicolumn{2}{|c|}{ Rangeland } \\
\hline & Shoots & Substrate & Shoot: & Substrate \\
\hline Apr 1977 & $38 \pm 2(1)$ & $320 \pm 47(13)$ & & \\
\hline May 1977 & $75 \pm 22(2)$ & $258 \pm 59(8)$ & $0.9 \pm 0.1(1)$ & $2.5 \pm 1.8(3)$ \\
\hline Jun 1977 & $128 \pm 5(1)$ & $273 \pm 24(2)$ & $0.9 \pm 0.3(1)$ & $1.8 \pm 0.6(2)$ \\
\hline Oct 1977 & $110 \pm 4(1)$ & $440 \pm 35(1)$ & & \\
\hline Meen $^{2} 1977$ & $85 \pm 37(5)$ & $287 \pm 70(14)$ & $0.9 \pm 0.01(2)$ & $2.2 \pm 1.3(5)$ \\
\hline Apr 1978 & $104 \pm 4(1)$ & $165 \pm 17(1)$ & & \\
\hline May 1978 & $60 \pm 5(1)$ & & & \\
\hline Jun 1978 & $81 \pm 7(1)$ & $200 \pm 17(1)$ & $0.5 \pm 0.7(1)$ & $2.2 \pm 1.0(2)$ \\
\hline Nov 1978 & $221 \pm 16(1)$ & & & \\
\hline Mean 1978 & $102 \pm 91(4)$ & $183 \pm 25(2)$ & $0.5 \pm 0.7(1)$ & $2.2 \pm 1.0(2)$ \\
\hline Mean $^{2}$ 77-78 & $99=54(9)$ & $274 \pm 74(16)$ & $0.8 \pm 0.2(3)$ & $2.2 \pm 1.2(7)$ \\
\hline
\end{tabular}

\footnotetext{
${ }^{1}(n): n$ is number of samples; if $n=1$, measured value \pm analytical uncertainty; if $n>1$, mean activity \pm one standard deviation.

${ }^{2}$ Mieanss significantly different $(\mathrm{P}<0.01)$ between tailings pile and rangeland for both plant and substrate.
}

$\mathrm{pCi} / \mathrm{g}, \mathrm{n}=6)$. This Salsola from the sand also had significantly $(\mathrm{P}<0.001)$ greater radium content than the associated Atriplex $(12 \pm 6 \mathrm{pCi} / \mathrm{g}, \mathrm{n}=8)$. All of these mean radium activities for plants growing in the tailings substrates were significantly $(\mathrm{P}<0.01)$ greater than those of plants growing in local soils. The radium content in these plant samples was $1.5 \pm 1.2(n=2)$, $0.5 \pm 0.5(n=2)$, and $0.8 \pm 0.5(n=4) \mathrm{pCi} / \mathrm{g}$ for Kochia, Salsola, and Atriplex, respectively. These results are very similar to those reported for grass from tailings sand (23 pCi/g) and grass from local soil $(0.2-0.5 \mathrm{pCi} / \mathrm{g}$ ) at this site (Holtzman et al. 1979). These activities for Salsola from the tailings pond are also significantly $(\mathrm{P}<0.05)$ greater than those in Sitanion (see Table 4). If the estimates of surficial contamination from Table 3 are used here, the radium activity within the plant tissues of Sitanion, Kochia, and Atriplex are calculated to be 82,95 , and $2.4 \mathrm{pCi} / \mathrm{g}$, respectively, compared to $0.6 \mathrm{pCi} / \mathrm{g}$ in Atriplex from local soil.

Seasonal variation in the radium activity of the plant samples was inconsistent. This may be due to variable surficial contamination from seasonal winds and rains which produce changing particle creep, saltation, and splash-up. For instance, at Site $A$, the mass of particulates collected was greater by a factor of four to five in spring as compared to summer at upwind locations; the mass of particulates collected on the tailings pile was twice as great in the summer compared to the fall (Dreesen and Marple, unpublished data, 1978). Variations in surface contamination may mask seasonal trends which have been shown elsewhere. Previous results from an area downwind from a uranium mill tailings pile revealed a decrease in activity over the growing season by a factor of 10 to 100 (Kotsch 1977). This trend was observed in other studies, but was usually a smaller decrease of a factor of two or less (Vavilov, 


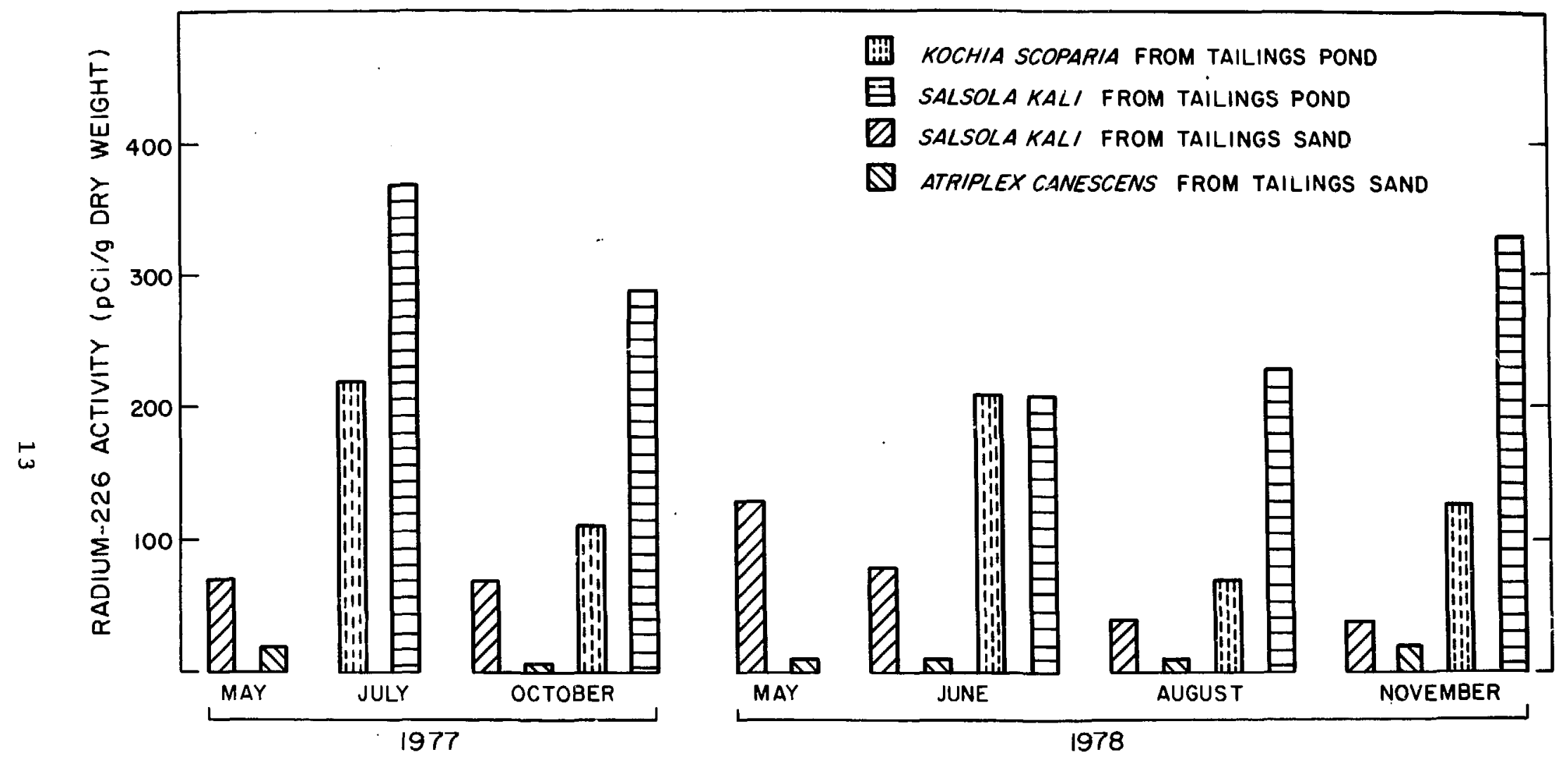

Figure 2. Radium-226 activity in aboveground shoots of three species from two substrates, tailings pond $(346 \mathrm{pCi} / \mathrm{g})$ and tailings sand $(160 \mathrm{pCi} / \mathrm{g})$, at site $\mathrm{A}$ during two growing seasons. 
Popova, and Kodaneva 1964; Vavilov et al. 1972a). A similar decrease was also reported for gross alpha and beta activity of grass (Brown 1974). Such a trend was not evident for plants growing on either tailings or soil at Site A.

Plant samples and associated substrate samples were collected for analysis at Site B during 1977. Vegetation on these tailings was less sparse than at Site A and occurred only in isolated clumps. Although a large area of the tailings had been covered with a shallow soil overburden, no attempt at revegetation had been made and natural succession was allowed to occur. The vegetation was denser on the covered tailings than on the bare tailings. The following species were collected for analysis from both the bare and covered tailings: (1) the perennial grass Sporobolus airoides (alkali sacaton); (2) the perennial grass Sitanion hystrix; (3) the annual forb Kochia scoparia; and (4) the perennial shrub Atriplex canescens. Background samples of these species were collected approximately one $\mathrm{km}$ northeast of the tailings in the surrounding grassland on clay soil.

The radium-226 activities in plants and associated substrates from Site B are shown in Table 5 . Levels in plants from the covered tailings were generally lower than those from the bare tailings, but still higher than background. These plants, except for the ehrub, were growing on areas of thin soil cover (less than $15 \mathrm{~cm}$ ) and, upon excavation, it was seen that their roots were growing into the tailings below. The mean activity of all species from he bare tailings was significantly greater than background plants $(P<0.05$ by approximate t-test). The mean activity in Sitanion $(96 \pm 10 \mathrm{pCi} / \mathrm{g}, \mathrm{n}=4)$ samples was significantly $(\mathrm{P}<0.05)$ greater than that of Sporobolus $(24 \pm 1 \mathrm{pCi} / \mathrm{g}, \mathrm{n}=1)$ and Atriplex $(11 \pm 1 \mathrm{pCi} / \mathrm{g}, \mathrm{n}=1)$ the mean activity of Kochia ( $93 \pm 57, n=3$ ) was similar to that of Sitanion. The radium content of Sitanion, Kochia, and Atriplex from the bare tailings are very similar to those measured at Site $A$. On the covered tailings, Sporobolus and Atriplex had radium activities significantly $(P<0.05)$ greater than background plants, but the activity of Sporobolus $(34 \pm 2 \mathrm{pCi} / \mathrm{g}, \mathrm{n}=1)$ was significantly $(\mathrm{P}<0.05)$ greater than that of Atriplex $(8 \pm 1 \mathrm{pCi} / \mathrm{g}, \mathrm{n}=2)$. Sitanion and Kochia had high radium content but were quite variable (coefficient of variation $85 \%$ ). Sitanion $(7.0$ $\pm 9.9 \mathrm{pCi} / \mathrm{g}, \mathrm{n}=2)$ from the covered tailings had significantly $(\mathrm{P}<0.001)$ lower radium content than from the bare tailings; the same trend $(\mathrm{P}<0.2)$ was observed for Kochia i $33 \pm 28 \mathrm{pCi} / \mathrm{g}$, $\mathrm{n}=2$ ) and Atriplex samples. The soil overburden on the covered tailings had significantly greater $(\mathrm{P}<0.01)$ radium activity $(66 \pm 21 \mathrm{pCi} / \mathrm{g}, \mathrm{n}=6)$ than the local soil from which it was taken. This could result from surface deposition of windblown tailings particulates and from capillary rise from the tailings below. The radium contents of local plants and soils from this site were similar to those described earlier at Site A. In order to investigate variations of radium-226 content within one species as related to different content in the substrate, a survey of Kochia scoparia plants from the bare tailings was performed in August 1977. The results are shown in Table 6 . The radium-226 activity in both the plant and tailings samples varied by a factor of two to three, but the relationship between plant and tailings activities is not direct. Other factors such as extractable (as opposed to ntal $^{\text {l }}$ radium content and calcium content of the tailings could be important.

In order to study further the cause of variations in radium activity of the plant samples, substrates at selected locations from Sites A and B were chosen for determination of extractable radium using ammonium acetate (1N, $\mathrm{pH}$ 5.2) extracts and total radium activity as a function of depth. These samples were collected in May, June, and July of 1977 . The results of the extractable radium measurements are compared with total radium contents in Table 7. The total radium activity of the tailings at Site $B$ was somewhat higher than that at Site $A$. The total radium contents for Site A were lower than the overail average for the tailings pile, which is approximately $645 \mathrm{pCi} / \mathrm{g}$ (Dreesen and Wienke 1978). The mean extractable radium activity $(305 \pm 151 \mathrm{pCi} / \mathrm{g})$ at Site $\mathrm{B}$ was significantly greater $(\mathrm{P}<0.05)$ than that $(171 \pm 24$ $\mathrm{pCi} / \mathrm{g}$ ) at Site $\mathrm{A}$, but, for individual locations, the ratio of the extractable to total activity was 
Table 5. Rudium-226 activity' ( $\mathrm{pCi} / \mathrm{g}$ dry weight) of aboveground shoots of four species and associated substrates from site $B$.and an adjacent area during 1977

\begin{tabular}{|c|c|c|c|c|c|c|c|c|c|}
\hline \multirow[b]{2}{*}{ Location } & \multirow[b]{2}{*}{ Month } & \multicolumn{2}{|c|}{ Sitanion hystrix } & \multicolumn{2}{|c|}{ Sporobolus airoides } & \multicolumn{2}{|c|}{ Kochia scoparia } & \multicolumn{2}{|c|}{ Atriplex canesceno } \\
\hline & & Shoots & Substrate & Shoots & Substrate & Shoots & Substrate & Shoots & Substrate \\
\hline $\begin{array}{l}\text { Bare tailings } \\
\text { Bare tailings }\end{array}$ & $\begin{array}{l}\text { May } \\
\text { Jun }\end{array}$ & $\begin{aligned} 106 & \pm 27(2) \\
87 & \pm 16(2)\end{aligned}$ & $\begin{array}{l}986 \pm 430(3) \\
885 \pm 345(6)\end{array}$ & $24 \pm 1(1)$ & $643 \pm 368(3)$ & $103 \pm 69(2)$ & $598 \pm 321(3)$ & $11 \pm 1(1)$ & $736 \pm 92(3)$ \\
\hline Bare tailings & Aug & & & & & $73 \pm 4(1)$ & $426 \pm 136(2)$ & & \\
\hline Covered tailings' & Apr & $14 \pm 1(2)$ & & & & & & & \\
\hline Covered tailings & Jun & $0.03 \pm 0.3(1)$ & $104 \pm 11(1)$ & & & $13 \pm 0.9(1)$ & $56 \pm 11(2)$ & $8 \pm 0.5(2)$ & $71 \pm 9(1)$ \\
\hline Cuvered ia:lings & Oct & & & $34 \pm 2(1)$ & $62 \pm 5(1)$ & $53 \pm 2(1)$ & $44 \pm 4(1)$ & & \\
\hline Ådjacent area & May-Jun & $0.9 \pm 0.01(2)$ & $1.8 \pm 0.4(5)$ & $2.0 \pm 1.1(2)$ & $1.8 \pm 0.6(2)$ & $1.0 \pm 0.1(2)$ & $1.8 \pm 0.3(3)$ & $0.8 \pm 0.5(4)$ & $2.0 \pm 0.5(4)$ \\
\hline
\end{tabular}

${ }^{2}(n): n$ is number of samples; if $n=1$, measured value \pm analytical uncertainty; if $n>1$, mean activity \pm one standard deviation.

2Substrate activity given is that of soil overburden; radium content of tailings was $1125 \pm 153$ $\mathrm{pCi} / \mathrm{g}(\mathbf{n}=3)$. 
Table 6. Radium-226 activity' ( $\mathrm{pCi} / \mathrm{g}$ dry weight) of aboveground shonts of Kochlo scoparia and associated tailings from different locations at Site B

$$
\begin{array}{cc}
\text { Tailings } & \text { Shoots } \\
\hline 426 \pm 63 & 73 \pm 4 \\
457 \pm 55 & 70 \pm 3 \\
478 \pm 52 & 35 \pm 2 \\
930 \pm 78 & 82 \pm 3 \\
1000 \pm 78 & 58 \pm 2
\end{array}
$$

'Measured value \pm analytical uncertainty.

quite variable. This extrantion method dissolves carhonates (Bowen and Dymond 1956) and thus may be an upper estimate of extractable radium and may not be directly related to biologically available radium. For soils spiked with radium $(5-7 \mathrm{pCi} / \mathrm{g})$, the percentage of the radium extracted by ammonium acetate (1N) was 5 to $30 \%$ (Grzybowska 1974). Differences in surficial contamination could account for some variability in plant content. For example, in a

\begin{tabular}{|c|c|c|c|c|c|}
\hline \multirow[b]{2}{*}{ Site } & \multirow[b]{2}{*}{ Species" } & \multirow[b]{2}{*}{ Shoot Activity } & \multirow[b]{2}{*}{ Substrate } & \multicolumn{2}{|c|}{ Substrate Activity } \\
\hline & & & & Extractable & Total \\
\hline A & Sihy & $38 \pm 2(1)$ & tailings sand & $150 \pm 22$ & $254 \pm 53(4)$ \\
\hline A & Sihy & $31 \pm 3(1)$ & tailings pile & $150 \pm 20$ & $215 \pm 35\{3)$ \\
\hline A & Kosc & $271 \pm 8(1)$ & tailings pile & $188 \pm 23$ & $409 \pm 35(1)$ \\
\hline A & Saka & $368 \pm 13(1)$ & tailings pile & $194 \pm 17$ & $513 \pm 17(1)$ \\
\hline B & Sihy & $106 \pm 27(2)$ & tailings pile & $131 \pm 10$ & $986 \pm 430(3)$ \\
\hline B & Spai & $24 \pm 1(1)$ & tailings pile & $410 \pm 26$ & $643 \pm 368(3)$ \\
\hline $\mathrm{B}$ & Kosc & $103 \pm 69(2)$ & tailings pile & $230 \pm 28$ & $598 \pm 321(3)$ \\
\hline B & Atca & $11 \pm 2(1)$ & tailings pile & $450 \pm 25$ & $736 \pm 92(3)$ \\
\hline
\end{tabular}
study of particle creep and saltation, considerably more particulate material (19 times greater downwind and twice greater upwind) was collected at Site A compared to Site B (Marple,

Table 7. Radium-226 activity' (pCi/g dry weight) in aboveground shoots of several plant species and associated substrates (both extractable and total) from sites $A$ and $B$ and adjacent areas

\footnotetext{
${ }^{1}(n): n$ is number of samples; if $n=1$, measured value \pm analytical uncertainty; if $n>1$, mean activity \pm one standard deviation.

${ }^{2}$ Calculated value \pm analytical uncertainty from $1 \mathrm{~N} \mathrm{NH}$. OAc (pH 5.2) extracts.

${ }^{3}$ Sihy: Sitanion hystrix; Kosc: Kochia scoparia; Saka: Salsola kali; Atca: Atriplex canescens.
} 
Barr, and Dreesen 1978). Texture of the substrate could be important as it could influence cation exchange capacity and, therefore, exchangeable radium. For example, the Sitanion growing in tailings sand had lower radium content than that growing directly on the tailings pile at Site A, despite similar total and extractable radium activity in substrates from both locations.

The total radium activity in three depths $(0-5 \mathrm{~cm}, 5-15 \mathrm{~cm}$, and $15-25 \mathrm{~cm})$ is shown in Figure 3. Local soil from a drainage from a uranium mine (drainageway) was elevated in radium content compared to that from the rangeland. The high activity in the surface layers of these soils suggested the possibility of contamination by particulates transported by wind and water from tailings and ore. The total radium activity at Site $B$ was quite variable and usually increased with depth, possibly as a result of percolation and leaching. A trend toward increasing radium activity with depth was not evident at Site A either in these cores or thcse from other portions of the tailings pile (Marple, unpublished data, 1977).

A sampling of plant parts was conducted to determine relative radium contents of different parts. Samples were collected between June and October of 1977, depending on the fruiting time of the species. One sample was collected from Site $\mathrm{C}$, an inactive carbonate tailings pile near Sites $A$ and $B$. The aboveground tissues were air-cleaned in tive standard manner described earlier and roots were washed in a sonic water bath for one hour. The results are shown in Table 8 . The fruits usually had higher activity than the leaves. The roots often had elevated levels, but surficial contamination (as indicated by larger ratios of ash weight to oven-dry weight compared with the other parts) may have contributed to this. In the comparison of cleaning methods described earlier (see Table 2), a range of 72 to $86 \%$ of the measured activity of washed samples from tailings substrates was within the tissues. For the grass, stems had higher activities than leaves, but the reverse was usually found for the shrub. The grass stems being close to the ground could have appreciable contamination by splash-

Table 8. Radium-226 activity' (pCi/g dry weight) in different parts of several plant species from sites $A, B, C$, and adjacent areas

\begin{tabular}{|c|c|c|c|c|c|c|}
\hline \multirow[b]{2}{*}{ Site } & \multirow[b]{2}{*}{ Substrate } & \multirow[b]{2}{*}{ Species ${ }^{2}$} & \multicolumn{4}{|c|}{ Radium Activity of Plant Parts } \\
\hline & & & Fruits & Leaves & Stems & Roots \\
\hline $\mathbf{A}$ & rangeland & Sihy & $6.5 \pm 2.0$ & $0.9 \pm 0.2$ & $\mathrm{ND}^{\prime}$ & $1.1 \pm 0.8$ \\
\hline A & drainageway & Sihy & $2.8 \pm 1.3$ & $5.7 \pm 0.5$ & ND & $55 \pm 1.9$ \\
\hline A & tailings sand & Sihy & $30 \pm 2$ & $38 \pm 2$ & ND & $100 \pm 3$ \\
\hline $\mathbf{A}$ & tailings pile & Sihy & $153 \pm 7$ & $128 \pm 5$ & $279 \pm 15$ & $306 \pm 11$ \\
\hline B & tailings pile & Sihy & $103 \pm 4$ & $87 \pm 15$ & $167 \pm 7$ & $86 \pm 1$ \\
\hline $\mathbf{A}$ & tailings pile & Kosc & $245 \pm 72$ & $134 \pm 11$ & ND & $52 \pm 4$ \\
\hline $\mathbf{A}$ & tailings pile & Saka & $479 \pm 70$ & $328 \pm 28$ & ND & $253 \pm 20$ \\
\hline $\mathbf{A}$ & tailings sand & Saka & $83 \pm 8$ & $41 \pm 4$ & $\mathrm{ND}$ & $68 \pm 6$ \\
\hline A & tailings sand & Atca & $11 \pm 1$ & $4.9 \pm 0.5$ & $6.9 \pm 0.8$ & $25 \pm 8$ \\
\hline B & tailings pile & Atca & $125 \pm 5$ & $152 \pm 6$ & $93 \pm 4$ & ND \\
\hline $\mathrm{C}$ & tailings pile & Atca & $63 \pm 3$ & $46 \pm 2$ & $42 \pm 4$ & ND \\
\hline B & rangeland & Atca & $12 \pm 0.1$ & $0.6 \pm 0.7$ & $0 \pm 1.0$ & ND \\
\hline
\end{tabular}

'Measured value \pm analytical uncertainty.

'Sihy: Sitanion hystrix; Kosc: Kochia scoparia; Saka: Salsola kali; Atca: Atriplex canescens.

'ND: no data. 


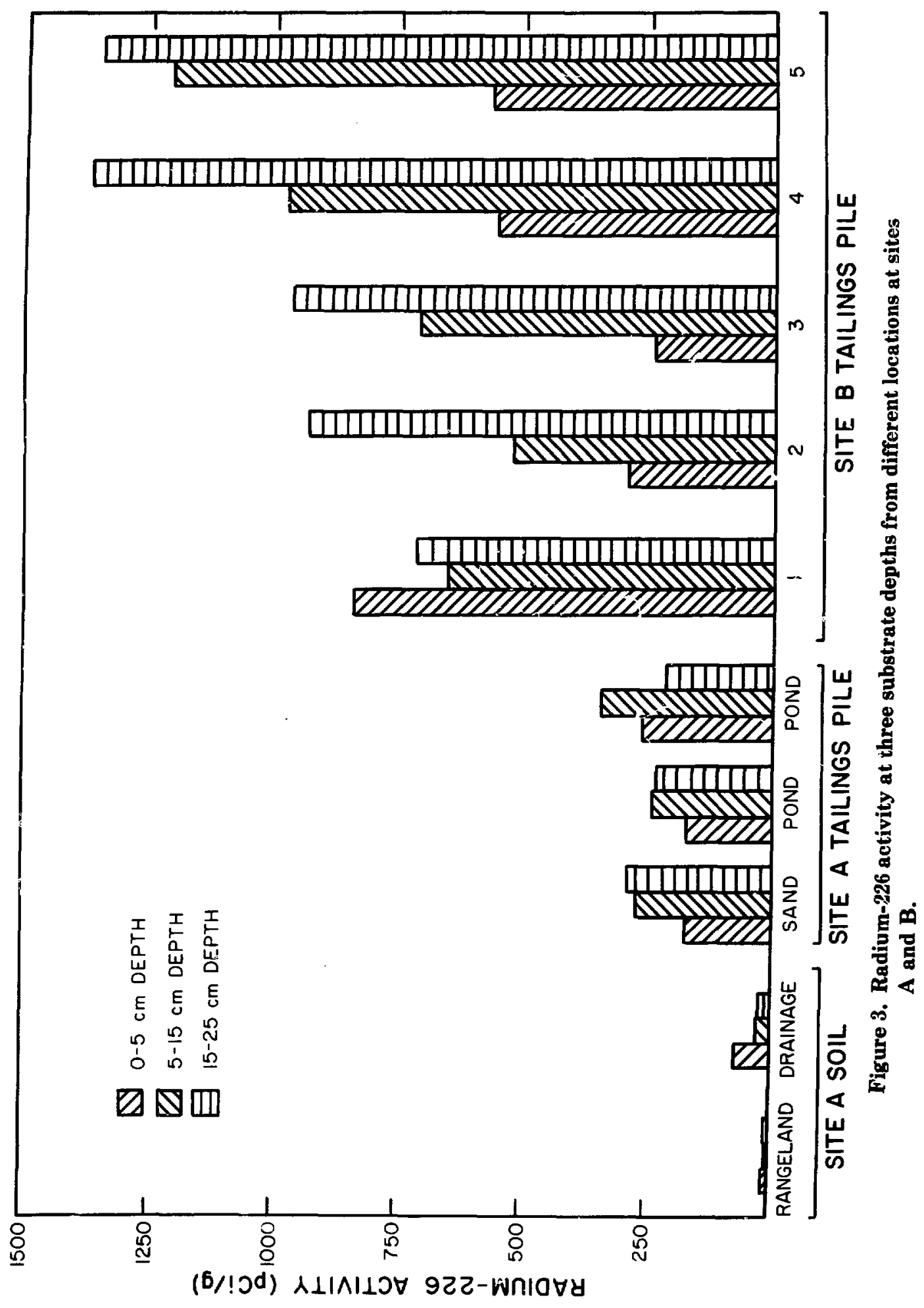


up, but that portion of the shrub stems collected was farther above the ground and less susceptible to this contamination. The results can be summarized as follows: (1) the fruits of Atriplex, Salsola, and Sitanion growing in tailings had higher radium activities than the leaves; (2) the stems showed variable relationships to the leaves; and (3) the 1oots had higher activities than the leaves for both the grass and the shrub, but not for the annual forbs, Kochia and Salsola. In a study downwind from a tailings pile, leaves usually had higher alpha activities than other aerial plant parts (Kotsch 1977). Similarly, for corn grown in spiked soils (up to $1350 \mathrm{pCi} / \mathrm{g}$ ), leaf activities were three times those of stems and 30 times those of fruits (Lepape and Trannoy 1934b). Roots often had activities from 10 to 100 times those of aboveground parts (Drobkov 1937). Baranov (1939) found little variation in root acivity of cultivated plants growing in nutrient solutions which varied by four orders of magnitude, but large differences in the radium content of the aboveground shoots; thus the root activity was 2 to 2000 times that of the aerial parts. For Pisum sativum grown in nutrient solutions of different radium contents, the roots had 2 to 26 times as much radium as the leaves and the radium activity of the stems was withir $30 \%$ of that of the leaves (Kirchmann and Berino 1965; Kirchmann, Roncucci, and Mousny 1965). Similarly, for beans grown in nutrient solution, the radium activity of the roots was four times greater than that of the shoots (D'Souza and Mistry 1970). However, for cultivated plants grown in spiked soils, the radium content of roots was less than, equal to, or greater than that of leaves depending on species (Kirchmann, Boulenger, and LaFontaine 1968), For a. grass grown in spiked soil, Grzybowska (1974) reported rot activities which were 1.8 times higher than those of the aboveground parts (1974). Thus, the relationship between radium activities of different plant parts can be variable depending on growth conditions and species. Most plants show increased activity in roots and comparable activities in stems as relative to leaves, and these trends were evident in the plant parts from Sites A and B.

Several investigations in the past have compared the uptake and translocation of alkaline earth elements, particularly calcium and strontium. Since strontium was a component of fallout and was readily translocated by plants compared to other radionuclides (Auerbach 1958), much research focused on it. Some results of studies with strontium and calcium could be applicable to radium results. Differences in plant concentrations of strontium, barium, and calcium were related to different rates of release fi $\mathrm{Jm}$ the soil and of uptake and translocation by the plant (Menzel 1954). Strontium distribution was similar to calcium but its movement within plants was slower (Martin, Newbould, and Russell 1958). For excised barley roots, strontium was seen to compete for binding sites with calcium and to a lesser degree with barium; Inagnesium did not compete with calcium (Epstein and Leggett 1954). The addition of calcium to nutrient solution or loam soil reduced strontium uptake by beans when the medium was low in calcium; with adequate calcium in the medium, the plant absorbed more strontium than calcium after a maximal calcium content in the plant was reached (Romney et al. 1959). At low strontium levels in the soil, it was preferentially absorbed over calcium (Bowen and Dymond 1956). Strontium, like calci Im, was readily absorbed by foliar application but little subsegent translocation occurred (Klechkovsky and Guliakin 1958; Biddulph 1960). For soils with increasing exchangeable calcium, there was a corresponding decrease in the ratio of strontium to calcium content in the plant (Squire 1966). For Brazil nuts and wheat, Smith (1967) found similar behavior in uptake of calcium and strontium. Thus, the studies showed that calcium and strontium behaved similarly with respect to plant availability, with a tendency for strontium uptake and translocation to be discriminated against. These results could be applicable to radium uptake as compared to calcium uptake.

The influence of soil properties such as calcium on radium uptake was investigated in selected samples from the field plants. Total calcium in substrates was measured by instrumental thermal neutron activation analysis; flame atomic absorption analysis was used to 
measure calcium in substrate extracts (made with $1 \mathrm{~N}$ ammonium acetate at pH 5.2) and in digested vegetation samples (Kelley 1979). Representative field samples from Sites A and B and from nearby soil are shown in Table 9. The cation exchange capacities of the three substrates are 5.3, 7.0, and 32 milliequivalents/100 $\mathrm{g}$ for the Site $\mathrm{A}$ tailings, Site $\mathrm{B}$ tailings, and local soil, respectively. Although all three substrates are rich in calcium, the tailings from Site $B$ are highest due to the limestone component of the ores. The calcium concentrations in the plants were lowest for the grass, intermediate for the forb, and highest for the shrub (means significantly different $(P<0.05)$ by approximate $t$-test), but were within the range reported for crop plants (Epstein 1972). The extractable radium activity in Site B tailings was higher than Site A tailings, but the fraction of that extractable was lower. At Site B, a higher calcium fraction and lower extractable radium content of the substrate was noted; a similar decrease in radium leachability with increased calcium content was reported for soils (Rusanova 1962). A decrease in radium uptake from soils spiked with calcium was found for several cultivated plants (Kirchmann, Boulenger, and Lafontaine 1968). The lower radium content of plants relative to the activity of the subsal cultivated plants (Kirchmann, Boulenger, and Lafontaine 1968). The lower radium content of plants relative to the activity of the substrate at Site $B$ could be a reflection of the lower radium leachability and higher calcium content. The radium:calcium ratio in the biomass was lower than that for the substrates only for Atriplex. This suggests that radium may have been discriminated against in absorption and/or translocation relative to calcium in this species. Similar discrimination was observed for cultivated species grown on spiked soils (Kirchmann, Boulenger, and Lafontaine 1968).

Selected samples from Site A collected in October 1977 were also analyzed for total calcium. The results of analysis of air-cleaned plant samples and the associated substrates, both dry fines and bulk, are presented in Table 10. The background samples have higher levels of calcium than the samples from tailings sand despite lower calcium concentration in soil. The shrub has the highest calcium concentrations and the grass, the lowest. The ratio in the biomass of Atriplex was lower than that in the substrates, suggesting discrimination against radium relative to calcium. For strontium, the ratio of its content to calcium content in the plant was found to be a power function of that reported for the soil (Bowen and Dymond 1956; Francis 1978). Therefore, a power function like this was fitted to radium:calcium ratios for plants and substrates; that is, the ratio for the plant $(y)$ is a function of the same ratio $(x)$ for the substrate in the form $y=a x^{b}$ in Figure 4. The fit for these curves was quite good for both dry fines and bulk substrate concentrations ( 0.97 and 0.83 , respectively). The radium:calcium ratios for Atriplex and both associated substrates were small compared to those for Kochia and Sitanion. All these ratios were small compared to those reported for food (Penna-Franca et al. 1965b) and for plants grown on spiked soil (Rusanova 1964; Grzybowska 1974), which were greater than $10 \mathrm{pCi} \mathrm{Ra-226/g} \mathrm{Ca.}$

In summary, the results of measurements of radium contents of plants and substrates from Sites $A$ and $B$ showed the uptake, but not the concentration, of radium into plant tissues. The concentration ratios are from 0.1 to 1.0 for most samples from both tailings piles and local soils. Similar concentration ratios have been reported for cultivated plants (Menzel 1965; Kirchmann, Boulenger and Lafontaine 1968). For Atriplex, there is evidence of discrimination against radium relative to calcium. A comparison of the three species which grew at both Sites $A$ and $B$ reveals that the radium content of Sitanion and Atriplex from both sites was similar, but that the activity of Kochia from Site $A$ was significantly greater $(P<0.05)$ than the; from Site B. In contrast, the tailings from the locations where these species were growing had significantly greater $(P<0.05)$ radium activity at Site $B$ compared to Site $A$. The greater calcium content in the tailings from Site B could explain this lower uptake of radium by the plants. At Site B, the radium activity of three species was lower when growing in covered tailings. Such reductions have been reported for plants grown on soils spiked with radium at 20 to 
Table 9. Radium-226 activity (pCi/g dry weight), calcium concentration (percentage), and radium:calcium ratio ( $\mathrm{pCi} \mathrm{Ra-226} / 100 \mathrm{~g} \mathrm{Ca}$ ) in aboveground shoots and associated substrates (both total and extractable) from sites $A$ and $B$ and adjacent rangeland
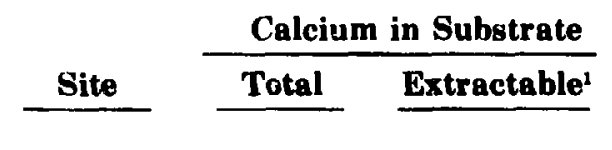

A

B

$$
\mathrm{ND}^{7} \quad 8.6 \pm 1.1(12)
$$

Rangeland$$
2.0 \pm 0.6 \quad 1.8 \pm 0.6(4)
$$

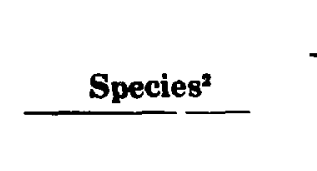

\begin{tabular}{|c|c|}
\hline \multicolumn{2}{|c|}{ Shoot } \\
\hline 'Ra-226 & $\mathrm{Ca}^{4}$ \\
\hline $85 \pm 31(7)$ & U.4 \\
\hline $150 \pm 63(5)$ & 0.5 \\
\hline $12 \pm 6(6)$ & 1.0 \\
\hline $97 \pm 13(2)$ & 0.4 \\
\hline $65 \pm 34(6)$ & 0.7 \\
\hline $11 \pm 1(1)$ & 1.1 \\
\hline $0.9 \pm 0.1(2)$ & 0.2 \\
\hline $1.0 \pm 0.1(2)$ & 0.6 \\
\hline $1.1 \pm 0.1(3)$ & 1.4 \\
\hline
\end{tabular}

\begin{tabular}{r} 
Ratio \\
\hline 213 \\
300 \\
12 \\
\\
243 \\
93 \\
10 \\
\\
4.5 \\
1.7 \\
0.8
\end{tabular}

$\frac{\text { Ra-226 in Substrate }}{\text { Total }^{\mathbf{2}} \text { Extractable }}$

Substrate Ratio

$\begin{array}{ll}274 \pm 74(16) & 150 \pm 20 \\ 346 \pm 128(5) & 194 \pm 17\end{array}$

$160 \pm 3(5) \quad 150 \pm 22$

$804 \pm 350(9) \quad 131 \pm 10$

$597 \pm 260(10) \quad 230 \pm 28$

$736 \pm 92(3) \quad 450 \pm 25$

ND

ND

ND

86
108
50

93
69
86

'Data from Kelley 1979; means significantly different $(\mathrm{P}<0 .(01)$ by approximate $t$-test.

'Sihy: Sitanion hystrix, Kosc: Kochia scoparia; Atca: Atriplex canescens.

${ }^{8}(n): n$ is number of samples; if $n=1$, measured value \pm analytical uncertainty; if $n>1$, mean activity \pm one standard deviation.

'Data from Kelley 1977.

'Calculated from radium-226 actvity of $1 \mathrm{~N} \mathrm{NH} 4 \mathrm{OAc}(\mathrm{pH} \mathrm{5.2)}$ extract; calculated value \pm analytical uncertainty.

'Ratio of total radium to extractable calcium.

'ND: no data. 
Table 10. Radium-226 activity ${ }^{1}$ ( $\mathrm{pCi} / \mathrm{g}$ dry weight), calcium concentration ${ }^{2}$ (percentage), and radium:calcium ratio ( $\mathrm{pCi} \mathrm{Ra}-226 / 100 \mathrm{~g} \mathrm{Ca}$ ) in aboveground shoots and associated substrates (bulk and fines ${ }^{2}$ ) from site $A$ and an adjacent area

Shoots

Substrate

\begin{tabular}{|c|c|c|c|c|c|c|c|c|}
\hline \multicolumn{4}{|c|}{ Shoots } & \multicolumn{5}{|c|}{ suostrate } \\
\hline Species & Radium-226 & Calcium & Ratio & Description & Fraction & Radium-226 & Calcium & Ratio \\
\hline $\begin{array}{l}\text { Sitanion } \\
\text { hystrix }\end{array}$ & $110 \pm 4$ & $0.4 \pm 0.1$ & 275 & Tailings and soil & $\begin{array}{l}\text { bulk } \\
\text { fines }\end{array}$ & $\begin{array}{l}443 \pm 35 \\
368 \pm 13\end{array}$ & $\begin{array}{l}7.1 \pm 0.7 \\
3.8 \pm 0.9\end{array}$ & $\begin{array}{l}62 \\
97\end{array}$ \\
\hline $\begin{array}{l}\text { Kochia } \\
\text { scoparia }\end{array}$ & $112 \pm 6$ & $0.5 \pm 0.1$ & 224 & Tailings pond & $\begin{array}{l}\text { bulk } \\
\text { fines }\end{array}$ & $\begin{array}{l}409 \pm 35 \\
641 \pm 11\end{array}$ & $\begin{array}{l}3.4 \pm 0.1 \\
5.2 \pm 0.1\end{array}$ & $\begin{array}{l}120 \\
123\end{array}$ \\
\hline $\begin{array}{l}\text { Atriplex } \\
\text { canescens }\end{array}$ & $4.9 \pm 0.5$ & $1.1 \pm 0.1$ & 4.45 & Tailings sand & $\begin{array}{l}\text { bulk } \\
\text { fines }\end{array}$ & $\begin{array}{l}112 \pm 10 \\
240 \pm 9\end{array}$ & $\begin{array}{r}4.6 \pm 0.5 \\
14 \pm 1.8\end{array}$ & $\begin{array}{l}24 \\
17\end{array}$ \\
\hline $\begin{array}{l}\text { Atriplex } \\
\text { canescens }\end{array}$ & $1.1 \pm 0.3$ & $1.4 \pm 0.1$ & 0.8 & Local rangeland & $\begin{array}{l}\text { bulk } \\
\text { fines }\end{array}$ & $\begin{aligned} 2.6 & \pm 0.3 \\
28 & \pm 1\end{aligned}$ & $\begin{array}{l}2.0 \pm 0.6 \\
2.1 \pm 0.9\end{array}$ & $\begin{array}{l}1.3 \\
13\end{array}$ \\
\hline
\end{tabular}

'All values given are results of one measuremer: \pm analytical uncertainty.

'Fines:fraction $<53 \mu \mathrm{m}$ produced by sonically sieving dry samples. 


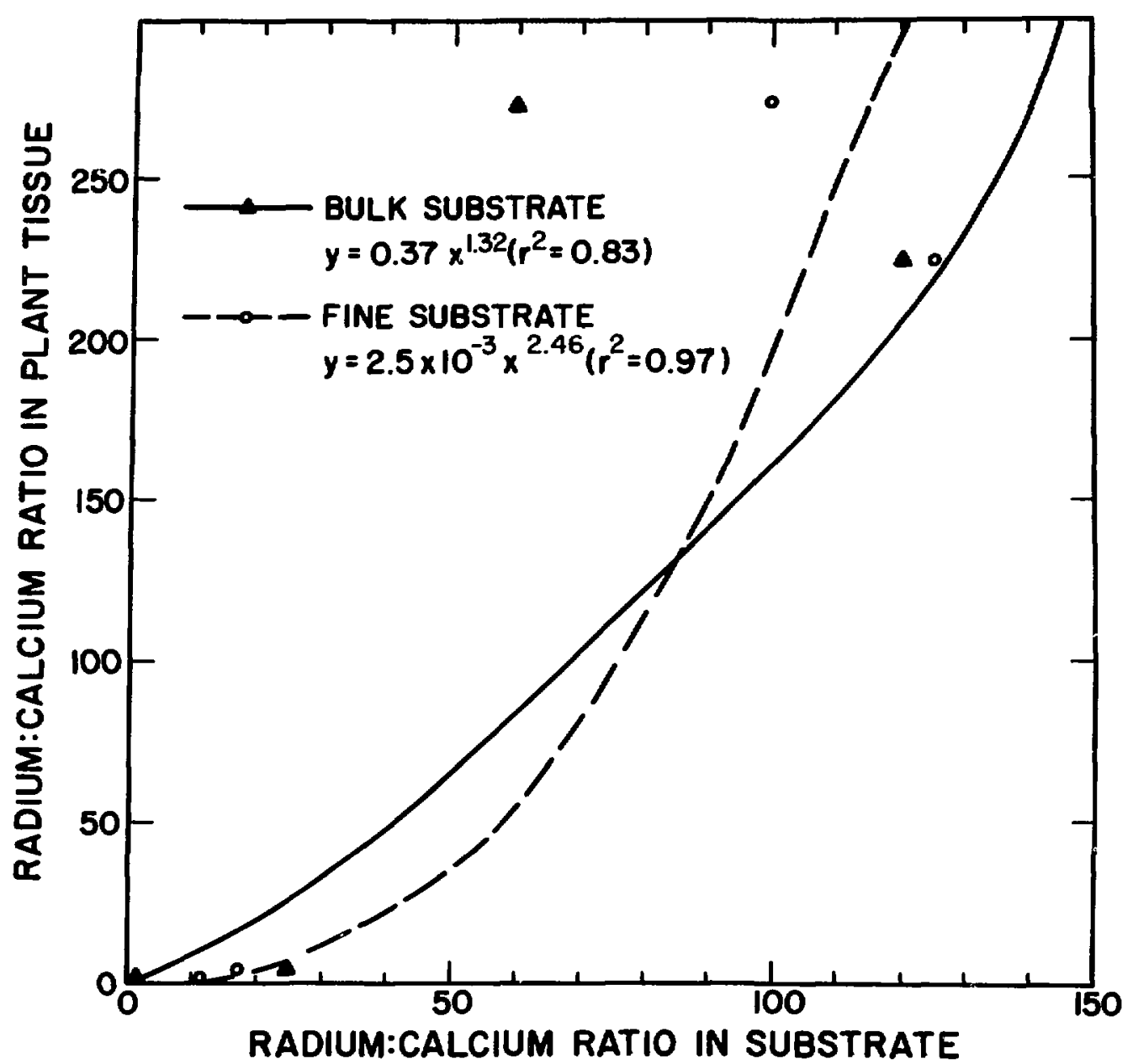

Figure 4. Radium:calcium ratio (pCi $\mathrm{Ra}-226 / 100 \mathrm{~g} \mathrm{Ca}$ ) in plant shoots as a power function of that ratio in the substrate.

$30 \mathrm{~cm}$ depth (Grzybowska 1974) and for plants grown on a sand and gravel cover (20-50 cm thick) over a substrate of high radium activity, $500 \mathrm{pCi} / \mathrm{g}$ (Maslov, Gruzdev, and Maslova 1969). The radium activity of the plants from Sites $A$ and $B$ is greater than that reported for grasses $(5.5 \mathrm{pCi} / \mathrm{g})$ grown with fertilization and lime application on acid tailings containing $196 \mathrm{pCi} / \mathrm{g}$ (Moffett and Tellier 1977). However, the plant and substrate activities from both tailings and soils at Sites $A$ and $B$ are similar to those reported from the vicinity of uranium mines and mills in Wyoming (Winsor and Stahlecker 1974; Winsor and Whicker 1975). The mean radium activities for local soils at Sites $A$ and $B$ and for plants growing in these were 2.1 $\pm 0.9 \mathrm{pCi} / \mathrm{g}(\mathrm{n}=11)$ and $1.0 \pm 0.6 \mathrm{pCi} / \mathrm{g}(\mathrm{n}=15)$. Similar results have been reported for wheat and sugar beets grown in soil treated with phosphate fertilizers containing $0.9 \mathrm{pCi} / \mathrm{g}$ (Kirchmann, Darcheville, and Koch 1980). The measurements of radium activity in the local soils fit a lognormal distribution $\left(r^{2}=0.97\right)$ as was previously described for such measurements near Hanford (Miller, Fix, and Bramson 1977 and 1980). The geometric mean for the soil activity at Sites A and B was $1.6 \mathrm{pCi} / \mathrm{g}$. The coefficient of variation for local soils (40\%) was within the range reported for other radionuclides (Eberhardt 1976). The mean radium content 
of the local soils from Sites A and B was slightly lower than that previously reported (3.3 $\mathrm{pCi} / \mathrm{g}$ ) for background soils in the Grants Mineral Belt (Eadie et al. 1976). In conclusion, the tailings at Sites $\mathrm{A}$ and $\mathrm{B}$ had radium activities ranging from 140 to $1400 \mathrm{pCi} / \mathrm{g}$. All plant species growing in tailings had radium contents significantly greater than those growing in local soils. The order of decreasing radium activity in plant samples was as follows: Salsola $>$ Kochia $>$ Sitanion $>$ Sporobolus $>$ Atriplex, with a factor of 20 variation between Salsola and Atriplex ( $\sim 12 \mathrm{pCi} / \mathrm{g}$ dry weight). Within one species, variations by a factor of two to three with time and with location were observed.

\section{Survey of Inactive Uranium Mill Sites in the Four Corners Region}

Selected plant species were collected and analyzed for radium -226 activity from several inactive uranium mill sites in order to evaluate the importance of plant uptake as a mechanism of contaminant transport for radium and to compare activities found at Sites A and B with those of other mill sites. The effect of a shallow soil overburden on plant uptake of radium was also addressed. The locations included nine acid tailings piles (Sites D, E, F, G, H, K, P, R, and $S$ ), two carbonate tailings piles (Sites $A$ and $C$ ), three piles with acid and carbonate tailings mixed together (Sites I, L, and O), three upgrade piles (Sites J, N, and Q), and one evaporation pond (Site M). Samples from Site A were collected from seeded plots covered with a sparse rock cobble (Kelley 1979). Species which had been analyzed at Sites A and B and species which were common to several sites were chosen for analysis: (1) the perennial grass Agropyron desertorum (crested wheatgrass); (2) the perennial grass Agropyron elongatum (tall wheatgrass); (3) Sitanion hystrix; (4) Sporobolus airoides; (5) Kochia scoparia; (6) the annual or biennial forb Melilotus officinalis (yellow sweetclover); (7) Salsola kali; (8) the perennial shrub Artemisia tridentata (big sagebrush); and (9) Atriplex canescens. Both Agropyron species are naturalized from Eurasia and have become established outside cultivation; they were seeded in revegetation projects at several sites and were successful (Beverly 1968). Sitanion was an invader on many sites. Sporobolus and Molilotus (also a naturalized species escaping from cultivation) were also seeded in revegetation projects, but were not dominant (Donovan, Felder, and Rogers 1976). The annual forbs Kochia and Salsola were frequent invaders. The shrubs Atriplex and Artemisia were invaders from the surrounding areas where they are important species in the shrub communities of the Colorado Plateau. At certain sites, some of these species and tailings were sampled for trace element analyses (Kelley 1979).

Substrate samples, including both tailings and soil overburden where present, were collected at the base of sampled plants. At most sites, three tailings samples and a compasite overburden sample were analyzed for total radium. A composite tailings sample was used for ammonium acetate ( $\mathrm{pH} \mathrm{5.2)} \mathrm{extraction.} \mathrm{The} \mathrm{mean} \mathrm{activities} \mathrm{in} \mathrm{vegetation,} \mathrm{tailings} \mathrm{extracts,}$ and bulk soil and tailings for covered and uncovered tailings piles are shown in Table 11. The radium content of plants ranged from background levels to more than nine times these levels for covered piles; on uncovered piles, all activities were elevated, but varied by more than one order of magnitude. The mean activities for plants were $4.3 \pm 5.9 \mathrm{pCi} / \mathrm{g}(\mathrm{n}=39)$ and $38 \pm 48$ $\mathrm{pCi} / \mathrm{g}(\mathrm{n}=21)$ for covered and uncovered piles, respectively. These are both significantly greater than the mean activity $(1.0 \pm 0.6 \mathrm{pCi} / \mathrm{g}, \mathrm{n}=15)$ of plants growing on local soil in the Grants Mineral Belt ( $P<0.01$ using the approximate t-test). The difference between these two means also has the same statistical significance. Individually, plants from seven of the nine uncovered piles had mean activities significantly greater than that of control plants $(P<0.01$ or $P<0.001$ using the approximate $t$-test); the two sites ( $L$ and $R$ ) with less significant differences had plants with radium activities of $8 \mathrm{pCi} / \mathrm{g}$ or greater, but showed an order of 
Table 11. Mean radium-226 activity (pCi/g dry weight) in aboveground shoots from several plant species, tailings (both total and extractable), and soil overburdens (where present) from inactive uranium mill sites in the Four Corners Region

\section{Covered Tailings}

\begin{tabular}{|c|c|c|c|c|}
\hline \multirow[b]{2}{*}{ Site } & \multirow[b]{2}{*}{ Shoots $^{1}$} & \multicolumn{2}{|c|}{ Tailings } & \multirow[b]{2}{*}{ Overburden ${ }^{1}$} \\
\hline & & Total ${ }^{1}$ & Extractable ${ }^{2}$ & \\
\hline D & $9.2 \pm 11(6)$ & $395 \pm 160(3)$ & $75 \pm 8$ & $11 \pm 1(1)$ \\
\hline $\mathbf{E}$ & $8.5 \pm 14(4)$ & $744 \pm 59(3)$ & $247 \pm 10$ & $10 \pm 1(1)$ \\
\hline $\mathbf{H}$ & $4.0 \pm 3.9(4)$ & $320 \pm 4(2)$ & $205 \pm 10$ & $20 \pm 1(1)$ \\
\hline I & $7.0 \pm 2.9(5)$ & $287 \pm 175(3)$ & $150 \pm 10$ & $13 \pm 1(1)$ \\
\hline $\mathbf{J}$ & $3.2 \pm 4.5(4)$ & $145 \pm 65(3)$ & $83 \pm 10$ & $13 \pm 1(1)$ \\
\hline $\mathbf{K}$ & $1.4 \pm 0.5(4)$ & $757 \pm 35(2)$ & $425 \pm 15$ & $7 \pm 8(2)$ \\
\hline $\mathbf{M}$ & $0.8 \pm 0.8(6)$ & ND & ND & $3 \pm 0.4(1)$ \\
\hline $\mathbf{N}$ & $4.2 \pm 0.3(2)$ & $140^{4}$ & ND & $17 \pm 13(2)$ \\
\hline 0 & $4.9 \pm 6.0(4)$ & $548 \pm 52(1)$ & ND & $23 \pm 37(3)$ \\
\hline
\end{tabular}

Bare Tailings

\begin{tabular}{|c|c|c|c|}
\hline \multirow[b]{2}{*}{ Site } & \multirow[b]{2}{*}{ Shoots ${ }^{1}$} & \multicolumn{2}{|c|}{ Tailings } \\
\hline & & Total $^{\mathbf{1}}$ & Extractable ${ }^{2}$ \\
\hline A & $50 \pm 29(3)$ & $993 \pm 54(3)$ & ND \\
\hline C & $47 \pm 3(3)$ & $171 \pm 5(3)$ & ND \\
\hline $\mathbf{F}$ & $4.4 \pm 2.0(4)$ & $354 \pm 448(3)$ & $341 \pm 9$ \\
\hline G & $9.2 \pm 1.2(2)$ & $426 \pm 21(3)$ & $275 \pm 20$ \\
\hline $\mathbf{L}$ & $88 \pm 83(4)$ & $681 \pm 41(3)$ & $295 \pm 15$ \\
\hline $\mathbf{P}$ & $30 \pm 1(1)$ & $392 \pm 43(1)$ & ND \\
\hline $\mathbf{Q}$ & $20 \pm 1(1)$ & $44 \pm 4(1)$ & ND \\
\hline $\mathrm{R}$ & $47 \pm 55(2)$ & $261 \pm 26(1)$ & ND \\
\hline $\mathbf{S}$ & $16 \pm 2(1)$ & $392 \pm 98(2)$ & ND \\
\hline
\end{tabular}

${ }^{1}(n): n$ is number of samples; if $n=1$, measured value \pm analytical uncertainty; if $n>1$, mean activity \pm one standard deviation.

'Calculated from activity of $1 \mathrm{~N} \mathrm{NH}, \mathrm{OAc}$ ( $\mathrm{pH} 5.2$ ) extract of composite tailings sample; calculated value \pm analytical uncertainty.

'ND: no data.

‘U.S. Atomic Energy Commission 1974. 
Table 12. Radium-226 activity ${ }^{1}$ (pCi/g dry weight) in aboveground shoots of nine plant species from inactive uranium mill sites in the Four Corners Region

Grasses

Site Agropyron Agropyron Sitanion $\begin{aligned} & \text { Sporobolus } \\ & \text { desertorum elongatum }\end{aligned}$

Covered

D $\quad 3.1 \pm 0.4$

$0.8 \pm 0.2$

$27 \pm 1$

$0.3 \pm 0.1$

$\mathbf{E}$

I $\quad 7.2 \pm 0.8$

ล

J

$\mathbf{K}$

$\mathrm{M}$

$9.7 \pm 0.5$

$11 \pm 0.6$

$0.4 \pm 0.1$

$3.3 \pm 0.4$

$+0.4$

\section{$30 \pm 1$}

$4.3 \pm 0.4$

$10 \pm 0.4$

$2.1 \pm 0.2$

$0.5 \pm 0.4$

N

O $\quad 0.2 \pm 0.1$

$13 \pm 1$

Bare

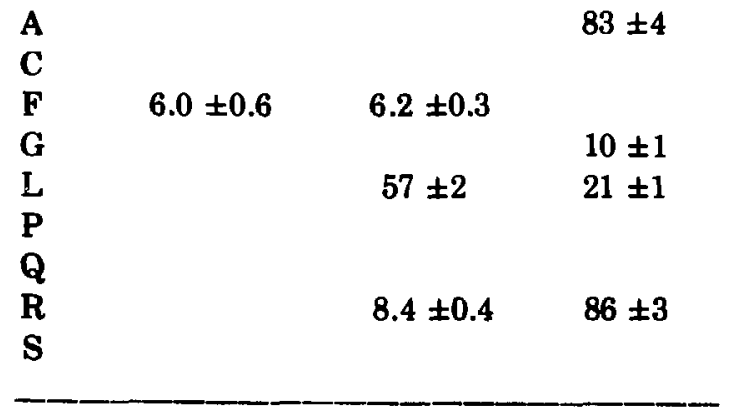

$45 \pm 2$

\begin{tabular}{ccc}
\hline & Forbs \\
\hline Kochia & $\begin{array}{c}\text { Melilotus } \\
\text { scoparia }\end{array}$ & $\begin{array}{c}\text { Saloola } \\
\text { officinalis }\end{array}$ \\
\hline
\end{tabular}

\begin{tabular}{|c|c|}
\hline \multicolumn{2}{|c|}{ Shrubs } \\
\hline $\begin{array}{l}\text { Artemisia } \\
\text { tridentate }\end{array}$ & $\begin{array}{l}\text { Atriplex } \\
\text { canescent }\end{array}$ \\
\hline
\end{tabular}

'Measured value \pm analytical uncertainty.

$\begin{array}{lrrrr}19 \pm 1 & 1.4 \pm 0.4 & & 1.5 \pm 0.4 & \\ 1.4 \pm 0.3 & & 2.9 \pm 0.4 & & 1.4 \pm 0.3 \\ 3.9 \pm 0.4 & & 3.4 \pm 0.3 & & \\ 1.0 \pm 0.1 & & 8.4 \pm 0.3 & & 0.7 \pm 0.1 \\ & & 1.1 \pm 0.2 & & 1.0 \pm 0.4 \\ 0.2 \pm 0.1 & 0 \pm 0.3 & 2.1 \pm 0.1 & & 4.0 \pm 0.4 \\ & & 4.4 \pm 0.4 & \\ 0.6 \pm 0.2 & & 5.9 \pm 0.3 & \\ & & & \\ 31 \pm 2 & & 37 \pm 1 & \\ & & 51 \pm 2 & \\ 2.1 \pm 0.3 & & 3.2 \pm 0.4 & \\ 8.1 \pm 0.7 & & & \\ & 64 \pm 7 & 210 \pm 8 & \\ & & 30 \pm 1 & \\ & & 20 \pm 1 & \\ & & 16 \pm 2 & \end{array}$


magnitude variation between species. The soil overburden at all sites showed radium contamination, with the evaporation ponds (Site $M$ ) being the lowest and Site 0 , which has been covered the longest, being the highest; five of the nine covered sites had activities in the range of 10 to $17 \mathrm{pCi} / \mathrm{g}$. The mean radium activity for the soil overburdens was $13 \pm 6 \mathrm{pCi} / \mathrm{g}(\mathrm{n}=9)$ and this is significantly greater than the mean activity for local soil in the Grants Mineral Belt $(2.1 \pm 0.9 \mathrm{pCi} / \mathrm{g}$ based on 11 measurements) using the approximate $t$-test $(P<0.001)$. The radium activities of the tailings varied by more than an order of magnitude, with large variations within a site being common. The upgrader piles (Sites $\mathrm{J}, \mathrm{N}$, and Q) were the lowest; these results are comparable to those reported by the U.S. Atu.nic Energy Commission (1974). Extractable radium varied less, with four out of nine values being between 200 and $300 \mathrm{pCi} / \mathrm{g}$. The ratio of extractable to total radium ranged from 0.19 to 0.96 , but five out of the nine values fell in the range of 0.52 to 0.65 . Overall, the mean total radium activity of these tailings was $415 \mathrm{pCi} / \mathrm{g}$. Thus, the plants showed concentration ratios of approximately 0.01 for covered piles and 0.1 for uncovered piles.

A comparison between species and sites is shown in Table 12. All species at certain sites, like $\mathrm{F}$ and $\mathrm{G}$, had relatively low radium activities for uncovered piles; this could be related to the irrigation used for revegetetion and possible leaching of soluble radium from the root zone. Such leaching of metals and radium from the surface layer of revegetated tailings was previously reported (Moffett and Tellier 1977). Seven of the 15 sites with more than one species had variations of a factor of 10 or greater between species; all but one of the other sites had variations by a factor of 1.1 to 2.8 between species. The variations in radium content between sites within a species were even larger, as might be expected with differences in tailings and soil overburdens. Large variations (factors of 60 to 95 ) occurred on both covered and uncovered piles. The smallest variations (factors of 1.4 to 7.6) occurred on covered piles, possibly due to the reduction of surficial contamination.

Comparisons of radium-226 content among plant species from covered and uncovered sites are shown in Figure 5. For all species, samples from uncovered sites had higher activities than those from covered sites. The low radium content of the shrubs Artemisia and Atriplex on covered tailings was evident. A grass, Agropyron elongatum had significantly higher radium content compared to three of the other species on coverer tailings piles (significance with $\mathrm{P}<0.1$ using approximate t-test). Another grass, Sporobolus, had the next highest activities and the forb Salsola had a mean acivity significantly greater than control plants $(\mathrm{P}<0.01$ using a t-test). On uncovered piles, several species had activities around $50 \mathrm{pCi} / \mathrm{g}$; the forb Kochia scoparia had the lowest value at $14 \mathrm{pCi} / \mathrm{g}$. For five of the eight species which occurred on uncovered piles, the mean activity was significantly greater $(\mathrm{P}<0.1$ using the approximate t-test) than both the mean for the covered piles and the mean for control plants. Two of the species for which this was not the case (Agropyron elongatum and Kochia) had high radium contents, but had two orders of magnitude variation between sites; the third species, Agropyron desertorum, had a radium content significantly $(\mathrm{P}<0.001)$ greater than control plants, but not greater than uncovered piles. These activities are lower than the range of activities described earlier for Sites $A$ and $B$, but the irrigation used at many of the other sites for revegetation could have removed the readily available radium. In summary, the radium activity of plant samples from all inactive sites were somewhat elevated. The presence of a soil overburden decreased radium uptake, but the higher radium activities of the overburden compared to normal soil indicated contaminant movement. This was reflected in activities higher than background for plants growing on covered tailings piles.

\section{Greenhouse Experiment}

The studies of the radium uptake by plants growing on uranium mill tailings in the field showed a significant content of radium in plant parts and some possible species differences. 


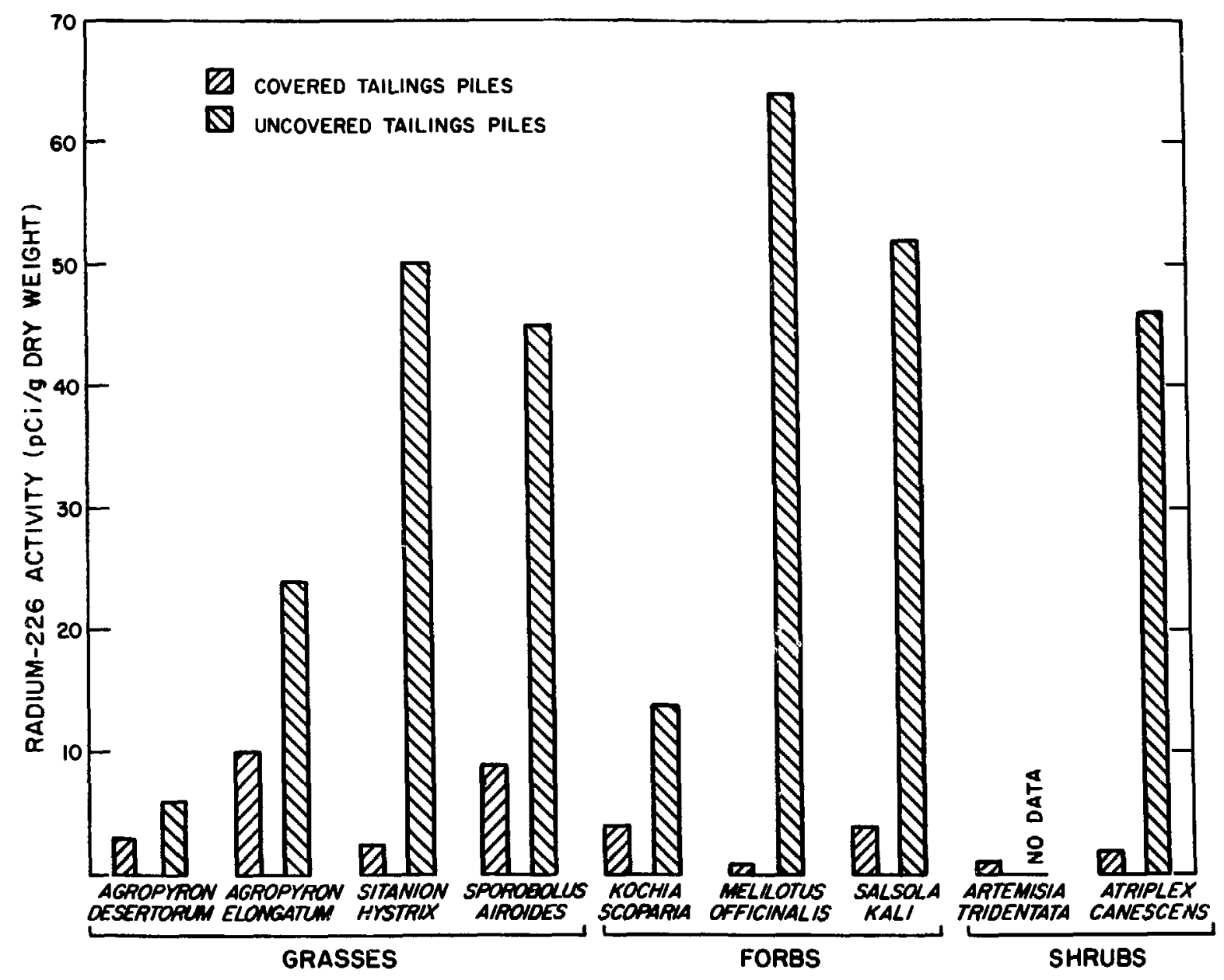

Figure 5. Summary of mean radium-226 activity in different plant species wherever they occurred on covered and uncovered tailings piles at several inactive uranium mill sites in the Four Corners Region. 
However, wide variations in activities and surficial contamination from wind-blown tailings particles made it difficult to show significant trends. A study of radium uptake under greenhouse conditions in the absence of surficial contamination was conducted from March to October 1978. Two species, the grass Sporobolus airoides and the shrub Atriplex canescens, were chosen for this study. These species are common throughout the Four Corners Region, were found growing on several inactive sites, and are often used in revegetation projects (Kelley 1979).

The experimental design consisted of the two plant species, three soils, and two substrate treatments, for which there were four replicates of the control treatment and six replicates of the tailings treatment. The number of replicates in the tailings treatment was greater to assure enough biomass for analysis despite potentially poor growth. The tailings treatment was $6 \mathrm{~cm}(800 \mathrm{~g})$ of moist tailings (a sands and slimes mixture with $15 \%$ moisture) from the tailings pile at Site $A$ in the bottom of a clay pot ( $15 \mathrm{~cm}$ diameter and $15 \mathrm{~cm}$ height) covered with $5 \mathrm{~cm}$ of one of three soils, as shown in Figure 6. The three soils were as follows: (1) dune sand, from the West Mesa of Albuquerque, NM, with a field capacity of $7 \pm 2 \%$; (2) clay loam, from an area adjacent to Site $A$, with a field capacity of $28 \pm 3 \%$, and (3) clay from an area adjacent to Site $B$, with a field capacity of $40 \pm 6 \%$. The field capacity of the tailings was $21 \pm 3 \%$. There were three control treatments, each containing only soil of one of the three types to a depth of $11 \mathrm{~cm}$ (see Figure 6). Approximately $0.2 \mathrm{~g}$ of grass seed and $2.0 \mathrm{~g}$ of shrub seed were used. All pots were covered with a layer about $1 \mathrm{~cm}$ deep $(21 \mathrm{~g})$ of perlite to reduce desiccation. The pots were watered by weight to the field capacity of the soil only two or three times per week; during the first ten weeks of the experiment, distilled water was used, but dilute (1:20) Hoagland's nutrient solution was used once per week in the remainder of the experiment. The pots were rotated systematically after every other watering to avoid edge effects. No artificial light was used; the temperatures in the greenhouse during May, June, and July were 20 to $23^{\circ} \mathrm{C}$ in the morning and 24 to $30^{\circ} \mathrm{C}$ in the afternoon. A fungicide (tetramethylthiuram disulfide) was applied after evidence of fungal growth was noticed and some pots required reseeding during the fourth week. In some pots with numerous shrub plants, the number of seedlings was reduced to 12 by thinning. All treatments showed some replicates with little or no growth; so the number of replicates for biomass measurements varied. For nine of the twelve treatments, all replicates were composited to make one sample for radium-226 analysis; for the other three treatments, the biomass was sufficient to allow two replicates.

Table 13. Radium-226 activity ${ }^{1}$ (pCi/g dry weight) of substrates from greenhouse experiment

\begin{tabular}{lc}
\multicolumn{1}{c}{ Substrate } & \multicolumn{1}{c}{ Activity } \\
Tailings & $613 \pm 31(3)$ \\
Dune sand & $0.15 \pm 0.21(2)$ \\
Clay loam & $2.7 \pm 0.5(2)$ \\
Clay & $0.36 \pm 0.18(2)$
\end{tabular}

'Mean activity \pm one standard deviation; $(n): n$ is number of samples.

${ }^{2}$ Mean activities significantly different between all three soils and the tailings $(P<0.001)$; mean activity of the dune sand and clay significantly different from clay loam $(P<0.05)$. 


\section{TAILINGS TREATMENT}

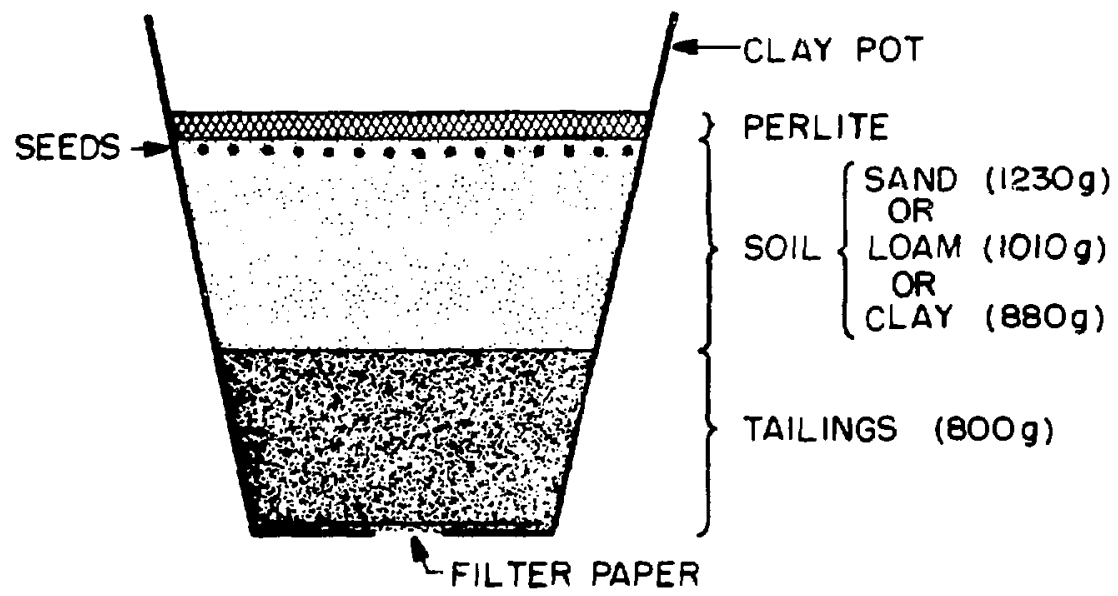

CONTROL TREATMENT

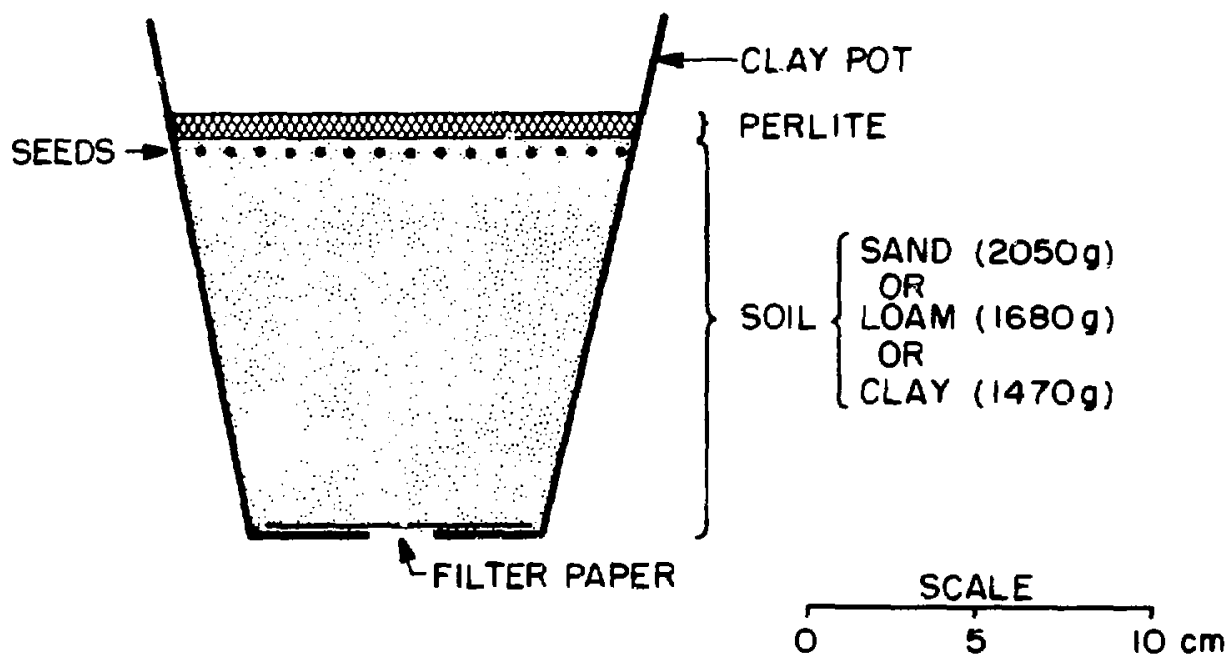

Figure 6. Diagram of tailings and control treatments from greenhouse experiment. 
Composite samples of the tailings and soils were analyzed for total radium activity. The results are shown in Table 13. The tailings had a higher radium content than those associated with the field samples at Site A, but this amount is closer to the overall average for the tailings piles. The radium activities of the dune sand and the clay soil were quite low, but the clay loam soil had elevated levels (means significantly different at the 0.05 level using the approximate t-test for unequal variances). Extracts were prepared by various methods from a composite tailings sample to estimate available radium. The saturation paste was prepared following the method of Chapman and Pratt $(1961, p$. 13). The distilled water extract, the ammonium acetate extracts ( $\mathrm{pH} 7.0$ and 5.2), the first $\mathrm{CaCl}_{2}$ extract (1:10) and the DTPA (diethylenetriaminepentaacetic acid) extract (Khalid, Gambrell, and Patrick 1977) were prepared in the following manner: 1:10 dilution, equilibration of 4 hours with continuous mixing, centrifugation, and filtering through fine Whatman filter paper. The second $\mathrm{CaCl}_{\mathbf{2}} \mathrm{ex}$ tract (1:20) was performed using a 1:20 dilution and a 24-hour equilibration period (Francis 1978). The static leach was performed for 30 days using a 1:5 dilution (Wewerka et al. 1978). The second ammonium acetate extract at $\mathrm{pH} 7.0$ was prepared by a modification of Black's procedure (Black 1965) using multiple washes and centrifugation (Kelley 1979). The radium226 activities $(\mathrm{pCi} / \ell)$ in these extracts were then converted to the activity $(\mathrm{pCi} / \mathrm{g})$ extracted

Table 14. Comparison of extractable radium-226 activity ${ }^{1}$ (pCi/g dry weight) as calculated from extracts made by different methods on tailings from site $A$ used in greenhouse experiment

\begin{tabular}{|c|c|c|c|}
\hline Solution & Method & $\begin{array}{c}\text { Extractable } \\
\text { Ra-226 Activity }\end{array}$ & $\begin{array}{c}\text { Percentage } \\
\text { Extractable }^{2}\end{array}$ \\
\hline Distilled water & saturation paste & $3.0 \pm 1.3$ & 0.5 \\
\hline Distilled water & $1: 3$ dilution 4 & $3.0 \pm 2.0$ & 0.5 \\
\hline Distilled water & 1:10 dilution & $4.6 \pm 3.4$ & 0.8 \\
\hline $1 \mathrm{M} \mathrm{CaCl}_{2}$ & 1:10 dilution 6 & $3.6 \pm 2.3$ & 0.6 \\
\hline $1 \mathrm{M} \mathrm{CaCl}_{2}$ & $1: 20$ dilution ${ }^{8}$ & $12 \pm 5$ & 2.0 \\
\hline Distilled water & static leach & $54 \pm 1$ & 9.0 \\
\hline $0.05 \mathrm{M} \mathrm{DTPA}^{7}$ & $1: 10$ dilution & $60 \pm 4$ & 9.8 \\
\hline $\mathrm{NH}_{4} \mathrm{OAc},{ }^{\prime} \mathrm{pH} 7.0$ & 1:10 dilution 4 & $224 \pm 9$ & 37 \\
\hline $\mathrm{NH}_{4} \mathrm{OAc},{ }^{\circ} \mathrm{pH} 7.0$ & repeated wash ${ }^{\circ}$ & $310 \pm 10$ & 51 \\
\hline $\mathrm{NH}_{4} \mathrm{OAc},{ }^{8,10} \mathrm{pH} 5.2$ & $1: 10$ dilution 4 & $325 \pm 14$ & 53 \\
\hline
\end{tabular}

${ }^{1}$ Calculated value \pm analytical uncertainty.

${ }^{2}$ Extractable radium-226 activity divided by total radium-226 activity of tailings $(613 \pm 31$ $\mathrm{pCi} / \mathrm{g}$ dry weight (mean \pm one standard deviation) based on three measurements) times $100 \%$.

'Chapman and Pratt 1970.

Mixture was shaken for four hours.

-Francis 1978.

'Wewerka et al. 1978.

'Khalid, Gambrell, and Patrick 1977, p. 301.

1N ammonium acetate.

'Kelley 1979.

${ }^{10} \mathrm{pH}$ adjusted using glacial acetic acid. 
from the tailings. The results are presented in Table 14. The distilled water extracts contained the least radium. The static leaching and DTPA extracts were an order of magnitude higher. However, this extract of static leaching was acidified for filtration, which could have dissolved particulates; another extract of similar tailings from Site A which was not acidified showed only $<1 \%$ extractable, so this result of $9 \%$ may be unrealistically large. The increased contact between the ammonium acetate and the tailings in the modified Black's procedure with multiple wasling increased the radium extracted by $38 \%$. The acidity (5.2) of the ammonium acetate extract increased the radium extraction by $45 \%$ compared to the neutral $\mathrm{pH}$; these results indicate that the ammonium acetate extractions described for field samples may overestimate extractable radium. The $\mathrm{CaCl}_{2}$ solutions extracted relatively little radium. These may best represent the truly extractable radium since this extract was found to best simulate the soil solutions of calcium-saturated soils in studies of strontium uptake (Squire 1966). Thus only one to two percent of the total radium in these tailings may be available for plant uptake.

These resuits for availible radium agree with previous results on its leachability. For a prairie 30 il, a $1 \mathrm{~N}$ ammonium acetate extract removed $14 \%$ of the total radium (Hansen, Vidal, and Stout 1960). Shearer and Lee (1964) found $1.5 \%$ to $11 \%$ of the radium was leached by water for fine $(<105 \mu)$ and coarse $(300-590 \mu)$ tailings, respectively. In an experiment on desorption of radium from peat, Titaeva (1967) reported $4 \%$ leaching with water and $38 \%$ with $1 \mathrm{M}$ ammonium acetate. In mill tailings, 5 to $7 \%$ of the radium was leached using $\mathrm{CaCl}_{2}$ solutions of $\mathrm{pH} 7$ and $\mathrm{pH} 5$ respectively (Havlik, Grafova, and Nycova 1968); less than 1\% of the radium was leached from a uranium ore under the same conditions (Havlik, Nycova, and Grafova 1968). Ovchenkov (1972) reported low radium solubility in clay soils. A leaching experiment of three contaminated soils near a uranium refinery was done using static water leaching for 30 to 45 days; 5 to $40 \%$ of the radium was leachable with coarser soil fractions or coarser soils having greater leachability (Nathwani and Phillips 1978). Emanating radium (that fraction of the total radium which supplies radon to the soil gas) is comparable to exchangeable radium (Osburn 1965). These results are comparable to measurements of emanating radium, which has been reported to be $8 \%$ for soils (Clements and Wilkening 1974) and $20 \%$ for one tailings (Culot, Olson, and Schiager 1973). For blow sand in the Grants area, an emanating radium activity of $10 \mathrm{pCi} / \mathrm{g}$ was reported (Pearson and Jones 1966), compared to a total radium activity of $137 \mathrm{pCi} / \mathrm{g}$ (Dreesen and Marple, unpublished data, 1978). This implies an emanating fraction of less than $10 \%$. Thus, the percentage of radium leached varied greatly with extraction method, but the bioavailable radium in tailings is probably less than $10 \%$.

The plants were harvested after six months of growth. The biomass of aboveground shoots for each replicate of each treatment was determined and then replicates were composited as necessary for radium analysis. The results for shoct and radium activity are shown in Table 15. The biomass was usually slightly larger on the control treatments than on the tailings treatment for the sand and loam soils; the difference of greatest statistical significance $\mathbf{0 . 2}$ level in the approximate $t$-test) was that for the grass loam treatment. Overall, the biomass was greatest on treatments with loam soil and least on treatments with clay soil. The differences with the most statistical significance were from shrub tailings treatments: the biomasses from the loam and sand soils were significantly greater than that from the clay soil with $P<0.02$ and $P<0.2$ level, respectively, using the approximate $t$-test. The radium activity of the biomass from the control treatments was very similar to that measured in plants from local soils near sites A and B in New Mexico and near uranium areas in Wyoming (Winsor and Stahlecker 1974; Winsor and Whicker 1975). However, these activities are higher than those measured in four grass species grown in a potting soil in an environmental chamber; these plants had a mean activity of $0.24 \mathrm{pCi} / \mathrm{g}$ (Moffett and Tellier 1977). For both the grass and the 
Table 15. Aboveground biomass ${ }^{1}$ (g) and radium-226 activity ${ }^{1}$ ( $\mathrm{pCi} / \mathrm{g}$ dry weight) of Sporobolus airoldes and Atriplex canoscens grown in control soils and tailings in greenhouse experiment

\begin{tabular}{|c|c|c|c|c|}
\hline \multirow[b]{2}{*}{ Soil } & \multicolumn{2}{|c|}{ Sporobolue airoidos } & \multicolumn{2}{|c|}{ Atriplex canescens } \\
\hline & Control $^{2}$ & Tailings" & Control $^{2}$ & Tailings $^{8}$ \\
\hline Sand:biomass & $1.7 \pm 1.9(3)$ & $1.9 \pm 0.7(3)$ & $3.9 \pm 3.5(4)$ & $2.4 \pm 0.6(3)$ \\
\hline activity & $1.3 \pm 2.5(1)$ & $25 \pm 1.7(1)$ & $1.1 \pm 1.6(2)$ & $30 \pm 2.8(1)$ \\
\hline Loam:biomass & $3.6 \pm 1.4(3)$ & $1.9 \pm 0.9(3)$ & $3.9 \pm 1.4(2)$ & $2.7 \pm 0.4(4)$ \\
\hline activity & $3.1 \pm 0.2(2)$ & $2.9 \pm 1.4(1)$ & $2.9 \pm 1.5(1)$ & $12 \pm 1.5(1)$ \\
\hline Clay:biomass & $1.5 \pm 0.6(2)$ & $2.1 \pm 0.3(6)$ & $1 . \hat{o} \pm 0.5(3)$ & $1.8 \pm 0.5(6)$ \\
\hline activity & $2.7 \pm 3.9(1)$ & $9.4 \pm 3.6(2)$ & $1.8 \pm 1.8(1)$ & $48 \pm 4.9(1)$ \\
\hline
\end{tabular}

\footnotetext{
'( $n): n$ is number of samples; if $n=1$, measured value \pm analytical uncertainty; if $n>1$, inean activity \pm one standard deviation.

${ }^{2}$ Control treatment: soil alone.

Tailings treatment: soil over tailings; results for this treatment significantly greater than those for control troatment for shrub $(\mathrm{P}<0.025$ by analysis of variance) and for grass ( $P<0.2$ by Mann-Whitney test).
}

shrub, the radium activity in the biomass was directly related to the increasing activity of the soil (sand<clay<loam). The differences between the soil treatments was significant at the 0.01 level using analysis of variance. For all soils, the grass had somewhat higher activity than the shrub, but the differences were not significant. For the tailings treatments, the shrub had higher activities than the grass (significance of $\mathrm{P}<0.2$ using the Mann-Whitney test). The radium activity for the tailings treatment was significantly greater than that for control treatment for both the grass and shrub (significant with $\mathrm{P}<0.2$ in the Mann-Whitney test for the grass and with $\mathrm{P}<0.025$ by analysis of variance for the shrub). The greater radium uptake on the sand tailings treatment compared to the loam treatment for the shrub and both the loam and the clay treatments for the grass could be due to a greater transfer of radium from the tailings to the plants due to the lower cation exchange capacity of sand. Greater radium uptake by both alfalfa and a grass was reported from a soil lower in organic matter compared to two others (Grzybowska 1974). Waller and Dodd (1976) reported greater uptake (by 50 to $300 \%$ ) of radioactive calcium from a fine sandy loam compared with clay soil. Both grass and the shrub from the clay tailings treatment had higher radium content than those from the loam tailings treatment. Root growth was examined to explain some of these differences. Excavation of the pots at the conclusion of the experiment revealed generally poor root growth for both species because few roots penetrated the tailings. The root mass was not sufficient for radium analysis. The grass roots only grew one to two $\mathrm{cm}$ into the tailings, while a few small shrub roots grew all the way through the tailings. Most roots grew on the sides of the pots and underneath the filter paper which covered the hole at the bottom of the pot. The greater root mass of the shrub compared to the grass probably contributed to the higher radium values in the shrub on the tailings treatments. The plants in the sand tailings treatments had more and larger roots than those in the loam or clay tailings treatment. Large desiccation cracks in the clay allowed greater root penetration in the clay tailings treatment compared to the loam tailings treatment. Thus, variations in rooi growth were positively related to differences in radium activity of biomass from the tailings treatments. 
Table 16. Radium-226 activity ${ }^{1}$ ( $\mathrm{pCi} / \mathrm{g}$ dry weight), calcium concentration ${ }^{1}$ (percent), and radium:calcium ratio (pCi $\mathrm{Ra}-226 / 100 \mathrm{~g} \mathrm{Ca}$ ) in soils (both total and leachable') and aboveground shoots from greenhouse experiment

\begin{tabular}{|c|c|c|c|}
\hline & \multicolumn{3}{|c|}{ Soil } \\
\hline & Dune Sand & Clay Loam & Clay \\
\hline $\begin{array}{c}\text { Soil: leachable } \mathrm{Ra}-226 \\
\text { leachable } \mathrm{Ca} \\
\text { leachable ratio }\end{array}$ & $\begin{array}{r}0.02 \pm 0.001 \\
0.010 \pm 0.001 \\
2.0\end{array}$ & $\begin{array}{l}0.01 \pm 0.001 \\
0.017 \pm 0.002 \\
0.6\end{array}$ & $\begin{array}{l}0.04 \pm 0.001 \\
0.022 \pm 0.002 \\
1.8\end{array}$ \\
\hline $\begin{array}{c}\text { Soil: total } \mathrm{Ra}-226 \\
\text { total } \mathrm{Ca} \\
\text { total ratio }\end{array}$ & $\begin{array}{l}0.15 \pm 0.2(2) \\
1.7 \pm 0.1(2) \\
0.09\end{array}$ & $\begin{array}{r}2.7 \pm 0.5(2) \\
0.8 \pm 0.4(2) \\
3.38\end{array}$ & $\begin{array}{r}0.36 \pm 0.2(2) \\
2.5 \pm 0.1(2) \\
0.14\end{array}$ \\
\hline $\begin{array}{c}\text { Control` Spai` } \mathrm{Ra}-226 \\
\text { Spai Ca } \\
\text { Spai ratio } \\
\text { Atca }{ }^{3} \mathrm{Ra}-226 \\
\text { Atca Ca } \\
\text { Atca ratio }\end{array}$ & $\begin{array}{c}1.3 \pm 2.5(1) \\
0.35 \pm 0.03(1) \\
3.61 \\
1.1 \pm 1.6(2) \\
3.1 \pm 0.1(1) \\
0.35\end{array}$ & $\begin{array}{c}3.1 \pm 0.2(2) \\
0.41 \pm 0.04(1) \\
7.56 \\
2.9 \pm 1.5(1) \\
2.8 \pm 0.1(1) \\
1.04\end{array}$ & $\begin{array}{c}2.7 \pm 3.9(1) \\
0.53 \pm 0.03(1) \\
5.09 \\
1.8 \pm 1.8(1) \\
3.9 \pm 0.1(1) \\
0.46\end{array}$ \\
\hline $\begin{array}{l}\text { Tailings }{ }^{8} \text { Spai } \mathrm{Ra}-226 \\
\text { Spai } \mathrm{Ca}^{7} \\
\text { Spai ratio } \\
\text { Atca } \mathrm{Ra}-226 \\
\text { Atca } \mathrm{Ca}^{7} \\
\text { Atca ratio }\end{array}$ & $\begin{aligned} 25 & \pm 1.7(1) \\
0.29 & \pm 0.02 \\
86 & \\
30 & \pm 2.8(1) \\
2.5 & \pm 0.1 \\
12.2 & \end{aligned}$ & $\begin{array}{l}2.9 \pm 1.4(1) \\
0.18 \pm 0.02 \\
16 \\
12 \pm 1.5(1) \\
2.1 \pm 0.1 \\
5.7\end{array}$ & $\begin{aligned} 9.4 & \pm 3.6(2) \\
0.37 & \pm 0.02 \\
25 & \\
48 & \pm 4.9(1) \\
3.8 & \pm 0.1 \\
12.5 & \end{aligned}$ \\
\hline
\end{tabular}

${ }^{2}(n): n$ is number of samples; if $n=1$, measured value \pm analytical uncertainty; if $n>1$, mean activity \pm one standard deviation given.

${ }^{2}$ Static/equilibrium leaching; $n=2$.

${ }^{s}$ Control treatment: one of the three soils alone was the substrate.

'Spai: Sporobolus airoides.

'Atca: Atriplex canescens.

Tailings treatment: a layer of one of the three soils over tailings was the substrate. ${ }^{2} \mathbf{n}=1$.

In order to better understand the influence of calcium on radium uptake and the,different radium contents seen in the plant tissues, calcium analyses were performed on the plant samples, substrate samples, and substrate leachates. The leachates were produced by a static leach procedure of shaking a 1:5 mixture of the solids and distilled water for 30 days and subsequent filtration through millipore filters (Wewerka et al. 1978). The calcium analyses were done by instrumental thermal neutron activation analysis for the substrates and by flame atomic absorption for the leachates and vegetation. The results of these analyses with corresponding radium activities and radium:calcium ratios are shown in Table 16 . The tailings had a total calcium content of $5.7 \pm 0.1 \%$ and a leachable calcium content of $0.001 \%$. The total radium activity of the tailings was $613 \mathrm{pCi} / \mathrm{g}$, and the leachable activity was $54 \mathrm{pCi} / \mathrm{g}$, as 
described earlier. Thus the radium:calcium ratios for the tailings were 540 and $108 \mathrm{pCi} / \mathrm{g} \mathrm{Ra}$ $226 / 100 \mathrm{~g}$ calcium for leachable and total, respectively. The higher total calcium concentration of the clay are reflected in higher calcium content of the plants grown in this soil for both control and tailings treatments. The shrub contained significantly more calcium (by as much es an order of magnitude) than the grass on both treatments. The calcium concentrations in the plants from the tailings treatment were somewhat less than those of the control treatment for both species on all soils, despite the high calcium content of the tailings. The radium:calcium ratio is directly related to the total substrate ratio, but inversely related to the leachable ratio. The leachable radium and calcium contents compared to the total contents varied for the soils; the radium in the sand and clay was about $10 \%$ leachable, but $0.2 \%$ of that in the loam was leachable. But loam had the greatest percentage of leachable calcium (2\%) compared to less than $1 \%$ for the sand and clay. These factors of lower radium leachability and high calcium leachability probably contributed to the lower radium content of both species on loam tailings treatment.

A variation of the loam tailings treatment for the shrub was performed in order to evaluate the effectiveness of a clay barrier between the soil and tailings. A $2.5 \mathrm{~cm}$ layer of bentonite clay was placed on top oi the tailings and below $5 \mathrm{~cm}$ of clay loam soil in six replicate pots. All six pots showed more vigorous growth than any of the other shrub treatments. The results for bicmass and radium activity of these shrubs are shown in Table 17 . The vigorous growth resulted in significantly $(\mathrm{P}<0.01)$ greater biomass for the barrier treatment than that for the tailings treatment These plants also had higher radium activity, which partially reflect i : 22 elevated radium content of the bentonite clay $(4.7 \pm 0.7 \mathrm{pCi} / \mathrm{g}$, the result of one mesw.

ment). Excavation of the pots revealed that the clay barrier had disintegrated and that these shrubs had more extensive roots in the tailings than those of the tailings treatment. These results indicate that a thin clay barrier may not be effective as a hindrance to uptake of contaminants from tailings unless it is sufficiently compacted to prevent root penetration. In this case, the radium activity of the shrub biomass from the barrier treatment was significantly greater than that of the control treatment ( $\mathrm{P}<0.1$ using the approximate t-test). However, $\mathrm{a}$ clay barrier can benefit plant growth due to the clay's large capacity for water retention and

Table 17. Comparison of aboveground biomass ${ }^{1}$ (g) and radium-226 activity ${ }^{1}$ (pCi/g dry weight) of Atriplex canescens in three treatments from the greenhouse experiment

Treatment

\begin{tabular}{|c|c|c|c|}
\hline & Control & Tailings & Barrier \\
\hline Substrate & Soil ${ }^{2}$ & Soil/Tailings & Soil/Barrier/Tailings \\
\hline Biomass & $3.9 \pm 1.4(2)$ & ${ }^{3} 2.7 \pm 0.4(4)$ & ${ }^{3} 4.5 \pm 0.9(6)$ \\
\hline Activity & ${ }^{4} 2.9 \pm 1.5(1)$ & $12 \pm 1.5(1)$ & ${ }^{4} 18 \pm 3.9(3)$ \\
\hline
\end{tabular}

\footnotetext{
${ }^{2}(n): n$ is number of replicates; if $n=1$, measured value \pm analytical uncertainty; if $n>1$. mean activity \pm one standard deviation.

${ }^{2}$ Clay loam soil.

'Means significantly different at the 0.01 confidence level using approximate t-test.

'Means significantly different at the 0.1 confidence level using $t$-test.
} 
Table 18. Comparison of mean radium-226 activity (pCi/g dry weight) in aboveground shoots and associated substrates from field sites and greenhouse experiment

\begin{tabular}{|c|c|c|c|c|}
\hline \multirow[b]{2}{*}{ Sample } & \multirow[b]{2}{*}{ Substrate } & \multirow[b]{2}{*}{ Substrate Activity } & \multicolumn{2}{|c|}{ Shoot Activity" } \\
\hline & & & $\begin{array}{c}\text { Sporobolus } \\
\text { airoides }\end{array}$ & $\begin{array}{l}\text { Atriplex } \\
\text { canescense }\end{array}$ \\
\hline Field sites & bare tailings & $389 \pm 310(14)$ & $35 \pm 15(2)$ & $17 \pm 14(7)^{a . b}$ \\
\hline Field sites & covered tailings & $503 \pm 376(7)$ & $13 \pm 15(6)$ & $3.0 \pm 3.1(5)^{2 . c}$ \\
\hline Experiment & covered tailings & $613 \pm 31(3)$ & $12 \pm 9.6(4)^{d}$ & $24 \pm 13(6)^{c . \bullet}$ \\
\hline Experiment & control soils & $1.1 \pm 1.3(6)$ & $2.6 \pm 0.9(4)^{d}$ & $1.7 \pm 1.2(4)^{\bullet}$ \\
\hline Field sites & local soils & $1.9 \pm 0.5(6)$ & $2.0 \pm 1.0(1)$ & $0.8 \pm 0.5(4)^{\mathrm{b}}$ \\
\hline
\end{tabular}

${ }^{1}(n): n$ is number of samples; if $n=1$, measured activity \pm analytical uncertainty; if $n>1$, mean activity \pm one standard deviation.

${ }^{2}$ Mean significantly different $(P<0.05)$ if followed by some letter (except for $d$ where $P<0.1$ ).

cation exchange, as evidenced in the increased biomass on the barrier treatment.

The radium content of the aboveground vegetation from this experiment and from the field sites described earlier are presented in Table 18. All results from Sites $A$ through $S$ are included in the means given. The control samples from the experiment had slightly higher activities than the background samples from the field sites. In both cases, the grass had higher activities than the shrub. The grass from the covered tailings treatment of the experiment had very similar levels compared with samples from covered tailings at field sites and had significantly $(\mathrm{P}<0.1)$ greater radium content than the grass from the control soils. The shrub had higher activities in the experiment than in the field possibly because of better growth conditions under the irrigating and fertilizing regime. The shrub samples from the tailings treatment in the greenhouse experiment and from bare tailings at field sites had significantly greater $(P<0.05)$ radium content than the samples from covered tailings at field sites and from soils. Better growth conditions could also have contributed to the slightly higher radium226 content of the greenhouse controls compared to the field samples from local soils. Thus, both Sporobolus and Atriplex had radium contents 5 to 19 times control levels in the absence of surficial contamination in the greenhouse experiment, and these activities are similar to those measured in field samples. 


\section{SUMMARY AND CONCLUSIONS}

The measurement of radium content of plants and substrates at inactive uranium mill sites showed a wide range of results. For substrates, the radium content is inversely related to texture because the fine fraction $(<53 \mu \mathrm{m})$ contains 2 to 10 times as much radium as the coarser fractions (Moffett and Tellier 1978; Dreesen and Wienke 1978). Since many tailings piles are not well homogenized, there are wide variations in texture and radium activity. Most tailings had activities which were 100 to 500 times those of local soils. These variations in texture and activity of the substrate could result in great differences in surficial contamination. In a previous comparison of three inactive sites, Breslin and Glauberman (1970) found Site A to have by far the largest flux and activity of resuspended particulates. In comparison with Site B, Site A also had more particle creep and saltation with higher radium content in collected particles despite little difference in mean tailings activities (Marple, Barr, and Dreesen 1978). Thus, the estimates of surficial contamination made at Site A may be upper limits for all sites. For instance, Kotsch (1977) found little surficial contamination in plants downwind from a tailings pile. The amount of surficial contamination may be quite different among plant species, depending on leaf characteristics (presence of hairs or glands) and specific location. The use of some cleaning method for plant samples in this study was desirable to determine the true tissue content. Air-cleaning was simpler and did not change elemental composition of the sample; however, it was less effective and more variable than water-cleaning. For some samples, air-cleaning removed none of the surficial contamination. The major disadvantage with water-cleaning was the potential of leaching elements from the tissue. Since radium in plant tissues is relatively insoluble in water (Kirchmann, Koncucci, and Mousny 1965), this was not a large effect, but it might be for more soluble elements. Sodium and manganese are two such elements which were found to be easily leached from leaves (Tukey, Wittwer, and Tukey 1958). Water-cleaning is more effective than air-cleaning, especially with very dirty plant samples such as roots. Thus, water-cleaning would be recommended for samples to be analyzed for elements with low water solubility. With this method, 30 to $75 \%$ of the surficial contamination can be removed, 'depending on plant species and parts.

The measurements of radium in plant samples from Sites $A$ and $B$ showed elevated levels for all species. The shrub Atriplex often had lower total content than the other species and the forbs Kochia and Salsola often had the highest activities. If the estimates of higher surficial contamination of Atriplex were considered, the differences were sven greater. The plants at Site A consistently grew in coarser tailings of lower than average radium content; little growth was seen in the finer tailings. The soil overburden on the covered tailings at Site $B$ had greater radium content than local soils due to contamination by wind-blown particulates and by capillary rise from the tailings below; the plants from the covered tailings had higher activities than those from local soils. The differences in radium content between plant parts varied with species and location; in general, the variation was a factor of 1.5 to 5.0 , but no consistent order of activity among parts was observed. For selected samples analyzed for calcium, the uptake of radium was shown to be inversely related to calcium content in the substrate. Lower percentages of radium are leachable in soils with higher calcium and magnesium contents (Rusanova 1962). This factor could influence the bioavailability of radium on substrates which are typically high in calcium, such as soils of the Southwest and alkaline uranium miil tailings. The activities of plant samples from these sites compare well to those reported elsewhere for tailings areas in New Mexico and Wyoming (Holtzman et al. 1979; Kotsch 1977; 
Whicker 1978; Kennington and Doerges 1978). Similar values were reported for grass growing on sludged tailings (Schmidtke et al. 1978).

The survey of 18 inactive uranium mill sites in the Four Corners Region included both covered and uncovered tailings piles. The radium content of plants growing on uncovered tailings were generally lower than those at Sites A and B. Most of these sites had been revegetated with irrigation and fertilization (Beverly 1968) and the irrigation could have leached the soluble radium from the surface of the tailings. The use of fertilizers has been shown to reduce radium mobility and its uptake by plants (Rusanova 1972). Therefore, the revegetation process could decrease the bioavailability of radium. For covered piles, the soil overburden cor tained 2 to 10 times as much radium as local soils. Similar results were found in the USSR at a site covered by 20 to $50 \mathrm{~cm}$ of sand and gravel, where the tailings contained $2000 \mathrm{pCi} / \mathrm{g}$ and the soil cover had $350 \mathrm{pCi} / \mathrm{g}$; plants there were allowed to colonize naturally, and after three to five years, the plants contained 1 to $2 \mathrm{pCi} / \mathrm{g}$ dry weight on the covered area as compared with $5 \mathrm{pCi} / \mathrm{g}$ before covering (Maslov, Gruzdev, and Maslova 1969). On covered tailings piles in the Four Corners Region, the radium content of the plants ranged from background levels to 20 times background. Extractable radium was measured using ammonium acetate (1N, pH 5.2) extraction of tailings. The extractable radium activity was usually 50 to $65 \%$ of the total activity, but it was not closely related to the radium content of the plants growing in the tailings.

In general, the radium content of these plants from the inactive uranium mill sites in the Four Corners Regions are somewhat higher than those reported from other areas. The chemical form of radium in tailings as opposed to spiked soils could account for some of these differences. The radium was generally associated with the organic fraction in soils (Titaeva 1967) but the organic content of mill tailings is usually very low. Grybowska (1974) reported greater radium uptake by plants growing in soils with low organic matter content. Thus, the relatively high radium activity of plants growing on inactive tailings piles could be due to the low organic matter content of the substrate and subsequent low radium retention.

The results from inactive tailings sites can be compared with other uranium studies. Downstream from a uranium mill in Colorado, the radium activities were $40-50 \mathrm{pCi} / \mathrm{g}$ for soils and $1 \mathrm{pCi} / \mathrm{g}$ for alfalfa (Tsivoglou 1964). Four grasses growing on revegetated mill tailings (with $200 \mathrm{pCi} / \mathrm{g}$ ) had a mean radium activity of $5.5 \mathrm{pCi} / \mathrm{g}$ (Moffett and Tellier 1977). In an area of high natural radioactivity in Iran, plant activities ranged from 0.1 to $70 \mathrm{pCi} / \mathrm{g}$ as soils varied from 17 to $9000 \mathrm{pCi} / \mathrm{g}$ (Khademi, Alemi, and Nasseri 1980). In areas of releases from uranium ore processing plants had activities up to $100 \mathrm{pCi} / \mathrm{g}$ while soils were 10 to 1000 times background (Titaeva et al. 1980). In phosphate mining areas, overburden over tailings had elevated radium activities $(19 \mathrm{pCi} / \mathrm{g})$ compared to top soil $(0.6 \mathrm{pCi} / \mathrm{g})$; some debris lands from earlier mining contain 3-25 pCi/g (Roessler et al. 1980). Thus activities measured from inactive sites in the Four Corners Region were similar to other regions for substrate activity, but generally higher for vegetative activity. However, a direct relationship between plant and soil content was often not found either for radium in these studies or for other contaminants (Kelley 1979; Kidd and Potter 1978). Many soil factors such as calcium content, pH, and cation exchange capacity affect the bioavailability of radium to plants. Grasses grown on slimes (314 $\mathrm{pCi} / \mathrm{g}$ ) did not have higher radium activity than those grown on sands with $166 \mathrm{pCi} / \mathrm{g}$ (Moffett and Tellier 1977). Similarly, for large increases in natural soil activity (factors between 17 and 43), increases of 3 to 15 times in activity of vegetables were measured (Khademi, Alemi, and Nasseri 1980). Thus, for small (factor of two) differences in the substrate activity, a direct relationship with plant radioactivity is not evident.

The greenhouse experiment showed significant radium uptake by two native species grown on soil-covered tailings. The species were a grass, Sporobolus airoides, and a shrub, Atriplex canescens. Under conditions of minimal surficial contamination and fertilization, the 
aboveground biomass of plants grown on soil-covered tailings had significantly higher radium content than that from control plants grown in soils alone. The shrub absorbed more radium than the grass due to better root penetration into the tailings. Three soils, dune sand, clay loam, and clay, were used for the cover material and for the controls. The radium content of control plants for both species was positively related to the radium content of the soils. The radium activity of the biomass for both the control and the tailings treatment are similar to, or sometimes slightly greater than, that measured in the same species growing at inactive uranium mill sites and adjacent areas.

In conclusion, radium content of native and naturalized plant species growing at inactive uranium mill sites was shown to be significantly greater than that of local plants. This was shown on both covered and uncovered tailings and on local soils with elevated radium contents. Similar values were found in two species grown on soil-covered tailings in a greenhouse. Thus radium is absorbed and translocated by plants and this could be a significant mechanism of dispersal in the environment. Radium is a contaminant in all uranium mill tailings unless removed by leaching with nitric acid. Even if tailings are buried beneath deep ( $3 \mathrm{~m}$ ) soil overburdens, biological penetration of the cover by plant roots of deep-rooted plant species such as Atriplex canescens (Kearney and Peebles 1973) and burrowing animals could introduce radium into the food chain (Whicker 1978). The possibility for plant absorption of contaminants from deep $(5 \mathrm{~m}$ ) ore deposits has already been described by Cannon (1952). Thus, radium uptake by plants growing over buried uranium mill tailings could still be of concern. In addition, any dispersal by wind or water of tailings into the environs of the tailings pond would introduce radium into the food chain. Kotsch (1977) found increased levels of radium activity in soils and plants downwind from an active tailings pile. Areas of increased radium activity were also found up to $800 \mathrm{~m}$ away from uranium mines and mills (Winsor and Stahlecker 1974; Winsor and Whicker 1975). Since it is difficult to avoid dispersal of tailings into the environment around an active uranium mill, the uptake of radium by plants growing near a mill is a continuing source of its entry into the food chain. Similar problems of dispersal are found with some mine spoils from uranium mines, with storage of uranium ores, and with phosphate mining. Thus, radium can be enhanced in the environment by these activities. Estimates of the radiation dose to man in areas of uranium mining and milling have been quite small (Winsor and Whicker 1975; Holtzman et al. 1979). However, more information is needed to evaluate reduction of contamination with distance from the mill area and to evaluate the radium levels in large herbivores, such as antelope, sheep, and cattle. This study provides a basis for estimating intake levels for such animals and for evaluating transfer coefficients. Additional information for a larger number of species and for different tailings materials and soils would be useful in making these estimates. This study showed the bioavailability of radium for plant uptake by several native and naturalized species growing at diverse uranium mill sites throughout the Four Corners Region of the southwestern United States. 


\section{ACKNOWLEDGMENTS}

I thank Loren D. Potter for his support and encouragement throughout this study. I am grateful to Rex G. Cates and James R. Gosz for their advice during this project. I appreciate the assistance of Wayne $C$. Hanson and Gordon V. Johnson.

I am indebted to Los Alamos Scientific Laboratory (Grant No. W-7405-ENG36) for supporting this work. Special thanks go to William E. Goode for performing gamma-spectroscopy and to $\mathrm{H}$. Maxine Lewis for typing the manuscript. I thank Ernest S. Gladney and James W. Owens for performing neutron activation and atomic absorption analysis. I am grateful to David $R$. Dreesen for helpful comments throughout the study.

I appreciate the support and aid of the uranium industries who permitted access to their property. I thank N. E. Kelley for assistance in field work.

I am indebted to Cyrus D. Cantrell for encouragement and moral support throughcut this undertaking. 


\section{SELECTED BIBLIOGRAPHY}

Agulhon, H. and T. Robert. 1915. Contribution d l'étude de l'áction du radium et son émanation sur la germination des végétaux supérieurs. Ann. Inst. Pasteur 29:261-73.

Aleksakhin, R.M. 1971. Migration of natural radionuclides and their effects in terrestrial biogeocenoses. Ekologiya 2:582-83.

Aleksakhin, R.M. and V.D. Vasil'yevskaya. 1960. The second interuniversity conference on the problem of microelements and the natural radioactivity of USSR soils. Pochuovedenie (9):1013-14.

Alexander, L.T. 1950. Radioactive materials as plant stimulants-Field results. Agronomy Journal 42:252-55.

Anderson, J.B., E.C. Tsivoglou, and S.D. Shearer. 1963. Effects of uranium mill wastes on biological fauna of the Animas River (Colorado-New Mexico). In Radioecology, eds. V. Schultz and A.W. Klement, Jr., pp. 373-83. New York:Reinhold.

Auerbach, S.I. 1958. The soil ecosystem and radioactive waste disposal to the ground. Ecology 39:522-29.

Bakhurov, V.G., I.K. Lutsenko, and N.N. Shashkina. 1965. Radioaktivnye Otkhody Uranovykh Zavodov. Moscow: Atomizdat.

Baltakmens, T. 1974. Profiles of lead-210 and radium-226 in four New Zealand soils. New Zealand J. Sci. 17:435-39.

Baranov, V.I. 1939. Assimilation of radioactive elements by plants. Doklady Akad. Nauk SSSR 24:951-54.

Baranov, V.I., N.G. Morozova, K.G. Kunasheva, and G.I. Grigor'yev. 1963. Geochemistry of some natural radioactive elements in soil. Pochvovedenie (8):733-40.

Baranov, V.I. and N.G. Morozova. 1969. General regularities of natural radioisotope distribution in soils of the USSR. In Actes du Symposium International de Radioecologie, Vol. 1, pp. 469-89. Cadarache:Centre d'Etudes Nucléaires.

-1973. Behavior of natural radionuclides in soil. In Radioecology, eds. V.M. Klechkovskii, G.G. Polikarpov, and R.M. Aleksakhin, pp. 3-29. New York:John Wiley and Sons.

Beauford, W., J. Barber, and A.R. Barringer. 1977. Release of particles containing metals from vegetation into the atmosphere. Science 195:571-73.

Becquerel, H. 1901. Sur quelques effets chimiques produits par le rayonnement du radium. Comptes Rendus 133:709-12. 
Belova, R.S. and Z.P. Lun'kina. 1967. The content of radium and uranium in foodstuffs and their accumulation in human teeth. Gig. Sanit. (6):48-51.

Beverly, R.G. 1968. Unique disposal methods are required for uranium mill waste. Mining Eng. 20(6):52-56.

Bhujbal, B.M., T.J. D'Souza, and K.B. Mistry. 1972. Discrimination between radium and calcium in the soil-plant system. In Radiation and Radioisotopes in Soil Studies and Plant Nutrition, ed. V.A. Kamrak, pp. 155-65. Bombay:Dept. of Atomic Energy.

Biddulph, O. 1960. Radioisotopes in plants: Foliar entry and distribution. In Radioisotopes in the Biosphere, eds. R.S. Caldecott and L.A. Snyder, pp. 73-85. Minneapolis:Univ. of Minnesota.

Bittel, R., N. Fourcade, and P. Zettwoog. 1978. Remarques au sujet de la stabilisation des stériles de l'industrie de l'uranium par implantation de végétation. Paper read at Seminar on Management, Stabilisation, and Environmental Impact of Uranium Mill Tailings, 24-28 July 1978, at Albuquerque, New Mexico.

Black, C.A., ed. 1965. Methods of Soil Analysis. Agronomy Series, no. 9. 2 vols. Madison:Amer. Soc. of Agronomy.

Bowen, H.J.M. 1966. Trace Elements in Biochemistry. New York:Academic Press.

Bowen, H.J.M. and J.A. Dymond. 1956. The uptake of calcium and strontium by plants from soils and nutrient solutions. J. Exp. Bot. 7:264-72.

Brendakov, V.F., S.V. Iokhel'son, and V.N. Churkin. 1967. Potassium, radium, and thorium content on the upper layer of soils of the Caucasus. Pochvovedenie (1):31-36.

Breslin, A.J. and H. Glauberman. 1970. Investigation of radioactive dust dispersed from uranium tailings piles. In Environmental Surveillance in the Vicinity of Nuclear Facilities, ed. W.C. Reinig, pp. 249-53. Springfield:Charles C. Thomas.

Brooks, R.R. 1972. Geobotany and Biogeochemistry in Mineral Exploration. New York:Harper and Row.

Brown, Roger C. 1974. Evidence of seasonal effects on environmental radioactivity. J. Env. Sci. 17:25-26.

Brunovskij, B. and K. Kunaŝeva. 1930. Sur la teneur en radium de quelque plantes. Doklady Akad. Nauk SSSR Ser A:537-38.

Cannon, H.L. 1952. The effect of uranium-vanadium deposits on the vegetation of the Colorado Plateau. Am. J. Sci. 250:735-70.

-_1953. Geobotanical reconnaissance near Grants, New Mexico. U.S. Geol. Survey Circ. 264.

1954. Botanical methods of prospecting for uranium. Mining Eng. 6(2):217-20. 
Carter, L.J. 1978. Uranium mill tailings: Congress addresses a long-neglected problem. Science 202:191-95.

Cataldo, D.A. and B.E. Vaughan. 1977. Retention, absorption, and translocation of foliar contaminants. In Transuranics in Natural Environments, eds. M.G. White and P.B. Dunaway, pp. 331-49. Springfield:NTIS NVO-178.

Chapman, H.D. and P.F. Pratt. 1961. Methods of Analysis for Soils, Plants, and Waters. Berkeley:Univ. of California Division of Agricultural Science.

Clark, D.A. 1974. State-of-the-art: Uranium mining, milling, and refining industry. U.S. Environmental Protection Agency report EPA-660/2-74-038.

Clements, W.E. and M.H. Wilkening. 1974. Atmospheric presirure effects on ${ }^{222}$ Rn transport across the earth-air interface. J. Geophys. Res. 79:5025-29.

Culot, M.V.J., H.G. Clson, and K.J. Schiager. 1973. Radon progeny control in buildings. Final report on research supported by the U.S. Environrnental Protection Agency (Grant No. ROIEC00153) and the U.S. Atomic Energy Commission (Contract No. AT(11-1)-2273).

de Bortoli, M. and P. Gaglione. 1972. Radium-226 in environmental materials and foods. Health Physics 22:43-48.

Delpoux, M. 1969. Comparaison des teneurs en radium et uranium de végétaux récoltes sur des terrains uraniferes. In Actes du Symposium International de Radioecologie, vol. 2, pp. 909-21. Cadarache:Centre d'Etudes Nucléaires.

Dixon, H.H. 1903. Radium and plant:. Nature 69:5.

Donovan, R.P., R.M. Felder, and H.H. Rogers. 1976. Vegetative stabilization of mineral waste heaps. U.S. Environmental Protection Agency report EPA-600/2-76-087.

Dreesen, D.R. and C.L. Wienke. 1978. Gross alpha activity as an estimator of radium-226 activity in soils and tailings at an inactive uranium mill tailings site. Los Alamos Scientific Laboratory report LA-7529-MS.

Drobkov, A.A. 1937. The influence of the radioactive elements uranium, radium, thorium, and actinium on the yield of plants. Doklady Akad. Nauk SSSR 17:229-32.

1941. Effect of radioactive elements (Ra) and rare earths (TR) upon yield and rubber content of Kok-saghyz. Doklady Akad. Nauk SSSR 32:667-68.

- 1949. Influence of radioactive elements upon the lives of plants. U.S. Department of the Army translation.

D'Souza, T.J. and K.5. Mistry. 1970. Comparative uptake of thorium-230, radium-226, lead210, and polonium-210 by plants. Rad. Bot. 10:293-96.

Eadie, G.G., R.F. Kaufmann, D.J. Markley, and R. Williams. 1976. Report of ambient outdoor radon concentrations during November 1975 at selected locations in the Grants Mineral Belt, New Mexico. U.S. Environmental Protection Agency technical note ORP/LV-76-4. 
Eberharait, L.L. 1976. Sampling for radionuclides and other trace substances. In Radioecology and Energy Resources, ed. C.E. Cushing, Jr., pp. 199-208. Stroudsburg:Dowden, Hutchinson, and Ross.

Eisenbud, M. and H.G. Petrow, 1964. Radioactivity in the atmospheric effluents of power plants that use fossil fuels. Science 144:288-89.

Eisenbud, M., H. Petrow, R.T. Drew, F.X. Roser, G. Kegel, and T.L. Cullen. 1964. Naturally occurring radionuclides in foods and waters from the Brazilian areas of high radioactivity. In The Natural Radiation Environment, eds. J.A.S. Adams and W.M. Lowder, pp. 837-54. Chicago: Univ. of Chicago Press.

Epstein, E. 1972. Mineral Nutrition of Plants:Principles and Perspectives. New York:John Wiley and Sons.

Epstein, E. and J.E. Leggett. 1954. The absorption of alkaline earth cations by barley roots:Kinetics and mechanism. Am. J. Bot. 41:785-91.

Fisenne, I.M. 1967. Distribution of lead-210 and radium-226 in soil. In Proceedings of the 13th Meeting on Bioassay and Analytical Chemistry, pp. 145-58. New York:Atomic Energy Commission UCRL-18140.

Francis, C.W. 1978. Radiostrontium movement in soils and uptake in plants. U.S. Department of Energy TID-27564.

Francis, C.W., S.S. Talmage, and B.B. McMullin. 1975. Radionuclide movement in soils and uptake by plants: A selected, annotated bibliography. U.S. Energy Research and Development Administration report ORNL-EIS-75-77.

Gadgil, Ruth L. 1969. Tolerance of heavy metals and the reclamation of industrial wastes. $J$. Appl. Ecol. 6:247-59.

Gager, C.S. 1908a. Effects of the rays of radium on plants. Mem. N.Y. Bot. Garden 4:1-278.

__ 1908b. Some physiological effects of radium rays. Am. Nat. 42:761-78.

1936. The effects of radium rays on plants. In Biological Effects of Radiation, ed. B.M. Duggar, pp. 987-1013. New York:McGraw-Hill.

Gager, C.S. and A.F. Blakeslee. 1927. Chromosome and gene mutations in Datura following exposure to radium rays. Proc. Nat. Acad. Sci. 13:75-79.

Gedeonov, L.I., S.P. Rosyanov, and V.K. Vinogradova. 1967. Effect of herbaceous vegetation on the radioactive contamination of the soil. Pochuovedenie (10):1394-96.

Gesell, T.F. and H.M. Prichard. 1975. The technologically enhanced natural radiation environment. Health Physics 28:361-66.

Gopal-Ayengar, A.R. and K.B. Mistry. 1962. On the radioactivity of plants from the high radiation areas of the Kerala Coast and adjoining regions: 1 . Studies on the uptake of gamma- 
emitting radionuclides. In Radioisotopes in Soil-Plant Nutrition Studies, pp. 3-16. Vienna:International Atomic Energy Agency.

Green, J.H. and E.T. Fallister. 1965. Radiochemical analyses for strontium-90, cesium-137, radium-226, and potassium-40 in natural and processed materials in Australia. Aus. J. Sci. 27:199-202.

Grossman, A., J. Kwapulinski, and K. Lukasik. 1973. Concentration of ${ }^{220} \mathrm{Ra}$ in the region of Katowice. Nukleonika 18:53-56.

Gruzdev, B.I. and D.M. Rubtsov. 1972. Accumulation of thorium, uranium, and radium by plants and organogenous horizons of soils. In Radioekologicheskie Issledovaniya v Prirodnykh Biogeotsenozakh, ed. I.N. Verkhovskaya, pp. 112-23. Moscow:Izdatel'stvo Nauka.

Grzybowska, D. 1974. Uptake of "Ra by plants from contaminated soils. Nukleonika 19:7178.

Grzybowska, D. and S. Wlodek. 1972 . Contribution a l'étude du transfert de ${ }^{\circ} \mathrm{Sr}$, ${ }^{117} \mathrm{Cs}$, et wRa de sol vers les plantes. In Radioecology Applied to the Protection of Man and His Environment, vol. 2, pp. 1069-79. Rome:Commission of the European Communities CONF. 710973.

Guilleminot, H. 1907. Effets comparés des rayons $\mathrm{X}$ et du radium sur la cellule végétale: Valeur de l'unité $\mathrm{M}$ en physiologie végétale. Comptes Rendus 145:798-800.

Gunn, K.B. and K.B. Mistry. 1970. The effect of chelating agents on the absorption of radium by plants. Plant and Soil 33:7-16.

Gvozdanovic, S.M., T.R. Overton, and F.W. Spiers. 1967. A study of the concentrations of ${ }^{N_{R}}$ and ${ }^{2}$ Th in the living environment. In The Determination of Radionuclides in Materials of Biological Origin, ed. A. Holmes, pp. 175-89. Harwell:Atomic Energy Research Establishment AERE-R5474.

Hallden, N.A., I.M. Fisenne, and J.H. Harley. 1963. Radium-226 in human diet and bone. Science 140:1327-29.

Hallden, N.A. and J.H. Harley. 1964. Radium-226 in diet and human bone from San Juan, Puerto Rico. Nature 204:240-41.

Hansen, R.O. 1970. Radioactivity of a California terrace soil. Soil Sci. 110:31-36.

Hansen, R.O., R.D. Vidal, and P.R. Stout. 1960. Radioisotopes in soils: Physical-chemical composition. In Radioisotopes in the Biosphere, eds. R.S. Caldecott and L.A. Snyder, pp. 2336. Minneapolis:Univ. of Minnesota.

Hanson, W.C. 1980 in press. Ecological considerations of natural and depleted uranium. In The Natural Radiation Environment III, eds. T.F. Gesell, W.M. Lowder, and J.E. McLaughlin.

Harrington, H.D. 1964. Manual of the Plants of Colorado. 2nd ed. Chicago:The Swallow Press, Inc. 
Havlik, B. 1970. Radioactive pollution of rivers in Czechoslovakia. Health Physics 19:617-24. 46:490-505.

Havlik, B., J. Grafova, and B. Nycova. 1968. Radium-226 liberation from uranium ore processing mill waste solids and uranium rocks into surface streams-I. The effect of different $\mathrm{pH}$ of surface waters. Health Physics 14:417-22.

Havlik, B., B. Nycova, and J. Grafova. 1968. Radium-226 liberation from uranium ore processing mill waste solids and uranium rocks into surface streams. - II. The effect of different chemical composition of surface water. Health Physics 14: 423-30.

Havlik, B. and E. Robertson. 1971. Radium uptake by freshwater algae. In Radionuclides in Ecosystems, ed. D.J. Nelson, sol. 1, pp. 372-80. Springfield:NTIS CONF-710501-P1.

Healy, J.W. and J.C. Rodgers. 1978. A preliminary study of radium-contaminated soils. Los Alamos Scientific Laboratory report LA-7391-MS.

Hébert, A. and A. Kling. 1909. De l'influence des radiations du radium sur les fonctions chlorophylliene et respiratoire chez les végétaux. Comptes Rendus 149:230-32.

Hill, C.R. 1960. Lead-210 and polonium-210 in grass. Nature 187:211-12.

Hollins, J.G. 1977. Radium in vegetable gardens. In The Proceedings of IVth International Congress of International Radiation Protection Association, ed. G. Bresson, vol. 3, pp. 104548. Montreuil:Imprimerie Gauthier-Villars.

Holtzman, R.B. 1966. Natural levels of lead-210, polonium-210 and radium-226 in humans and biota of the Arctic. Nature 210:1094-97.

1969. Concentration of the naturally occurring radionuclide's ${ }^{228} \mathrm{Ra},{ }^{210} \mathrm{~Pb}$, and ${ }^{210} \mathrm{Po}$ in aquatic fauna. In Symposium on Radioecology, ed. D.J. Nelson and F.C. Evans, pp. 535-46. Springfield:NTIS CONF-670503.

Holtzman, R.B., P.W. Urnezis, A. Padova, and C.M. Bobula, III. 1979. Contamination of the human food chain by uranium mill tailings piles. Argonne National Laboratory report ANL/ES-69.

Iyengar, M.A.R. and P.M. Markose. 1970. An investigation into the distribution of uranium and daughters in the environment of a uranium ore processing facility. In Radiation and Radioisotopes in Soil Studies and Plant Nutrition, ed. V.A. Kamrak, pp. 143-53. Bombay:Dept. of Atomic Energy.

Jaworowski, Z., L. Kownacka, and S. Wlodek. [1972?] Effect of conventional industry on the pollution of the environment by radium-226. In Radioekologicka Konferencia, pp. 128-40. INIS-mf-887.

Jaworowski, Z., J. Bilkiewicz, and L. Kownacka. 1974. Artificial sources of natural radionuclides in the environment. In National Center for Radiation Protection of the German Democratic Republic report SZS-157, pp. 127-135. 
Jaworowski, Z. and D. Grzybowska. 1977. Natural and radionuclides in industrial and rural soils. Sci. of the Total Env. 7:45-52.

Kamath, P.R., A.A. Khan, S.R. Rao, T.N.V. Pillai, M.L. Borkar, and S. Ganapathy. 1964. Environmental natural radioactivity measurements at Trombay Establishment. In The Natural Radiation Environment, eds. J.A.S. Adams and W.M. Lowder, pp. 957-78. Chicago:Univ. of Chicago Press.

Kamath, P.R., M.A.R. Iyengar, and I.S. Bhat. 1974. The changing radiation environment in India. In Natural Radiation Envrionment II, ed. J.A.S. Adams, W.M. Lowder, and T.F. Gesell, vol. 2, pp. 917-28. Springfield:NTIS CONF-720805.

Kearney, T.H. and R.H. Peebles. 1973. Arizona Flora. Berkeley:Univ. of California Press.

Keefer, D.H. and E.J. Fenyves. 1980 in press. Radiation exposure from radium-226 ingestion. In The Natural Radiation Envrionment III, eds. T.F. Gesell, W.M. Lowder, and J.E. McLaughlin.

Kelley, N.E. 1977. Vegetational stabilization of uranium spoils areas, Grants, New Mexico. Progress report on research supported by the U.S. Department of Energy (Contract No. W7405-ENG36).

1979. Vegetational stabilization of uranium spoil areas, Grants, New Mexico. Los Alamos Scientific Laboratory report LA-7624-T (Ph.D. thesis. Univ. of New Mexico).

Kelley, N.E., L.D. Potter, and M.L. Marple. 1978. Selected trace elements and revegetation of uranium mill tailings piles in the Southwest. In Biomedical and Environmental Research Program of the LASL Health Division, eds. D.F. Petersen and E.M. Sullivan, pp. 92-96. Los Alamos Scientific Laboratory report LA-7254-PR.

Kennington, G.S. and J.E. Doerges. 1978. Report on radiological tissue analyses of selected plants and animals collected from Wyorning uranium districts. Univ. of Wyoming unpublished report prepared for the Wyoming Dept. of Environmental Quality and Game and Fish Dept.

Khademi, B., A. Alemi, and A. Nasseri. 1980 in press. Transfer of radium from soil to plants in the area of high natural radioactivity in Iran (Ramsar). In The Natural Radiation Environment III, eds. T.F. Gesell, W.M. Lowder, and J.E. McLaughlin.

Khalid, R.A., R.P. Gambrell, and W.H. Patrick, Jr. 1977. Sorption and release of mercury by Mississippi River sediment as affected by $\mathrm{pH}$ and redox potential. In Biological Implications of Metals in the Environment, eds. H. Drucker and R.E. Wildung, pp. 297-314. Springfield:NTIS CONF-750929.

Kidd, D.E. and L.D. Potter. 1978. Analysis of metallic cations in the Lake Powell ecosystem and tributaries. National Science Foundation Research Applied to National Needs Lake Powell Research Project Bulletin No. 63.

Kirchmann, R. and G. Berino. 1965. Comportement du ${ }^{292}$ Fin chez Pisum sativum L. Phyton 22:137-39. 
Kirchmann, R., R. Roncucci, and J. Mousny. 1965. Absorption et localisation di 29 Ra chez Pisum sativ'sm L. In Isotopes and Radiation in Soil-Plant Nutrition Studies, pp. 277-300. Vienna:International Atomic Energy Agency.

Kirchmann, R., R. Boulenger, and A. Lafontaine. 1968. Absorption du ${ }^{2}$ Ra par les plantes cultivées. In Proceedings of the First International Congress of Radiation Protection, ed. W.S. Snyder, part 2, pp. 1045-51. London:Pergamon Press.

Kirchmann, R., A. Lafontaine, G. Cantillon, and R. Boulenger. 1973. Etude du cycle biologique parcouru par la radioactivité. Centre d'Etude de l'Energie Nucléaire report BLG-477. 2 vols.

Kirchmann, R., R. Boulenger, J. Colard, and A. Lafontaine. 1977. Evaluation de la dose d l'homme resultant de la présence de radionuclides naturels dans les engrais phosphates d'origine minèrale. In The Proceedings of IVth International Congress of Intermational Radiation Protection Association, ed. G. Bresson, vol. 3, pp. 1037-40. Montreuil:Imprimerie Gauthier-Villars.

Kirchmann, R., J. Darcheville, and G. Koch. 1980 in press. Accumulation of ${ }^{20 a}$ from phosphate fertilizers in cultivated soils and transfer to crops. In The Natural Radiation Environment III, eds. T.F. Gesell, W.M. Lowder, and J.E. McLav:alin.

Klechkovsky, V.M. and I.V. Guliakin. 1958. Behavior of trace amounts of strontium, caesium, ruthenium, and zirconium in soils and plants according to the data of investigations with radioactive isotopes of these elements. In Radioisotopes in Scientific Research, ed. R.C. Extermann, vol. IV, pp. 150-72. New York:Pergamon Press.

Kotsch, J.L. 1977. Radium-226 uptake in selected plants and animals at an uranium mine site. M.S. Thesis. Univ. of Wyoming.

Krebs, A.T. 1962. Radioactivity in man, beast and food. Nature 193:622-24.

Lepape, A. and R. Trannoy. 1934a. Influence du radium sur les rendements culturaux de quelques plantes. Comptes Rendus 199:316-18.

-_ 1934b. Fixation, par les plantes, du radium mis d leur disposition dans le sol. Comptes Rendus 199:803-805.

Lovaas, A.I. and J.B. Hursh. 1968. Radium-226 and lead-210 in human teeth and bones. Health Physics 14:549-55.

Marei, A.N. and A.N. Karmaeva. 1965. Certain health aspects of the radium-226 problems. In USSR Reports on Natural and Artificial Radioactivity in Diet and Man. U.S. Atomic Energy Commission translation AEC-tr-6797.

Marple, M.L., S. Barr, and D.R. Dreesen, 1978. Saltation as a transport mechanism of tailings at an inactive uranium mill site. In Biomedical and Environmental Research Program of the LASL Health Division, eds. D.F. Petersen and E.M. Sullivan, pp. 96-100. Los Alamos Scientific Laboratory report LA-7254-PR.

Marsden, E. and E.N. Greer. 1961. Alpha-activity of wheat and flour. Nature 189:326-27. 
Martin, R.P., P. Newbould, and R.S. Russell. 1958. Discrimination between strontium and calcium in plants and soils. In Radioisotopes in Scientific Research, ed. R.C. Extermann, vol. IV, pp. 173-90. New York:Pergamon Press.

Martin, S.S., W.T. Helm, and W.F. Sigler. 1969. Accumulation of radium-226 in two aquatic ecosystems. In Symposium on Radioecology, eds. D.J. Nelson and F.C. Evans, pp. 307-18. Springfield:NTIS CONF-670503.

Maslov, V.I., B.I. Gruzdev, and K.I. Maslova. 1969. The role of muriform rodents in the biogenic migration of uranium, radium and thorium under different radioecological conditions. In Actes du Symposium International de Radioecologie, vol. 2, pp. 923-59. Cadarache:Centre d'Etudes Nucléaires.

Mayneord, W.V. and C.R. Hill, 1959. Spectroscopic identification of alpha-emitting nuclides in biological material. Nature 184:667-69.

Mayneord, W.V., Turner, R.C. and J.M. Radley. 1960. Alpha activity of certain botanical materials. Nature 187:208-11.

Menzel, R.G. 1954. Competitive uptake by plants of potassium, rubidium, cesium, and calcium, strontium, barium from soils. Soil Sci. 77:419-25.

1965. Soil-plant relationships of radioactive elements. Health Physics 11:1325-32.

1968. Uranium, radium, and thorium content in phosphate rocks and their possible radiation hazard. J. Agr. Food Chem. 16:231-34.

Mercer, E.R., W.A. Mitchell, and K.A. Smith. 1962. Absorption by plants of naturally occurring radioactive materials. In Annual Report 1961-62, pp. 82-83. British Agricultural Research Council Radiobiological Laboratory report ARCRL-8.

Mericle, L.W. and R.P. Mericle. 1965. Reassessing the biological role of background terrestrial radiation as a constituent of the natural environment. Health Physics11:1607-20.

Merritt, R.C. 1971. The Extractive Metallurgy of Uranium. Boulder:Johnson Publ. Co.

Miller, M.L., J.J. Fix, and P.E. Bramson. 1977. Radiochemical analyses of soil and vegetation samples taken from the Hanford environs, 1971-1976. Battelle Pacific Northwest Laboratories BNWL-2249.

1980 in press. Log-normal analysis of naturally occurring radionuclides in soil and vegetation of the Hanford area. In The Natural Radiation Environment III, ed. T.F. Gesell, W.M. Lowder, and J.E. McLaughlin.

Mistry, K.B. 1963. Agriculture Research Council Radiobiological Laboratory report ARCRL10. London:H.M. Stationery Office.

Mistry, K.B., A.R. Gopal-Ayengar, and K.G. Bharathan. 1965. On the radioactivity of plants from the high radiation areas of the Kerala coast and adjoining regions. II. Studies on the uptake of alpha and gamma emitters. Health Physics 11:1459-70. 
Moffett, D. and M. Tellier. 1977. Uptake of radioisotopes by vegetation growing on uranium tailings. Car. J. Soil. Sci. 56:417-24.

-_1978. Radiological investigations of an abandoned uranium tailings area. J. Environ. Qual. 7:310-14.

Moffett, D., G. Zahary, M.C. Campbell, and J.C. Ingles. 1978. Canmet's environmental and process research on uranium. Paper read at Seminar on Management, Stabilisation, and Environmental Impact of Uranium Mill Tailings, 24-28 July 1978, at Albuquerque, New Mexico.

Moore, H.E. and S.E. Poet. 1976. Background levels of ${ }^{2} \mathrm{Ra}$ in the lower troposphere. Atmos. Env. 10:381-83.

Murray, D.R. 1978. Influence of uranium mill tailings on tree growth at Elliot Lake. C.I.M. Bulletin 71(800):79-81.

Murray, D.R. and D. Moffett. 1977. Vegetating the uranium mine tailings at Elliot Lake, Ontario. J. Soil Water Cons. 32:171-74.

Muth, H., B. Rajewsky, H.-J. Hantke, and K. Aurand. 1960. The normal radium content and the ${ }^{200 \mathrm{Ra}} / \mathrm{Ca}$ ratio of various foods, drinking water, and different organs and tissues of the human body. Health Physics 2:239-45.

Nathwani, J.S. and C.R. Phillips. 1978. Rates of leaching of radium from contaminated soils: an experimental investigation of radium-bearing soils from Port Hope, Ontario. Water, Air, and Soil Poll. 9:453-65.

National Research Council. 1976. Selenium: Medical and Biological Effects of Environmental Pollutants. Washington:National Academy of Sciences.

Nizhnikov, A.I., A.P. Yermolayeva-Maliovskaya, M.S. Itabullin, B.P. Lisachenko, B. Ya. Litver, P.V. Ramzayev, L.A. Teplykh, and M.N. Troitskaya. 1973. Lead-210, polonium-210, radium-226, thorium-228, and plutonium-239 in the lichen-deer-man chain in the far northern regions of the USSR. In USSR Reports on Natural and Fallout Radioactivity, pp. 5764. New York:U.S. Atomic Energy Commission Health and Safety Lab. report AEC-tr-7570.

Oakes, T.W., K.E. Shank, and C.E. Easterly. 1976. Natural and man-made radionuclide concentrations in Tennessee soils. U.S. Energy Research and Development Administration report CONF-761031-3.

Osburn, W.S. 1965. Primordial radionuclides: Their distribution, movement, and possible effect within terrestrial ecosystems. Health Physics 11:1275-95.

Ovchenkov, V. Ya. 1972. Radium migration from sites of its concentration under natural conditions. In Radioekologicheskie Issledovaniya $v$ Prirodnykh Biogeotsenozakh, ed. I.N. Verkhovskaya, pp. 147-53. Moscow:Izdatel'stvo Nauka.

Ovchenkov, V. Ya. and D.M. Rubstov. 1972. The content of radioactive isotopes of the uranium and thorium series in soils. In Radioekologicheskie Issledovaniya $v$ Prirodnykh Biogeotsenozakh, ed. I.N. Verkhovskaya, pp. 86-93. Moscow:Izdatel'stvo Nauka. 
Packard, Charlcs. 1918. Difference in the action of radium on green plants in the presence and absence of light. J. Gen. Phys. 1:37-38.

Palamarchuk, A.S. 1963. Stimulation of the growth of roots of the Chenopodiaceae, Cruciferae, and Umbelliferae in peat and mineral soils by gamma-rays of radium and cobalt and by $x$-rays. French Commissariat á l'Energie Atomique translation CEA-tr-R-1678.

Pallister, E.T. and J.H. Green. 1964. Radium-226 content of natural waters and coal in New South Wales. Nature 201:813-14.

Parsont, M.A. 1967. The distribution of $R a$ in an aquatic environment. Ph.D. Thesis. Colorado State Univ.

Pearson, J.E. and G.E. Jones. 1966. Soil concentratiuns of "emanating radium-226" and the emanation of radon-222 from soils and plants. Tellus 18:655-61.

Pendleton, R.C., R.D. Lloyd, C.W. Mays, D.R. Atherton, and N.V. Chamberlain. 1964. Radium contamination at the Jordan River Delta of the Great Salt Lake. J. Water Poll. Cont. Fed. 36:925-27.

Penna-Franca, E. and O. Gomes de Freitas. 1963. Radioactiviy of biological materials from Brazilian areas rich in thorium compounds. Nature 197:1062-63.

Penna-Franca, E., J.C. Almeida, J. Becker, M. Emmerich, F.X. Roser, G. Kegel, L. Hainsberger, T.L. Cullen, H. Petrow, R.T. Drew, and M. Eisenbud. 1965a. Status of investigations in the Brazilian areas of high natural radioactivity. Health Physics 11:699-712.

Penna-Franca, E., C. Costa-Ribeiro, M. Teitakowski, H. Londres, P.L. Santos, and H.A. Albuquerque. 1965b. Survey of radioactive content of food grown on Brazilian areas of high natural radioactivity. Health Physics 11:1471-84.

Penna-Franca, E., M. Fiszman, N. Lobão, C. Costa-Ribeiro, H. Trindade, P.L. dos Santos, and D. Batista. 1968. Radioactivity of Brazil nuts. Health Physics 14:95-99.

Penna-Franca, E., M. Fiszman, N. Lobão, H. Trindade, C. Costa-Ribeiro, and P.L. Santos. 1970. Radioactivity in the diet in high background areas of Brazil. Health Physics 19:657-62.

Perkins, B.L. 1979. An overview of the New Mexico uranium industry. New Mexico Energy and Minerals Department report.

Pertsov, L.A. 1967. The natural radioactivity of the biosphere. U.S. Atomic Energy Commission translation AEC-tr-6714m.

Pietrzak-Fils, Z. 1972. Radium-226 in Polish diet and foodstuffs. Nukleonika 17:227-31.

Powers, R.P., N.E. Turnage, and L.G. Kanipe. 1980 in press. The determination of radium226 in environmental samples. In The Natural Radiation Environment III, eds. T.F. Gesell, W.M. Lowder, and J.E. McLaughlin.

Purtymun, W.D., C.L. Wienke, and D.R. Dreesen. 1977. Ger'ogy and hydrology in the vicinity of the inactive uranium mill tailings pile, Ambrosia Lake, New Mexico. Los Alamos 
Scientific Laboratory report LA-6839-MS.

Pusey, W.A. 1911. The biological effects of racium. Science 33:1001-1005.

Redfield, A.C. and E.M. Bright. 1922. The effects of radium rays on metabolism and growth in seeds. J. Gen. Phys. 4:297-301.

Robinson, W.O. and G. Edgington. 1945. Minor elements in some accumulator plants. Soil Sci. 60:15-28.

Roessler, C.E., R. Kautz, W.E. Bloch, Jr., and J.A. Wethington, Jr. 1980 in press. The effect of mining and land reclamation on the radiological characteristics of the terrestrial environment of Florida's phosphate regions. In The Natural Radiation Environment III, eds. T.F. Gesell, W.M. Lowder, and J.E. McLaughlin.

Romney, E.M., G.V. Alexander, W.A. Rhoads, and K.H. Larson. 1959. Influence of calcium on plant uptake of Sr-90 and stable strontium. Soil Sci. 87:160-65.

Romney, E.M., R.G. Lindberg, H.A. Hawthorne, B.G. Bystrom, and K.H. Larson. 1963. Contamination of plant foliage with radioactive fallout. Ecology 44:343-49.

Ross, William H. 1914. The use of radioactive substances as fertilizers. U.S. Dept. of Agriculture Bulletin No. 149.

Rubtsov, D.M. 1972. Distribution of uranium and radium in the podzolic mountain soils of thin forests. In Radioekologicheskie Issledovaniya $v$ Prirodnykh Biogeotsenozakh, ed. I.N. Verkhovskaya, pp. 42-53. Moscow:Izdatel'stvo Nauka.

Rusanova, G.V. 1962. Study of leaching and migration of radium in soils. Pochvovedenie (9):962-64.

280 .

1964. Behavior of radium and calcium in the soil-plant system. Pochvovedenie (3):275-

- 1972 . Radium content of soils in regions with a high radiation background and the ef. fect of fertilizers on radium mobility. In Radioekologicheskie Issledovaniya $v$ Prirodnykh Biogeotsenozakh, ed. I.N. Verkhovskaya, pp. 22-33. Moscow:Izdatel'stvo Nauka.

Russell, E.J. 1915. The effect of radium on the growth of plants. Nature 96:147-43.

- 1932. Soil Conditions and Plant Growth. New York:Longmans, Green, and Co.

Russell, I.J. 1971. Radial distribution of fallout nuclides and radium isotopes in a 107 year oak trunk. U.S. Atomic Energy Commission NYO-3756-7.

Russell, R.S. 1963. The extent and consequences of the uptake by plants of radioactive nuclides. Ann. Rev. of Plant Phys. 14:271-94.

Sanderson, C.G. 1969. Determination of radium-226 and thorium-228 in food, soil, and biological ash by multidimensional coincident gamma-ray spectrometry. Health Physics 16:747-53. 
Schiager, K. 1977. Radwaste radium-radon risk. In Proceeding: $A$ Workshop on Policy and Technical Isaces Pertinent to the Development of Environmental Protection Criteria for Radioactive Wastes, pp. 2-45 to 81. Las Vegas:U.S. Environmental Protection Agency ORP/CSD-77-2.

Schmidtke, N.W., D. Averill, D.N. Bryant, P. Wilkinson, and J.W. Schmidt. 1978. Removal of ${ }^{m} \mathrm{Ra}$ from tailings pond effluents and stabilization of uranium mine tailings-Bench and pilot scale studies. Paper read at Seminar on Management, Stabilisation, and Environmental Impact of Uranium Mill Tailings, 24-28 July 1978, at Albuquerque, New Mexico.

Schwendiman, L.C., G.A. Sehmel, T.W. Horst, C.W. Thomas, and R.W. Perkins. 1979. A field and modeling study of windblown particles from a uranium mill tailings pile. Pacific Northwest Laboratory report NUREG/CR-0629.

Shearer, S.D., Jr. 1962. The leachability of radium-226 from uranium mill wastes solids and river sediments. Ph.D. Thesis. Univ. of Wisconsin.

Shearer, S.D., Jr. and G. F. Lee. 1964. Leachability of radium-226 from uranium mill solids and river sediments. Health Physics 10:217-27.

Silberstein, H.E. 1950. Historical background. In Biological Studies with Polonium, Radium, and Plutonium, ed. R.M. Fink, pp. 157-75. New York:McGraw-Hill.

Smith, K.A. 1967. The uptake and translocation by plants of the alkaline earth elements calcium, strontium, barium and radium. Ph.D. Thesis. Univ. of Reading.

1971a. The comparative uptake and translocation by plants of calcium, strontium, barium, and radium. I. Bertholletia excelsea (Brazil nut tree). Plant and Soil 34:369-79.

- 1971b. The comparative uptake and translocation by plants of calcium, strontium, barium, and radium. II. Triticum vulgare (wheat). Plant and Soil 34:643-51.

Snelling, R.N. 1970. Environmental survey of uranium mill tailings pile, Monument Valley, Arizona. Radiol. Health Data and Reports 11:511-17.

- 1971. Environmental survey of uranium mill tailings pile, Mexican Hat, Utah. Radiol. Health Data and Reports 12:17-27.

Sokal, R.R. and. F.J. Rohlf, 1969. Biometry. San Francisco:W.H. Freeman and Co.

Spiers, F.W. 1956. Radioactivity in man and his environment. Brit. J. Radiol. 29:409-17.

Squire, H.M. 1966. Long-term studies of strontium-90 in soils and pastures. Rad. Bot. 6:4967.

Stoklasa, J. 1922. Uber die Einwirkung des Selens auf den Bau- und Betriebs-stoffwechsel der Pflanze bei Anwesenheit der Radioaktivität der Luft und des Bodens. Biochem. Z. 130:604-43.

Titaeva, N.A. 1957. On the character of radium and uranium bond in peat. Geochem. Intl. 4:1168-74. 
Titaeva, N.A., R.M. Aleksakhin, V.I. Maslov, and A.I. Taskaev. 1980 in press. Migration of heavy natural radionuclides in a humid climatic zone. In The Natural Radiation Environment III, eds. T.F. Geseli, W.M. Lowder, and J.E. McLaughlin.

Tsivoglou, E.C. 1964. Environmental monitoring in the vicinity of uranium mills. In Radiological Health and Safety in Mining and Milling of Nuclear Materials, vol. II, pp. 23145. Vienna:International Atomic Energy Agency.

Tsivoglou, E.C., M. Stein, and W.W. Towne. 1960. Control of radioactive pollution of the Animas River. J. Water Poll. Cont. Fed. 32:262-87.

Tsivoglou, E.C., S.D. Shearer, Jr., J.D. Jones, and D.A. Clark. 1960. Estimating human radiation exposure on the Animas River. J. Amer. Water Works Assn. 52:1071-90.

Tsivoglcu, E.C. and R.L. O'Connell. 1962. Waste guide for the uranium milling industry. U.S. Public Health Service R.A. Taft San. Engrg. Center report TSEC-TR-W62-12.

- 1964. Nature, volume and activity of uranium mill wastes. In Radiological Health and Safety in Mining and Milling of Nuclear Materials, vol. II, pp. 101-22. Vienna:International Atomic Energy Agency.

Tso, T.C., N.A. Hallden, and L.T. Alexander. 1964. Radium-226 and polonium-210 in leaf tobacco and tobacco soil. Science 146:1043-45.

Tukey, H.B., S.H. Wittwer, F.G. Teubner, and W.G. Long. 1956. Utilization of radioactive isotopes in resolving the effectiveness of foliar absorption of plant nutrients. In Proc. Int. Conf. Peaceful Uses of Atomic Energy, vol. 12, pp 138-143. New York:United Nations.

Tukey, H.B., S.H. Wittwer, and H.B. Tukey, Jr. 1958. Leaching of nutrients from plant foliage as determined by radio-isotopes. In Radioisotopes in Scientific Research, ed. R.C. Extermann, vol. IV, pp. 304-22. New York:Pergamon Press.

Turner, R.C., J.M. Radley, and W.V. Mayneord. 1958a. Alpha-ray activities of humans and their environment. Nature 181:518-21.

$-1958 \mathrm{~b}$. The naturally occurring $\alpha$-ray activity of foods. Health Physics 1:268-275.

_-1961. Naturally occurring alpha-activity of drinking waters. Nature 189:348-52.

U.S. Atorisic Energy Commission. 1963. A report of the Monticello mill tailing erosion contral project, Monticello, Utah. Report No. RMO-3005.

1966. Supplement to the report of the Monticello mill tailing erosion control project. Report No. RMO-3005.

_ 1974. Summary report Phase I study of inactive uranium mill sites and tailings piles.

Van der Borght, O. 1963. Accumulation of radium-226 by the freshwater gastropod Lymnaea stagnalis L. Nature 197:612-13.

Vassilaki, M., L. Salmon, and J.A.B. Gibson. 1966. Measurement of radioactivity in soil. 
Geochim. Cosmochim. Acta 30: 601-606.

Vavilov, P.P., I.N. Verkhovskaya, R.P. Kodaneva, and O.N. Popova. 1963. Growth and development of Vicia faba $\mathrm{L}$. under conditions of an increased soil content of uranium and radium. Radiobiologiya 3:186-96.

Vavilov, P.P., O.N. Popova, and R.P. Kodaneva. 1964. On the behaviour of radium in plants. Doklady Akad. Nauk SSSR 157:992-94.

Vavilov, P.P., I.N. Verkhovskaya, O.N. Popova, and R.P. Kodaneva. 1972a. Conditions of radium accumulation by plants from the soil. In Radioekologicheskie Issledovaniya $v$ Prirodnykh Biogeotsenozakh, ed. I.N. Verkhovskaya, pp. 95-103. Moscow:Izdatel'stvo Nauka.

Vavilov, P.P., N.S. Eyges, O.N. Popova, and R.P. Kodaneva. 1972b. Investigations of meiosis in irradiated plants and in plants grown in soils with a high uranium and radium content. In Radioekologicheskie Issledovaniya v Prirodnykh Biogeotsenozakh, ed. I.N. Verkhovskaya, pp. 103-12. Moscow:Izdatel'stvo Nauka.

Verkhovskaya, I.N., P.P. Vavilov, and V.I. Maslov. 1967. The migration of natural radioactive elements under natural conditions and their distribution according to biotic and abiotic environmental components. In Radioec F.P. Hungate, pp. 313-28. New York:Pergamon Press.

Verkhovskaya, I.N., B.I. Gruzdev, V.I. Maslov, K.I. Maslova, V.S. Nikiforov, V.J. Ovchenkov, O.N. Popova, D.M. Rubtsov, and P.P. Vavilov. 1969. The content and translocation of natural radioactive elements in the system "soil-plants-animals" under natural and experimental conditions. In Actes du Symposium Inter'zational de Radioecologie, vol. 2, pp. 781-832. Cadarache:Centre d'Etudes Nucléaires.

Verkhovskaya, I.N., P.P. Vavilov, and V.I. Maslov. 1972. Distribution and redistribution of uranium, radium, and thorium in naturai biogeocenoses. In Radioekologicheskie Issledovaniya v Prirodnyky Biogeotsenozakh, ed. I.N. Verkhovskaya, pp. 243-56, Moscow:Izdatel'stvo Nauka (RFP-trans-162).

Vermadsky, W. 1929. On the concentration of radium by living organisms. Doklady Akad. Nauk SSSR Ser. A:33-34.

-1930. Sur la concentration du radium par les plantes. Doklady Akad. Nauk SSSR Ser. A:539-42.

Voelker, A.H. 1978. A design for planning the cleanup of formerly used radium-contaminated sites. Oak Ridge National Laboratory report ORNL/TM-6298.

Waller, S.S. and J.D. Dodd, 1976. Andropogon scoparius uptake of calcium-45 and production from two contrasting soil types. In Radioecology and Energy Resources, ed. C.E. Cushing, Jr., pp. 325-30. Stroudsburg:Dowden, Hutchinson, and Ross.

Watson, G.M. 1975. Rum Jungle environmental studies. Australian Atomic Energy Commission Research Establishment report AAEC/E-366.

Wewerka, E.M., J.M. Williams, N.E. Vanderborgh, A.W. Harmon, P. Wagner, P.L. Wanek, 
and J.D. Olsen. 1978. Trace element characterization of coal wastes-Second annual progress report. U.S. Department of Energy report LA-7360-PR.

Whicker, F.W. 1978. Biological interactions and reclamation of uranium mill tailings. In Uranium Mill Tailings Management, vol. 1, pp. 141-53. Fort Collins:Colorado State Univ.

Whitehead, N.E., R.R. Brooks, and G.E. Coote. 1971. Gamma radiation of some plants and soils from a uraniferous area in New Zealand. New Zealand J. Sci. 14:66-76.

Winsor, T.F. and. D.W. Stahlecker. 1974. An examination of radionuclide effluent upon soil and biota at the Shirley Basin uranium mine. Colorado State University unpublished report prepared for Utah International, Inc.

Winsor, T.F. and F.W. Whicker. 1975. U-238, Ra-226, and Pb-210 in soil and vegetation at the Lucky Mc uranium mine and mill. Colorado State University unpublished report prepared for Utah International, Inc.

Wlodek, S., D. Grzybowska, and M. Bysiek. 1970. The effect of human activity upon migration of radium-226 in the environment. Nukleonika 15:675-81. 


\section{APPENDIX}

A brief history of the study of biological effects of radium shows interest immediately after its discovery in the effect of radium rays (usually from radium bromide sources) on plant growth. In a pioneer paper, Becquerel (1901) demonstrated the partial or complete inhibition of germination of seeds with sufficient exposures. Retardation of the subsequent growth of seedlings was also documented (Dixon 1903). The possibility of a phototactic response was often considered but not usually observed. At low doses, some acceleration of growth and germination was observed also (Guilleminot 1907), but many of these early papers (of which there were more than 100 between 1901 and 1908) reported inhibitory effects. Many studies of seed germination and physiological processes with different species under different conditions were undertaken by Gager (1908a). The presence of stimulatory effects was confirmed but minimum and maximum points of exposure were not established (Gager 1908b). More investigations continued to reveal radium's influence on cellular processes and growth (Hẻbert and Kling 1909; Pusey 1911). Due to the existence of stimulatory effects at low doses, Ross (1914) undertook a study of "radioactive manures" which were waste products from the processing of uranium and radium ores. However, the natural quantity of radium in one acrefoot of soil was seen to be 100 times that of a normal manure application, so little benefit was ascribed to such manures in farming. Russell (1915) summarized many of the earlier results on the effects of radium on plant growth such as the stronger response in roots compared to shoots and the forcing of lilacs into bloom; he concluded that radium could stimulate certain cellular activities but that overall growth was not affected.

Investigations of the effects of "radium emanation" (radon-222) were often included in these early studies. Agulhon and Robert (1915) observed activation of growth by radon and suggested that the normal levels of soil radioactivity could play a role in plant life. Similar work was also performed with lower plants where greater sensitivity was evident in darkness as compared with light (Packard 1918). Some influence of radium in reducing selenite toxicity was also reported (Stoklasa 1922, cited by National Research Council 1976). Other investigators observed increased production of carbon dioxide with decreased seed germination (Redfield and Bright 1922) and chromosomal mutants in buds exposed to radium bromide (Gager and Blakeslee 1927).

Later investigations began to focus on the uptake and subsequent content of radium in plants. First Lemna and selected land plants were studied in the Soviet Union; contents of approximately $0.01 \mathrm{pCi} / \mathrm{g}$ in water, $0.2 \mathrm{pCi} / \mathrm{g}$ in Lemna, and $0.03 \mathrm{pCi} / \mathrm{g}$ in land plants were reported (Vernadsky 1929; Brunovskij and Kunaseva 1930). The measurements of radium and uranium in plants from mine spoils were first begun at that time (Vernadsky 1930) but few results are available. Also at this time, the radium contents of different types of rocks were evaluated; they ranged from 1 to $3 \mathrm{pCi} / \mathrm{g}$ (Russell 1932). A review of papers between 1901 and 1932 (Gager 1936) described intensive investigations on various aspects of seed germination, radioactive fertilizers, and genetic effects.

The first systematic study of the relation between radium uptake and biomass in several species of plants grown in different soils spiked with radium was reported by Lepape and Trannoy (1934a, 1934b). The soils contained 0.5 to $1.0 \mathrm{pCi} / \mathrm{g}$ radium and the spiked levels were 10,100 , and 1000 times the normal level. Only at the 1000 times activity of normal suil was there a decrease in biomass. The activity of radium in plants grown in normal soil was 0.03 to $0.3 \mathrm{pCi} / \mathrm{g}$; the activity of plants grown in 100 times normal soil was 0.3 to $20 \mathrm{pCi} / \mathrm{g}$ with 
different soils and species accounting for the wide variation. For example, a silt soil had higher radium activity compared to a sandy soil and uptake was greater from the silt soil. For corn grown in a clay soil, a large difference between the radium content of different parts was observed for all treatments; the activity of leaves was more than three times that of stems and the activity of stems was more than 10 times that of the fruits.

A later study used water cultures of peas (Drobkov 1937). Increases of 150 to $300 \%$ in the biomass of stalks, roots, and seeds were observed in solutions of $10^{-11}, 10^{-10}, 10^{-1}, 10^{-1} \mathrm{~g}$ of radium in $6 \ell$ compared to controls. Radium contents in stalks varied by two orders of magnitude (from 0.05 to $5.0 \mathrm{pCi} / \mathrm{g}$ ) while corresponding values for the roots varied from 0.1 to $100 \mathrm{pCi} / \mathrm{g}$ for these four treatments. The radium activities of the roots were 40 to 500 times those of the stalks. In opposition to these results, Baranov (1939) found little variation in the radium activity of pea roots over a 1000 -fold difference in the activity of nutrient solutions. $\mathrm{He}$ did observe a tenfold variation in shoot concentration and a ratio of root activity to shoot activity of 2 to 20. For lettuce, he reported less radium uptake than pea; however, barley and flax both showed considerable uptake of radium and the activity of the roots was much higher than that of the shoots (10-500 times). An increase in root growth and rubber content of koksaghyz was described by Drobkov (1941) for soils containing 0.1 to $1.0 \mathrm{pCi} / \mathrm{g}$. Drobkov (1949) later described various effects of radium on plant growth. At about $1000 \mathrm{pCi} / \mathrm{g}$, rose buds withered, but at $1 \mathrm{pCi} / \mathrm{g}$, blooming was accelerated. Radium in fertilizer could increase the sugar content of sugar beets by $50 \%$. However, the use of dolomitic limestone with radium activity of $6000 \mathrm{pCi} / \mathrm{g}$ was reported as having no effect on yields of several different crop species (Alexander 1950). Thus, variable results in the effects of radium on plant yield and on the uptake of radium by plants were reported depending on the concentrations of radium, the micronutrients present in the medium as contaminants, the conditions of the experiments, and the species studied.

Soon after the Second World War, a search for uranium deposits led to the use of biological prospecting for uranium ores. Intensive work in this area was conducted on the Colorado Plateau where vanadium, selenium, and molybdenum concentrations in addition to those of uranium were used and where possible anomalous growth due to radium were considered (Cannon 1952). Some surveys were undertaken near Bluewater, N.M. (Cannon 1953) but artificial contamination within several kilometers of a uranium mill was a complicating factor (Cannon 1954). Similar research was conducted in the Soviet Union and led to the mapping of natural radioactive elements over wide areas (Aleksakhin and Vasil'yevskaya 1960). Recently, biogeochemical prospecting has been used in New Zealand; radium activity accounted for 5 to $14 \%$ of the total alpha activity (Whitehead, Brooks, and Coote 1971).

Many investigations have centered around the evaluation of the natural radiation dose to man. The problem of the normal radium content of the human body was studied by measuring both radium-226 content and the radium:calcium ratio of autopsy material; radium was found to behave like a bone-seeker, because of its chemical similarity to calcium, but there existed a strong discrimination against it as compared to calcium due to its larger ion size (Muth et al. 1960). Studies of dietary intake of radium produced many results on the radium content of drinking waters, foods, and soils. For cereals and potatoes, Spiers (1956) reported 0.003 $\mathrm{pCi} / \mathrm{g}$ and $0.01 \mathrm{pCi} / \mathrm{g}$ of radium-226, respectively. Other results were reported for alpha activity; for example, activities of many fruits and vegetables were found to be less than 0.01 $\mathrm{pCi} / \mathrm{g}$, with $57 \%$ of that activity being due to radium-226 (Turner, Radley, and Mayneord 1958a). Brazil nuts from Brazil, Malaya, and British Guiana all had very high, naturally occurring, alpha activities of which $18 \%$ was due to radium-226 (Turner, Radley, and Mayneord $1958 \mathrm{~b})$. The alpha activity of grass in Great Britain was 1 to $170 \mathrm{pCi} / \mathrm{g}$, with $9 \%$ of that being from polonium-210 (Mayneord ard Hill 1959). Little correlation was found between activity, either total alpha or radium, in soji and grass ash (Mayneord, Turner, and Radley 1960). Hill 
(1960) verified the important contribution of natural fallout of lead-210 and polonium-210 to the alpha activity of grasses. Later studies focused on the radium activity in foods and its relationship with the calcium concentration. Carrots, cabbages, apples, and potatoes were reported to have 0.001 to $0.006 \mathrm{pCi} / \mathrm{g}$ radium and 0.01 to $0.09 \%$ calcium (Muth et al. 1960); as the radium activity increased, the ratio of that activity to the calcium content also increased. Similar studies of the radium and/or alpha activity of waters (Turner, Radley, and Mayneord 1961) and wheat (Marsden and Greer 1961) were reported. Other radium isotopes were also measured, such as radium-224 (Gopal-Ayengar and Mistry 1962). Solid food (as opposed to milk) was identified as a major contributor to the intake of radioactivity and the radium burden thus derived can be carried for a long time (Krebs 1961). Widely varying levels were reported (Russell 1963) but the radium-226 activity in food was shown to be an important component of the natural radiation dose to man.

Other investigations related the radium-226 content in bone to diet (Hallden, Fisenne, and Harley 1963). Comparisons between the radium-226 content in diets in different locations were also made. For instance, in Puerto Rico, the radium activity of plant foods was from 0.3 to $2.7 \mathrm{pCi} / \mathrm{g}$ (Hallden and Harley 1964). Regions with high natural radiation, such as the Morro de Ferro in Brazil, were compared with background areas like New York; foods in Brazil contained about three times as much radium as those in New York (Eisenbud et al. 1964). Bread was reported to be a major contributor of radium to dietary intake (Marei and Karmaeva 1965). Measurements of the radium content of tobaccos and the soils in which they were grown were also made (Tso, Hallden, and Alexander 1964). The alpha activity due to radium-226 was also determined for cigars, cigarettes, tea, and coffee (Green and Pallister 1965).

Some studies focused on natural radium activity in soil and activity of crops grown in that soil. Surface soils in Britain ranged from 0.5 to $2.1 \mathrm{pCi} / \mathrm{g}$, with a mean of $1.3 \mathrm{pCi} / \mathrm{g}$ (Vassilaki, Salmon and Gibson 1966). Sanderson (1969) reported normal soil activities of 1.0 to $1.5 \mathrm{pCi} / \mathrm{g}$ (mean $1.2 \mathrm{pCi} / \mathrm{g}$ ) and food activities of $0.03 \mathrm{pCi} / \mathrm{g}$. For a coarse sandy loam in California, Hansen (1970) reported 1.0 to $2.3 \mathrm{pCi} / \mathrm{g}$ (mean $1.8 \mathrm{pCi} / \mathrm{g}$ ). In Tennessee soils, the radium content varied from 0.8 to $1.6 \mathrm{pCi} / \mathrm{g}$ (Oakes, Shank, and Easterly 1976). In a white oak tree, Russell (1971) found $0.1 \mathrm{pCi} / \mathrm{g}$ dry weight. For soils and plants, Brooks (1972) reported average activities of $0.8 \mathrm{pCi} / \mathrm{g}$ and $0.004 \mathrm{pCi} / \mathrm{g}$ dry weight, respectively. Fisenne (1967) found background soil levels of 0.7 to $1.4 \mathrm{pCi} / \mathrm{g}$ and plant radium contents of $0.3 \mathrm{pCi} / \mathrm{g}$. For edible plants, the activities were less than $0.001 \mathrm{pCi} / \mathrm{g}$ while the soil activity was $0.7 \pm 0.1 \mathrm{pCi} / \mathrm{g}$ (de Bortoli and Gaglione 1972). In a similar study, lettuce and cabbage had 0.01 to $0.03 \mathrm{pCi} / \mathrm{g}$ and soil had 0.4 pCi/g (Jaworowski, Kownacka, and Wlodek 1972). Four soils of different texture in New Zealand had activities of 0.4 to $0.9 \mathrm{pCi} / \mathrm{g}$ (Baltakmens 1974). Thus, the results of diverse studies of natural radium levels in soils and foods showed normal soil activities of 0.5 to 1.5 $\mathrm{pCi} / \mathrm{g}$ in most locations and food activities less than $0.01 \mathrm{pCi} / \mathrm{g}$ dry weight. Hollins (1977) used many of these results to calculate body burdens from radium in vegetables; the permissible soil activity of radium depended on the duration of garden use, and for fifty years use, the maximum permissible soil activity was $220 \mathrm{pCi} / \mathrm{g}$.

The problems of plant uptake of radium from soils wiere also addressed. Radium was not concentrated in dry plant material relative to soil and radium, like barium, was shown to be more strongly adsorbed in soils than the common alkaline earth cations (Menzel 1965). The normal level of radium activity in soil was reported as $0.8 \mathrm{pCi} / \mathrm{g}$ and over one-half of this radium was probably fixed in the soil (Osburn 1965). Radium was retained more than strontium by soil surfaces in experiments with leaching by $0.01 \mathrm{M}$ calcium chloride solutions, suggesting the availability of radium to plants is lower than that of strontium and calcium (Mistry 1963, cited by Osburn 1965). In an area of high uranium content, radiation effects in the radiosensitive Tradescantia were documented and were found to interact with en- 
vironmental factors (Mericle and Mericle 1965). Natural levels of radium-226 were also measured in the Arctic, where vegetation (lichens and horsetails) contained $0.2 \mathrm{pCi} / \mathrm{g}$ dry weight (Holtzman 1966). In a review of many results, Bowen (1966) concluded that natural radium activity was $0.8 \mathrm{pCi} / \mathrm{g}$ for soil and $0.001 \mathrm{pCi} / \mathrm{g}$ for land plants.

A large amount of diverse research was conducted in the Soviet Union (Francis, Talmage, and $\mathrm{McMullin}$ 1975). The optimal doses from the gamma rays of radium were studied for many agricultural species (Palamarchuk 1963). Anomalies were observed in plants grown in soil with a radium activity of $160 \mathrm{pCi} / \mathrm{g}$; experimental plants grown in soil containing 1000 $\mathrm{pCi} / \mathrm{g}$ had lower stem height (by 0 to $60 \%$ ) and lower crude weight (by 35 to $50 \%$ ) for both roots and whole plants (Vavilov et al. 1963). Many reports were made on the radium activity of different soil types and its distribution in soil horizons; fluctuations of two orders of magnitude were reported for different soils (Baranov et al. 1963). Corresponding studies on plant uptake of radium were also conducted. The general conclusion was an acropetal distribution of radium in leaves (Vavilov, Popova, and Kodaneva 1964). A negative relationship between both mobile radium in the soil and radium uptake by plants and calcium content in the soil was found (Rusanova 1964). The effect of vestation on radioactive contamination of soil by altering water movement was also considered (Gedeonov, Rosyanov, and Vinogradova 1967). In general, dicots had higher radium activity $(0.03 \mathrm{pCi} / \mathrm{g})$ than monocots $(0.01 \mathrm{pCi} / \mathrm{g})$ (Pertsov 1967). Later, more detailed studies of different species, tissues, and soil parameters were undertaken. For trees, the order of decreasing radium activity in plant ash was bark $>$ wood $>$ leaves, and in vegetables, the order was roots $>$ leaves $>$ stems; radium activity in soils was observed to increase with organic matter content and with absorbed bases, but exchangeable radium decreased as the mobility of calcium and magnesium increased (Verkhovskaya, Vavilov, and Maslov 1967). In the Caucasus region, the highest radium activity was found in soils of bitumen-enriched or oil-producing areas (Brendakov, Iokhel'son, ana Churkin 1967). In the Volga region, an area with natural radioactivity ten times that of another area, had food plants with activities 50 to $200 \%$ higher (Belova and Lun'kina 1967). A survey of the radium activity of soils from the European part of the USSR showed four orders of magnitude variation; peats had lower activities than the mineral soils, which normally contained 0.7 to $1.0 \mathrm{pCi} / \mathrm{g}$ (Baranov and Morozova 1969). Selective radium absorption was observed for several species on some of these soils; plants grown in spiked soils (100-1000 $\mathrm{pCi} / \mathrm{g}$ ) contained from 1 to $13 \mathrm{pCi} / \mathrm{g}$ dry weight (mean $5 \mathrm{pCi} / \mathrm{g}$ ) with the highest content in early growth (Verkhovskaya et al. 1969). Other investigators studied radium and uranium sites in the northern taiga where a sand and gravel cover from 20 to $50 \mathrm{~cm}$ thick was placed over the soil which contained $500 \mathrm{pCi} / \mathrm{g}$ radium; the radium activity of several plant species over five years was reported (Maslov, Gruzdev, and Maslova 1969). Aleksakhin (1971) summarized many of these results on the migration of radionuclides, particularly radium in soil.

Continued studies of the behavior of radium in the plant-soil system revealed the association of radium with litter in ecosystems and its greater bioavailability compared to uranium and thorium (Rubstov 1972). Areas which had been flooded with radium-containing water $(3000 \mathrm{pCi} / \ell)$ showed soils greatly enriched in radium compared with a control region (at least 70 times lower) and with a uranium-radium region (20 times lower); the radium was mostly confined to the top $25 \mathrm{~cm}$ in the flooded soil (Ovchenkov and Rubstov 1972). Tree species showed an acropetal gradient of radium activity in their tissues when growing in normal soils (Gruzdev and Rubstov 1972). Mountain tundra species had greater activities in their roots and stems than in their leaves; vegetables grown on soil enriched in radium $(100-1000 \mathrm{pCi} / \mathrm{g})$ had 1 to $13 \mathrm{pCi} / \mathrm{g}$ dry weight (Verkhovskaya, Vavilov, and Maslov 1972). For cultivated soddymeadow soil, Rusanove (1972) observed the reduction of radium mobility and uptake by plants from fertilizer and lime application but the increase of mobility after superphosphate application; for agronomic species growing in soils of high radium activity, a reduction in ac- 
tivity up to $27 \%$ was seen with use of nitrogen fertilizers (Vavilov et al. 1972a). For barley and winter rye growing under these conditions, the depression of chromosomal crossing-over and an increase in some chromosomal aberrations was reported (Vavilov et al. 1972b). The radium activity in lichens from different parts of the Soviet Union was 0.3 to $0.4 \mathrm{pCi} / \mathrm{g}$ (Nizhnikov et al. 1973). The normal radium activity of soils was 0.1 to $1.0 \mathrm{pCi} / \mathrm{g}$ for the USSR compared to 1 to $2 \mathrm{pCi} / \mathrm{g}$ for western Europe and a global average of $0.8 \mathrm{pCi} / \mathrm{g}$, the activity either decreases with depth (up to $100 \mathrm{~cm}$ ) or showed no change (Baranov and Morozova 1973). Thus, these diverse studies in the Soviet Union described the natural radiation background in plants and soils, contributed to radiogeological soil mapping, explored the influence of the natural radiation environment on living organisms, and evaluated the geochemistry of the soil and its plant cover in both natural and enhanced radium regions. The mobility and uptake of radium in diverse environments was documented.

A continuing area of research has been the comparison of radiation from different energy sources. Eisenbud and Petrow (1964) compared radium-226 activity in ash of coal (24 pCi/g) and of petroleum $(0.49 \mathrm{pCi} / \mathrm{g})$; they concluded that a coal-fired power plant discharged more radioactivity into the atmosphere than an oil-burning one and that a nuclear plant discharged less than either. Radium in coal was usually associated with the mineral content, overall, the coal contained 0.2 to $1.0 \mathrm{pCi} / \mathrm{g}$ while the mineral matter had $3.9 \mathrm{pCi} / \mathrm{g}$ (Pallister and Green 1964). Certain coal ashes have had elevated levels of radium $(6-8 \mathrm{pCi} / \mathrm{g})$ compared to coals (0.2-0.7 pCi/g) and British soils (0.5-0.8 pCi/g)(Gvozdanovic, Overton, and Spiers 1967).A series of investigations on radium activity in rural and industrial areas of Poland have been reported. Elevated soil (more than 10 times) and food activities (more than two times) were seen near a power plant compared to those in Warsaw (Pietrzak-Fils 1972). Elevated ash content and radium activities were also measured in snow near a power plant; both glacier ice and pine trees showed increasing radium activity over time (Jaworowski, Bilkiewicz, and Kownacka 1974). The top layer $(0$ to $5 \mathrm{~cm})$ of soils in industrial areas have elevated radium activity $(1 \mathrm{pCi} / \mathrm{g})$ compared to the next layer $(5-10 \mathrm{~cm})$ or to soils in non-industrial areas $(0.7$ to $0.8 \mathrm{pCi} / \mathrm{g}$ ); the highest surface soil activity was about $15 \mathrm{~km}$ from the power plant (Jaworowski and Grzybowska 1977). Natural radium-226 from soil dust and coal powef plants was shown to be a significant source for the contribution of radium into the lower troposphere (Moore and Poet 1976). Thus, the cycling of radium from power plants impacts the ecosystem in both terrestrial and atmospheric components and is a contribution to the radiation background.

Since early uranium mills were often situated adjacent to rivers, early studies of environmental impacts of these mills centered on aquailc effects. Many measurements were made on the Animas River in southwestern Colorado. Some radium-226 uptake by algae, insects, and fish was reported; crops downstream from the mill had twice as much radium as those upstream (Tsivoglou et al. 1960). Elevated radium activity was detected as much as 100 $\mathrm{km}$ downstream (Tsivoglou, Stein, and Towne 1960). A detailed study of the tailings from the mill on the Animas River showed the leachability of radium from those tailings (Shearer 1962; Shearer and Lee 1964). Other tailings were also surveyed for radium and gross alpha activity (Tsivoglou and O'Connell 1962). Later reports showed a reduction in bottom fauna, insects, and fish below the mill on the Animas River; however, the biomass and radium activity of algae increased below the mill (Anderson, Tsivoglou, and Shearer 1963). Soils irrigated with river water showed radium activities of 40 to $50 \mathrm{pCi} / \mathrm{g}$ and alfalfa grown on these soils had activities more than 100 times background; some elevated radium activity was measured in milk also (Tsivoglou 1964). The conclusions of these studies were that liquid wastes from uranium mills had radium-226 activities which were hazardous and that leaching of radium from solid wastes could be hazardous (Tsivoglou and O'Connell 1964).

Other investigations were conducted on aquatic species under varying conditions. After a 
release of uranium mill wastes, the radium activity of river silt and aquatic plants was measured; the silt contained 1-14 pCi/g and the plants, 11-12 pCi/g dry weight (Pendleton et al. 1964). The uptake of radium by a freshwater gastropod under experimental conditions showed similar behavior to calcium and strontium (Van der Borght 1963). Holtzman (1969) measured radium activity in several species of aquatic fauna and saw little difference between species. The recovery of the Animas River after the releases was surveyed and another river with a uranium mill was monitored for comparison (Martin, Helm, and Sigler 1969). In Czechoslovakia, water and algae were studied in two regions of uranium mining (Havlik 1970). Of five algal species studied, only two accumulated radium-226 (Havlik and Robertson 1971). The percentage of the measured radium activity within the cell (as opposed to on the surface) varied from more than $50 \%$ for two species to less than $10 \%$ for four species of algae (Havlik 1971).

Areas of high natural radioactivity due to the occurrence of uranium and thorium have been the focus of many studies in order to evaluate the radiation dose to man living in such areas. Some results on the Brazil nut trees in British Guiana showed elevated alpha activity in the nuts (Mercer, Mitchell, and Smith 1962). In two areas of Brazil with elevated radium-228 activity, grasses and bushes had high levels of radium content (Penna-Franca and Gomes de Freitas 1963). Food in both areas had higher radium content than that from a control area (Penna-Franca et al. 1965a, 1965b, and 1970). In Brazil nuts, total radium (radium-226 and radium-228) content was related to barium concentration and differed among plant parts with nuts having high activity and roots having low activity (Penna-Franca et al. 1968). An area of high radioactivity in India has been studied and compared with an area of background soil and regions of uranium mining; wide variations in plant and soil activities complicated any relationships between them and led to the conclusion that the leachability of radium-226 was an important parameter to study (Kamath et al. 1964). In the high radioactivity area of monazite sands, greater alpha and gamma activities were measured in perennials compared to annuals, in herbs compared to shrubs, and in leaves compared to other plant parts (Mistry, Gopal-Ayengar, and Bharathan 1965). These studies and concurrent radiographic and demographic surveys (Lovaas and Hursh 1968) contributed to the evaluation of effects of long-term exposure to elevated background radiation.

A wide variety of studies of radium-226 uptake by plants under experimental and natural conditions has been undertaken. Some studies used nutrient solutions spiked with radium. Peas grown in a solution containing $10 \mu \mathrm{Ci} / \ell$ had root activities twice as great as those of aerial parts (Kirchmann and Berino 1965). In a similar experiment, leaves had slightly higher activities than stems (Kirchmann, Roncucci, and Mousny 1965). Agronomic species grown in soil showed discrimination against radium in the transfer from soil to plant (Kirchmann, Boulenger, and Lafontaine 1968). The radium activity of 20 species growing on uraniferous lands in France was independent of the soil activity and of uranium absorption (Delpoux 1969). Plants growing at the site of an old radium factory had radium activities three to four times background and little surficial contamination; those growing in a contaminated drainageway at another site had lower activity (Kirchmann et al. 1973). The radium content of phosphate fert:lizers and its subsequent uptake by crops was also evaluated. Fertilizers contained from 20 to $40 \mathrm{pCi} / \mathrm{g}$ but significant plant uptake was predicted only after 50 years of crop production and little migration in the soil was expected (Kirchmann et al. 1977). Further studies with phosphates and phosphate fertilizers showed that straw had higher activity than grain (by 5 to 16 times); however, the fertilizer added only one percent or less of the radium activity in the top $20 \mathrm{~cm}$ of the soil (Kirchmann, Darcheville, and Koch 1980). Thus, many variations in radium uptake by plants from soils and nutrient solutions were seen in those studies.

A comparison of the uptake and translocation of radium with calcium, barium, and stron- 
tium was undertaken (Smith 1967). Two varieties of wheat from three regions in western Australia and Brazil nut trees from Guiana and Singapore were studied. The measured alpha activities in the plant tissues were due mostly to radium-226 and radium-228, but there was a poor correlation between the radium content in the exchangeable cation fraction and that in the plant tissue. The radium content was more closely related to barium than to strontium or calcium; for example, radium and barium were retained in the stem more than the other two elements. For wheat, the order of decreasing alpha activity was straw>young plant>grain>flour (Smith 1971a). In the Brazil nut tree the endosperm of the nut had the highest activities and the ratios of radium, barium, and strontium to calcium were 20 times greater than those for other tissues (Smith 1971b). Radium uptake has also been compared to the uptake of other radionuclides in the uranium series; radium uptake by roots of plants growing in nutrient solution was two to three times lower than that of the other nuclides, but its translocation to shoots is 50 to 200 times greater (D'Souza and Mistry 1970). Thus, the behavior of radium in the plant-soil system has been evaluated in terms of its similarity to other alkaline earth ions and other nuclides in the uranium series.

The radium uptake by plants has been related to other factors as well. In peas and barley grown in nutrient solutions, 30 to $70 \%$ more radium was absorbed at $\mathrm{pH} 4$ compared to $\mathrm{pH} 6$ (Gunn and Mistry 1970). When radium-226 and calcium-45 were added to three different soils, a strong discrimination against radium uptake compared to calcium was observed (Bhujbal, D'Souza, and Mistry 1972). A comparison of two meadow soils, one normal and one flooded from uranium processing, was made; the activity of the flooded soil was 10 to 30 times that of normal soils and the plants growing in it had activities 5 to 10 times normal (Wlodek, Grzybowska, and Bysiek 1970). The rao: $1 \mathrm{~m}$ activity of plants growing in a sandy soil, with lower organic matter, was greater than that of a humus soil (Grzybowska and Wlodek 1972). After measuring the radium activity of higher vegetation, which averaged about $0.7 \mathrm{pCi} / \mathrm{g}$, it was concluded that the radium associated with dust in precipitation could be an important factor in the activity of plants (Grossman, Kwapulinski, and Rukasik 1973). A decrease in radium activity of alfalfa and rye grass biomass over the growing season was seen in plants growing in three soils (Grzybowska 1974). Thus, many diverse studies contributed to conclusions about plant uptake of radium: the radium activity of roots was generally 10 to 100 times that of shoots, the uptake was greater in soils of lower organic matter content and cation exchange capacity, and the radium activity of agronomic species decreased over the growing season.

Studies from other environments were comparable to those from the vicinity of uranium mills. An area of high natural radioactivity in Iran was reported to have soil activities (17-9000 $\mathrm{pCi} / \mathrm{g}$ ) comparable to those of tailings; plants in the area had radium activities of 0.02 to 36 pCi/g (Khademi, Alemi, and Nasseri 1980). Soils and tailings from areas of phosphate mining were seen to have elevated radium activities by at least a factor of 10 (Roessler et al. 1980), because phosphates range in activity from 1 to $130 \mathrm{pCi} / \mathrm{g}$ (Menzel 1968). Anomalous concentrations of radium in water (3-11 pCi/l) were found in Oklahoma; vegetables canned using this water had significantly higher radium activity (Keefer and Fenyves 1980). The behavior of radium in the environment was a factor in all of these studies. For reference, the uranium238 decay series is given in Figure 7. 


\section{URANIUM SERIES (minor branches not shown) MAJOR RADIATION ENERGIES (MeV) AND INTENSITIES (percentage of disintegrations) NUCLIDE (HALF - LIFE) \\ ALPHA \\ BETA}

$4.15(25)$

$4.20(75)$ 2sish (24d)

$25 \mathrm{Po}(1.2 \mathrm{~m})$

$22 y\left(2.5 \times 10^{9} y\right)$

2 The $\left(8.0 \times 10^{4} y\right)$

22mo (1602y)

$202 R_{n}(3.8 d)$

24 po $(3.0 \mathrm{~m})$

$214 \mathrm{pb}(27 \mathrm{~m})$

2148I (20m)

214po (164,s)

201po (22y)

2401 (5.0d)

21po (138d)

2mpb (stablo)
0.10
0.19 $\left(\begin{array}{ll}21 \\ 79\end{array}\right) \quad 0.06\left(\begin{array}{l}3 \\ 4\end{array}\right)$

2.29 (98) $\quad \begin{array}{ll}0.77(0.3) \\ 1.00(0.6)\end{array}$

$4.72\left(\begin{array}{l}28 \\ 72\end{array}\right)$

$4.62(24)$

$4.68(76)$

$4.60(6)$

4.78 (95)

$0.05(0.2)$

$0.07(0.6)$

$0.14(0.1)$

0.19 (4)

$5.49(100)$

$0.51(0.1)$

$6.00(100)$

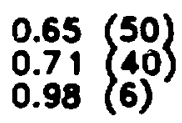

$0.30(19)$

$0.35(36)$

$1.00(23) \quad 0.61$ (47)

$1.51(40)$

3.26 (19)

$7.69(100)$

0.02
0.06 $\left(\begin{array}{l}85 \\ 15\end{array}\right)$

$0.05(4)$

\section{$5.31(100)$}

Figure 7. Decay series of uranium-238. 